Portland State University

PDXScholar

10-30-1989

\title{
An Analysis of US/Soviet Arms Control: Adding a Subsystem Perspective
}

Peter Millard Olson

Portland State University

Follow this and additional works at: https://pdxscholar.library.pdx.edu/open_access_etds

Part of the International Relations Commons

Let us know how access to this document benefits you.

\section{Recommended Citation}

Olson, Peter Millard, "An Analysis of US/Soviet Arms Control: Adding a Subsystem Perspective" (1989). Dissertations and Theses. Paper 4300.

https://doi.org/10.15760/etd.6185

This Thesis is brought to you for free and open access. It has been accepted for inclusion in Dissertations and Theses by an authorized administrator of PDXScholar. Please contact us if we can make this document more accessible: pdxscholar@pdx.edu. 
AN ABSTRACT OF THE THESIS OF Peter Millard Olson for the Master of Arts in Political Science presented October $30,1989$.

Title, An Analysis of US/Soviet Arms Control, Adding a Subsystem Perspective.

APPROVED BY THE MEMBERS OF THE THESIS COMMITTEE.

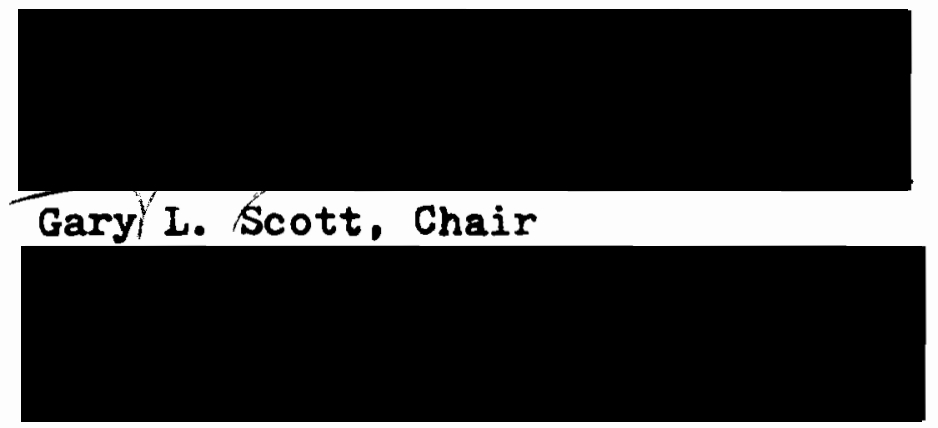

Ladis K.D. Kristof

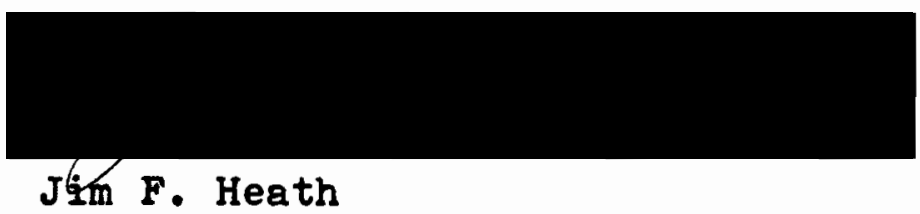

Analyses of US/Soviet arms control have usually focused on domestic variables to explain US/Soviet arms control behavior. Partly because the number of negotiating parties is only two, there is a propensity to focus on the bilateral relationship of the United States and the Soviet Union and their respective domestic political situations. Only superficial attention has usually been 
given to international systems variables that may well influence the donestic political situation and arms control policy.

This thesis broadens the explanatory scope of US/Soviet arms control by showing how the political environment of a trilateral relationship (a subsystem that includes the West European members of NATO as a single actor as well as the United States and the Soviet Union) is a primary motivator of US/Soviet arms control behavior.

Three main reasons are given as to why this particular subsystem is an important determinant in US/Soviet arms control. First, arms control is a security issue. It involves both defense and deterrence.

Secondly, each actor in the subsystem plays an important security role, either as adversary or alliance partner, or both. Certain assumptions of behavior are accordingly ascribed to each actor. Alliance unity and alliance reassurance then become part of the overall security equation.

Third, Western Europe has played an increasingly influential role in US/Soviet arms control due to its geo-strategic position between the two superpowers, its growing economic position in the international arena, and the attainment of nuclear parity between the United States and the Soviet Union. Greater attention is now given to two additional factors, West European security concerns of "entrapment" in a nuclear war as a result of superpower 
conflict, and, U.S. "abandonment" of its military commitment to protect Western Europe as a result of superpower cooperation.

The chapters of this thesis present an inquiry into certain domestic determinants of US/Soviet arms control behavior in three arms control regimes (SALT I, SALT II, and INF/START), followed by observations that support and emphasize the explanatory influence of the subsystem perspective.

Utilizing "events-data" analysis and the New York Times Index, quantitative data is presented as additional support for the subsystem perspective.

For each arms control regime analyzed, it is concluded that US/Soviet arms control is influenced by the interaction of the adversary/alliance subsystem relationships. The resultant political environment of this subsystem affects US/Soviet arms control, and influences the domestic determinants of arms control as well. In part, SALT I negotiations were motivated by Western security perceptions, particularly among West Europeans, that sought an end to the Cold War relations by promoting East/West cooperation. The results were the treaties of SALT I and the codification of detente. By the latter 1970s, however, NATO perceptions of security had changed, focusing on the need for new weapons deployments in lieu of arms control. SALT II was doomed, in part by criticism 
at home and in Western Europe, that it failed to address the perceived imbalance in theater nuclear forces.

The INF/START negotiations in the early 1980s

reflected another change in NATO security perceptions. This time cruise and Pershing II missiles would be deployed in Western Europe but would be coupled with arms control negotiations. The "dual track" decision was not so much a bargaining chip tactic to achieve reductions in Soviet missiles as it was a demonstration of NATO ambivalence over Western security policy. The "dual track" decision was designed both to reduce West European concerns of entrapment, via arms control, and to reduce West European fears of abandonment via arms deployments. 
AN ANALYSIS OF US/SOVIET ARMS CONTROL:

ADDING A SUBSYSTEM PERSPECTIVE

by

PETER MILLARD OLSON

A thesis submitted in partial fulfillment of the requirements for the degree of

MASTER OF ARTS

in

POLITICAL SCIENCE

Portland state University

1989 
TO THE OFFICE OF GRADUATE STUDIES :

The members of the Committee approve the thesis of Peter Millard Olson presented October 30, 1989.

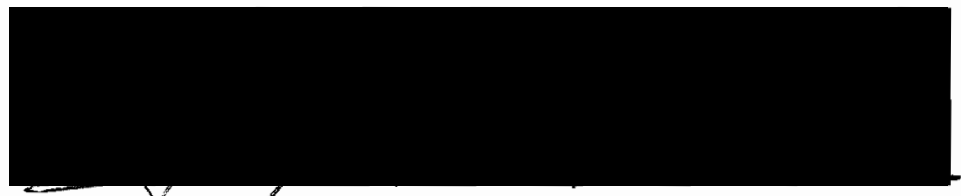

Gary I. Scott, Chair

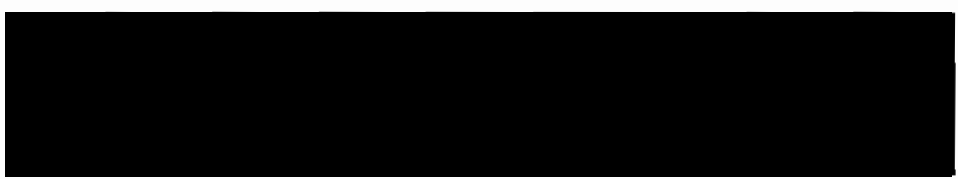

Ladis $K \circ D$ o Kristof

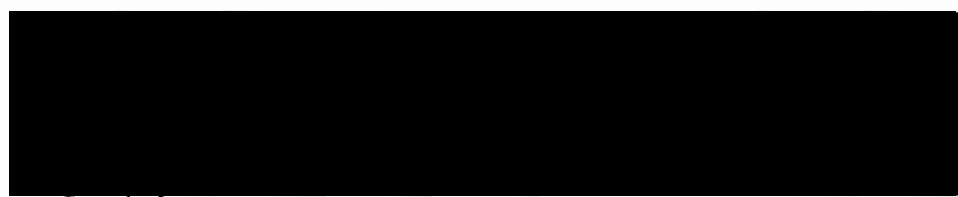

Jimlf. Heath

APPROVED,

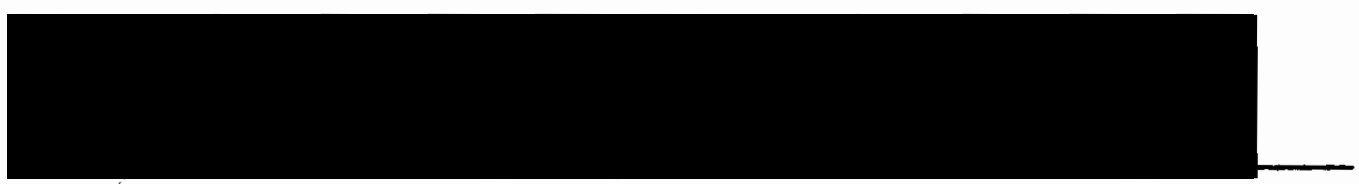

Gary I. Scott, Chair, Department of Political Science

C. William Savery, Interim Vice Provost for Graduate Studies and Research 
TABLE OF CONTENTS

PAGE

LIST OF TABLES

vi

LIST OF FIGURES . . . . . . . . . . . . . . . . . . . vii

\section{CHAPTER}

INTRODUCTION . . . . . . . . . . . . . . .

Overview of Goals . . . . . . . . . . 1

The Subsystem Model . . . . . . . . 2

Assumptions of Behavior . . . . . . . 5

Methodology and Research Data . . . 8

Chapter I Notes . . . . . . . . . . 13

II SALT I . . . . . . . . . . . . . . . 16

The Issues of SALT I . . . . . . . . 16

The Political Leader Characteristics

Variable... . . . . . . . . 23

The Nixon Administration: Personal Attitudes

Participation

Scope of Authority

Election Year Politics

Nixon and SALT I

Analyzing Soviet Politics

The Brezhnev Regime

Brezhnev and SALT I

The Subsystem Variables . . . . . . 36

Conclusion . . . . . . . . . . . 46

Chapter II Notes... . . . . . . . 49 
III SALT II . . . . . . . . . . . . . 54

The Issues of Salt II . . . . . . . . 54

The Political Leader Characteristics

variable............ 61

Nixon (1973-1974)

The Ford Administration

The Carter Administration

Carter and SALT II

Failure to Ratify SALT II

Brezhnev (1973-1979)

Brezhnev's Detente Policy

Brezhnev and SALT II

The Subsystem Variables . . . . . . 76

The Test of Detente

Changed West European Security

Concerns

Soviet and U.S. Reaction

The Decline of Detente

Conclusion . . . . . . . . . . . 87

Chapter III Notes . . . . . . . . 91

IV INF/START . . . . . . . . . . . . . . . 97

The Issues of INF/START . . . . . . . . 97

INF

START

The Political Leader Characteristics

Variable . . . . . . . . . . 110

The Reagan Administration

Personal Attitudes

Participation

Scope of Authority

Transition in Soviet Leadership

Soviet Policy in INE/START

The Subsystem Variables . . . . . . 119

Changed Security Perceptions

U.S. and Soviet Reaction

West European Reaction

The Issue of Deployment 


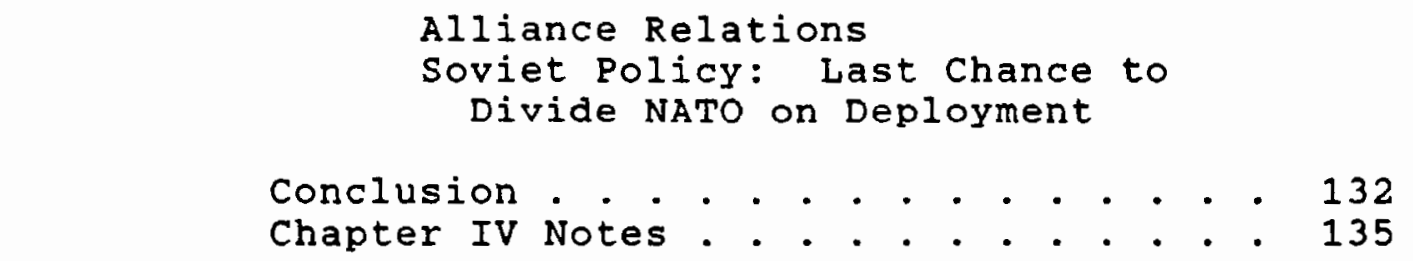

v. CONCLUSION . . . . . . . . . . . . . . 140

Research Summary . . . . . . . . 140

Policy Implications . . . . . . . 141

Future Arms Control Negotiations. . . 144

Chapter V Notes . . . . . . . . . . 147

SOURCES CONSULTED . . . . . . . . . . . . . . . . . 149

APPENDIX . . . . . . . . . . . . . . . . 161 


\section{LIST OF TABLES}

TABLE

PAGE

I SALT I SUBSYSTEM DATA 1969-MAY 1972 • • • 162

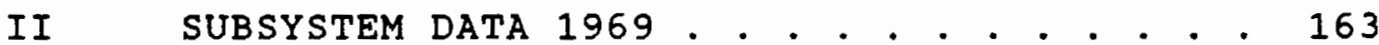

III SUBSYSTEM DATA 1970 . . . . . . . . . 164

IV SUBSYSTEM DATA 1971 . . . . . . . . . 165

V SUBSYSTEM DATA THRU MAY 1972 . . . . • . 166

VI SALT II SUBSYSTEM DATA 1973-1979 . . . . . 167

VII SUBSYSTEM DATA 1973 . . . . . . . . . . 168

VIII SUBSYSTEM DATA 1974 . . . . . . . . . . 169

IX SUBSYSTEM DATA 1975 . . . . . . . . . 170

X SUBSYSTEM DATA 1976 . . . . . . . . . . . 171

XI SUBSYSTEM DATA 1977 . . . . . . . . . 172

XII SUBSYSTEM DATA 1978 . . . . . . . . . 173

XIII SUBSYSTEM DATA 1979 . . . . . . . . . . 174

XIV INF/START SUBSYSTEM DATA $1980-1983$ • . . . 175

XV SUBSYSTEM DATA 1980 . . . . . . . . . . 176

XVI SUBSYSTEM DATA 1981 . . . . . . . . . . 177

XVII SUBSYSTEM DATA 1982 . . . . . . . . . . 178

XVIII SUBSYSTEM DATA 1983 . . . . . . . . . 179 


\section{LIST OF FIGURES}

FIGURE

PAGE

1. The Subsystem Model . . . . . . . . .

2. Graph Showing Percent Positive in

Subsystem Relationships . . . . . . . 11

3. Graph of President Nixon's Popularity . . . 28 
CHAPTER I

INTRODUCTION

OVERVIEW OF GOALS

The basic purpose of this study's examination of US/Soviet arms control is to broaden the analytic scope of this issue. ${ }^{1}$ Analyses of US/Soviet arms control have usually focused either on the domestic political situation of the United States or the Soviet Union, or have emphasized comparisons of their domestic policies in explaining arms control behavior. The wide range of literature on this issue has generally given only perfunctory attention to international system variables that may well influence the domestic political situation and arms control policy. ${ }^{2}$

The perfunctory attention given to international system variables in analyses of US/Soviet arms control is partly because of an assumption based in the bilateral nature of formal negotiations. Since the number of negotiating parties is limited to two, there is a propensity to focus solely on the foreign policymaking of those two parties. Such approaches are highly applicable, yet they are not without limitations. ${ }^{3}$ The actions of one state that affect its relations with another state are not made in 
total isolation from the rest of the international system. Therefore, it is quite possible to enhance our understanding of certain foreign policy behavior by including relevant international system variables. ${ }^{4}$ In order to demonstrate the importance of including relevant international system variables in US/Soviet arms control analyses, three arms control regimes have been chosen for examination. They are SALT I (Strategic Arms Limitation Talks), SALT II, and INF/START (Intermediate Nuclear Forces and Strategic Arms Reduction Talks).

THE SUBSYSTEM MODEL

Citing international system variables that may influence US/Soviet arms control is not a difficult task given the highly interactive nature of world politics. However, because arms control is a security issue, ${ }^{5}$ it is essential that the criteria in choosing relevant international system variables for examination are those which have the most direct influence on U.S. and Soviet security, and those that are most directly affected by US/Soviet arms control. The variables chosen for this study are the US/Soviet relationship, the US/West European relationship, and the West European/Soviet relationship. 6

These three dyads form a trilateral subsystem ${ }^{7}$ in which Western Europe, ${ }^{8}$ though not a direct party to the US/Soviet arms control treaties or negotiations chosen for 
examination, does have a significant influence on arms control behavior by virtue of its position as alliance partner with the United States, its geo-strategic position between the United States and the Soviet Union, its growing economic influence in the world, and the attainment of nuclear parity between the two superpowers (see Figure 1). Following World War II the security of Europe was linked to the security of the United States by extending the U.S. nuclear deterrent to its West European allies. At that time U.S. hegemony over the alliance was an accepted fact as was the credibility of the United States to deter Soviet aggression against Western Europe. "Massive Retaliation" was a credible policy of deterrence as long as the United States could strike the Soviet Union without risking a reciprocal strike. The "decoupling" effects of nuclear parity was not a foreseeable problem in the earlier years of the alliance, but fostered by the post-war economic recovery of Western Europe and intensified by the attainment of strategic parity between the superpowers, the security concerns unique to West Europeans have been expressed with an increasingly more independent and confident voice. Accordingly, these concerns are translated into political leverage over the arms control positions of the two superpowers. With both the United States and the Soviet Union seeking to accommodate the West Europeans, the junior alliance partner thus acquires indirect, though highly 


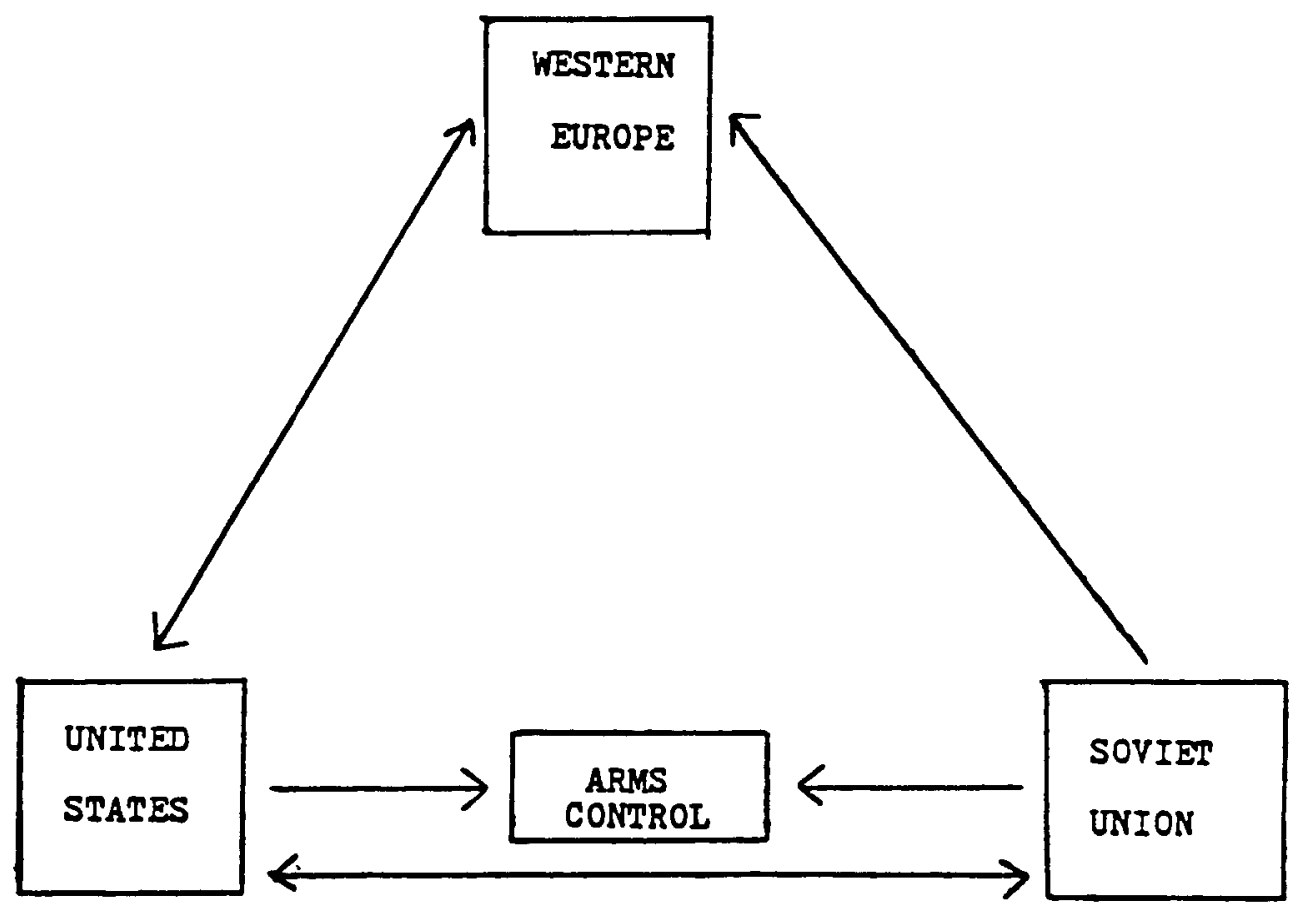

Figure 1. The subsystem model. 
influential bargaining power in arms negotiations. It is the changes in west European security concerns and the effects of those changes on the subsystem relationships that are important in explaining the success or failure of US/Soviet arms control.

\section{ASSUMPTIONS OF BEHAVIOR}

The role of each actor within the subsystem allows certain assumptions to be made regarding their behavior toward one another.

The US/Soviet relationship, characterized as adversarial, is such that each perceives the other as the main threat to its own security. As security enhancing measures each attempts to undermine the security of the other and maintain a credible deterrence against the encroachment of its own security. The unity of Nato (North Atlantic Treaty organization) is perceived by the United States as essential to its deterrence of the Soviet Union.10 The Soviet Union perceives alliance unity as a threat to its own security. Therefore, Soviet arms control policy will attempt to divide the alliance whereas U.S. arms control policy will attempt to unify it.

The US/West European relationship is characterized by partnership in military alliance (NATO). The alliance is characterized by common security but it is also characterized by distinct security concerns. It is these 
individual concerns about security that can cause tensions between the alliance partners.

Similar to the "abandonment-entrapment dilemma" discussed by Robert Osgood, alliance tensions can be caused by adversary cooperation or by adversary conflict.11 West European concerns may be heightened if U.S. bilateral agreements with the Soviet Union are perceived as evidence of American abandonment of Western Europe. On the other hand, concerns may rise if us/Soviet conflict (i.e., nuclear arms racel is perceived as leading to entrapment in a superpower inflicted war. Thus, Western Europe may encourage a US/Soviet rapprochement in order to reduce the risks of entrapment, but may then criticize the United States and/or the Soviet Union if the trend of adversary cooperation begins to show signs of abandonment.

As Jane Sharp has suggested, this relationship should be viewed as circular rather than linear, as a cycle which may begin by Western Europe seeking reassurance from the United states due to anxiety causing events.12 The United States then responds with reassurance in the form of consultations, new weapons for NATO defense, or a tougher policy toward arms control. The West Europeans then encourage a renewed superpower attempt at cooperation, which, if further bilateral agreements are generated, may induce new fears of abandonment.13

The West European/Soviet relationship includes the 
abandonment-entrapment concerns of western Europe and the adversarial characteristic of that relationship. The soviet Union, through policies of cooperation or conflict toward Western Europe, may attempt to divide the alliance. Western Europe may promote cooperation or conflict between the United states and the Soviet Union depending upon its own security concerns. Western Europe may also choose policies of cooperation or conflict with the Soviet Union depending upon its perceptions of U.S. abandonment and/or superpower entrapment.

The arms control policies of the United States and the Soviet Union are, therefore, affected by the trilateral relationships of the subsystem. By examining these relationships and US/Soviet arms control over specific time periods, it should be possible to suggest in which instances the subsystem variables had more influence on arms negotiations than the domestic perspective.

There are questions that might be raised to compare the domestic and subsystem approaches. For example, should the motivation by the United states and the Soviet Union to pursue SALT I be regarded more as policy goals characteristic of the Nixon administration and the Brezhnev regime, or should the stimulus to negotiate be viewed more as a result of systemic pressures on the United States and the Soviet Union? Were the failure of the U.S. Senate to ratify the SALT II Treaty and the NATO decision to deploy 
cruise and Pershing II missiles in western Europe primarily due to political features of the Carter administration and/or Soviet policies, or were they consequences of a larger political environment in which Western Europe had become more openly disconcerted over a us/soviet condominium that sacrificed West European security? Was the collapse of the INF/START talks in 1983 due to Andropov's waning political power, soviet domestic problems, and the antiSoviet ideology of the Reagan administration, or in the systemic view, was the soviet walkout part of a consistency in Soviet policy--the use of arms control to drive a political wedge between the United States and Western Europe?

There are, of course, no black and white answers.

This is true in part because the explanations are colored by the characteristics of both perspectives. This study is not predisposed toward any single-dimension approach to the study of arms control, but it is critical of comparative research that excludes international system variables as explanatory possibilities.

\section{METHODOLOGY AND RESEARCH DATA}

The time frame covered in this study is from 1969 through 1983. This period coincides with events surrounding three arms control regimes--SALT I, SALT II, and INF/START. Each of the three subsystem relationships is observed over 
each period of arms control so that conclusions can be made regarding the association between these variables and arms control behavior.

Measurement of each variable is accomplished by the use of "events-data" analysis.14 The relevance of this method is that it utilizes behavior as the unit of observation. Events are transformed into data according to the type of behavior they represent.15 Each variable is characterized by its behavior classification, derived from a set of events observed over a specific time period. Because the chronology of events is retained in the analysis of the data, and because the data are classified by type and frequency, this methodology also allows for the use of some quantitative analytic procedures.

Data has been collected for each subsystem relationship, then coded according to its behavior type. For both the US/Soviet and the West European/Soviet relationships, behavior is classified into a conflict/cooperation typology. Events are coded according to the degree of cooperation or conflict they reflect. The US/West European relationship is coded somewhat differently. A unity/disunity typology is used and events are coded by the degree to which they reflect unity or disunity in the alliance relationship.

Following the collection and coding of data for each variable, simple quantitative analytic techniques have been 
employed. These techniques organize the data into frequency and percentage tables for general and more specific time periods of arms control (see Appendix). These tables show both the frequencies of behavior across time and the distribution of behavior classifications across time for each subsystem variable. The percent positive for each relationship has been graphically illustrated (see Figure 2). Conclusions can then be based on the observed association between arms control behavior and the subsystem variables, both in the aggregate and for more specific time periods.

In addition to the subsystem approach, an internal variable has been observed for the same time period. Labeled the Political Leader Characteristics Variable, it measures certain aspects of the domestic political situation of both the United States and the Soviet Union which have been deemed relevant in influencing arms control. This variable capsulizes Margaret Hermann's model, the "Leadership Characteristics Variable," into three categories: "Personal Attitudes"; "Scope of Authority"; and "Participation."16 These categories represent characteristics of the political leader, not just those he personally provides (e.g., ideology) but also those created by his political position as head of a particular political system.

"Personal Attitudes" refers to the leader's unique 


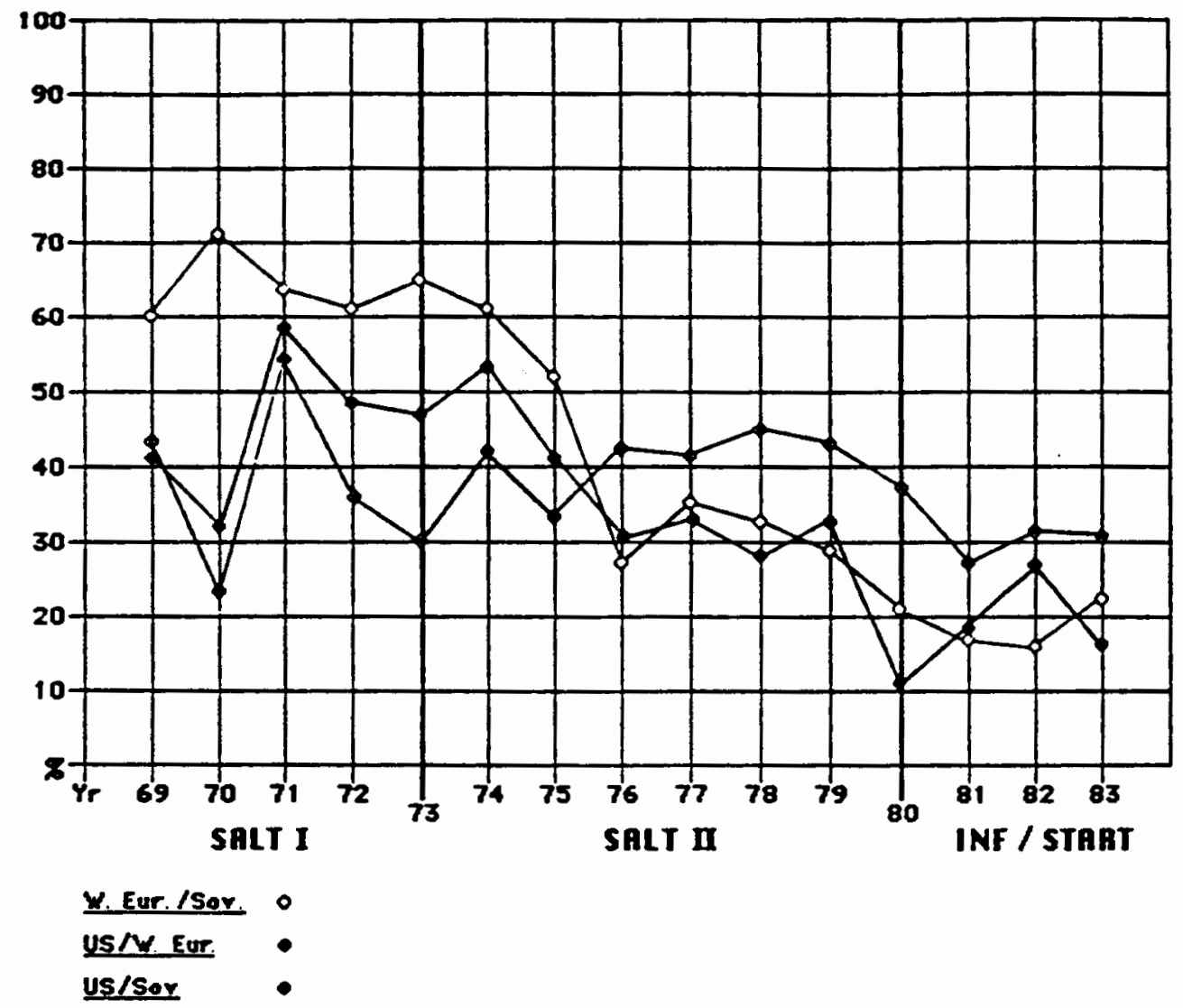

Pigure 2. Graph showing percent positive in subsystem relationships. 
political style, his personal beliefs, and personal views of the world.

"Scope of Authority" refers to the political leader's latitude in decisionmaking. Does he have the support of Congress? Of the public? How constrained is he in his immediate decisionmaking role? In the case of the American leader, this is measured by the margin by which he was elected, by public approval in reliable surveys, and by the percent of his party's constituency represented in congress. In the case of the soviet leader, scope of authority is measured by the degree to which he dominates decisionmaking in the Politburo, and the relative ease with which his policy goals are implemented and carried out.

"Participation" refers to the amount of attention the leader gives personally to foreign policy, particularly arms control. This not only involves his personal interest in arms control but also the degree to which he delegates his authority to his subordinates or relies on others in his decisionmaking.

Although this variable does not encompass other domestic political factors, it does cover the most relevant and accessible in regards to arms control policymaking. 


\section{CHAPTER I NOTES}

${ }^{1}$ For analytical purposes of this study arms control is defined as: arrangements between the United States and the Soviet Union to limit and/or reduce their nuclear force structures. Both states' behavior towards arms control include: the motivation of either side to pursue arms control agreements; their negotiating positions; proposals and rejections of proposals, and; reasons for agreements or failure to reach agreements.

${ }^{2}$ A few recent examples include, Thomas $W$. Wolfe, The SALT Experience (Cambridge: Ballinger Publishing Co.. Inc., 19791: Frank Whelon Wayman, "Arms Control and Strategic Arms Voting in the U.S. Senate," Journal of Conflict Resolution (Vol. 29, No. 2, June 1985); Myron Hedlin, "Moscow's Line on Arms Control," Problems of Communism (May/June 1984); and Strobe Talbott, Deadly Gambits (New York: Alfred A. Rnopf, 1984).

${ }^{3}$ For an excellent discussion of the advantages and limitations of various comparative foreign policy approaches see, Maurice A. East, Stephen A. Salmore, and Charles F. Hermann, eds., Why Nations Act (Beverly Hills: Sage Publications, 1978).

4 For an excellent analysis of international system variable influence on foreign policy see, Gary L. Scott and Takashi Shinobu, "Reassessing the Japan-China Peace and Friendship Treaty Negotiations: A Comparative Foreign Policy Perspective," Journal of Northeast Asian Studies (Vol II, No. 4, December 1983).

${ }^{5}$ The term security is a highly ambiguous and thus controversial concept. For purposes of this study, security refers to the military defense of a state or the ability to deter an adversary. The necessary security requirement of a. state and the perceptions of threats to that security are determined by the political leaders of that state.

6other international system variables that may influence US/Soviet arms control such as Japan, China, and the Warsaw Pact do not fit the criteria as neatly as Western Europe. Japan, although a major economic power and included under the U.S. nuclear umbrella, is not a military alliance partner with either the United States or the Soviet Union. The Warsaw Pact, an alliance of East Bloc countries, may influence US/Soviet arms control. However, independence in foreign policymaking is far more subordinate to soviet policy than West European policymaking is to United States 
policy. Additionally, information regarding policy process is highly inaccessible.

However, other analyses of US/Soviet arms control

which include these or other international system variables are encouraged since they further a broader understanding of US/Soviet arms control and the development of multicausal theory.

${ }^{7}$ A subsystems approach adheres to the same theoretical views of a systems approach, although it delineates a particular subset of the international system for examination. For further discussion and references of the systemic perspective in international relations theory see, for example, Maurice A. East, "The International system Perspective and Foreign Policy," in East, et al., Why Nations Act, pp. 143-160; "Systemic Theories of Politics and International Relations," in James $\mathrm{E}$. Dougherty and Robert L. Pfaltzgraff, Jr., Contending Theories of International Relations (New York: Harper and Row, 1981), and; Richard Little, "A Systems Approach," in Trevor Taylor, ed.. Approaches and Theory in International Relations (London: Longman Group Limited, 1978), pp. 182-204.

${ }^{8}$ Another aspect of the subsystem model must be clarified. This is the theoretical treatment of western Europe as a single political actor. While this may present real problems in practice, it is most appropriate to the approach of this study. The level of analysis from which arms control is examined utilizes Western Europe as a single unit, as an alliance partner, and thereby posits a distinct set of theoretical questions.

9The verb "decouple" is a term applied in alliance and deterrence theory. In the context of NATO and the extended deterrent of the United States to Western Europe, the decoupling effect refers to the splitting up of alliance partners due to the lack of credibility of extended deterrence in a political environment characterized by strategic parity between the superpowers.

${ }^{\circ}$ For a thoughtful discussion on this point see, for example, Michael Howard, "Reassurance and Deterrence: Western Defense in the 1980s," Foreion Affairs (Vol. 61, 1983), pp. 309-324.

1'See, Robert E. Osgood, The Entangling AIliance (Chicago: University of Chicago Press, 1962). For further discussion see, for example, Glen H. Snyder, "The security dilemma in alliance Politics," World Politics (No. 36, July 1984). 
12 See, Jane M.O. Sharp, "Arms Control and Alliance Commitments," Political Science Quarterly (Vol. 100, No.4, Winter 1985-1986).

${ }^{13}$ Ibid., pp. 651-652.

${ }^{14}$ For a discussion of the techniques of events-data analysis see, for example, Charles A. McClelland, et al., The Communist Chinese Performance in Crisis and Noncrisis: Quantitative studies of the Taiwan straits confrontation, 1950-1964 (U.S. Naval Ordnance Test Station, China Lake, Ca., 1967); and Charles A. McClelland and Gary Hoggard, "Conflict Patterns in the Interaction Among Nations," in James N. Rosenau, ed., International Politics and Foreign Policy (New York: Free Press, 1969). This study follows Mcclelland's method, although a variation in the coding of events has been adapted to meet the peculiarities of this study. This analysis utilizes the New York Times Index as its source. I must note that by relying on a single source for my data I risk some degree of validity. This I have opted to do in the interest of time and simplicity.

${ }^{13}$ The definition of an "event" is borrowed from the CREON Project (Comparative Research on the Events of Nations). Unpublished Manuscript, p. 34.". . . a minimally aggregated action resulting from a decision by the political authorities of a state, who have the power to commit the resources of the national government." An event consists of an actor, an action, and the direct object or indirect object of that action.

16 The characteristics of this variable are taken mainly from the leader personality perspective discussed by Margaret Hermann in "Effects of Personal Characteristics of Political Leaders on Foreign Policy," in East, et al., Why Nations Act, pp. 49-68. 


\title{
CHAPTER II
}

\author{
SALT I \\ THE ISSUES OF SALT I
}

The issues and events associated with the negotiation of SALT I begin with the opening meeting between the U.S. and Soviet delegations in Helsinki in November 1969 and end with the signing of the SALT agreements in Moscow on 26 May 1972. This period covers the seven rounds of talks between the two delegations, alternating between Helsinki and Vienna; the so-called "back channel" negotiations between higher officials of both governments; and the climactic summit meeting between President Nixon and General Secretary Brezhnev, during which the final details of the agreements were worked out. The following is a summary of the key issues of SALT I.1

Aside from the agreements signed in 1971, to reduce the accidental occurrence of nuclear war and to upgrade the communications link between the two countries, SALT I produced two separate agreements on the limitation of strategic weapons systems. These were the ABM Treaty, a limitation on Antiballistic Missile systems, and the Interim 
Agreement on Strategic offensive Weapons. The latter agreement, however, was limited to missile launchers.

Although these agreements marked a real achievement in the progress toward mutual arms reduction, they demonstrated only moderate results from what began as much broader objectives; from the total banning of ABMs to a comprehensive limitation and reduction of both offensive and defensive systems, including Forward-Based systems (FBS), and Multiple Independent Re-entry Vehicles (MIRVs).

The first round of talks in Helsinki was considered an exploratory meeting, open to discussion on any related issue. The Soviets immediately took the opportunity to raise the question of American FBS, those weapons systems deployed in forward bases around Western Europe. ${ }^{2}$ This issue opened the way for debate over the definition of tactical versus strategic weapons, a debate that became a major obstacle to any comprehensive treaty limiting offensive weapons. The Soviets opposed any freeze on their European targeted Intermediate and Medium-range Ballistic Missiles (IR/MRBMs), labeling them tactical (incapable of striking the U.S. mainland), but insisted on including in a treaty the "strategic" Forward-Based Systems of the United States (capable of striking the Soviet Union). On the other hand, the United States defined its FBS not by whom or what they were targeted at, but by their range capability. Thus, 
only American systems capable of intercontinental range were deemed strategic.

It was not until late in the second round of talks in Vienna (August 1970) that the first real proposals toward a treaty were offered by either side. The U.S. proposal became known as the "Vienna Option." This proposal, actually a modification of three slightly different approaches, limited launchers of both sides, put a subceiling on Soviet ss-9 launchers, and established a freeze at current levels on strategic bombers, IR/MRBMs, and Submarine Launched Cruise Missiles (SLCMs). References to MIRVs included either total banning of flight testing and deployment, or no limitation coupled with incremental reductions in launchers for Intercontinental Ballistic Missiles (ICBMs) and Submarine Launched Ballistic Missiles (SLBMs). ABMs would either be limited to one site for each country to defend its National Command Authority (NCA), or they would be completely banned. Any treaty would be comprehensive, considering offensive and defensive systems together. A Soviet proposal called for joint retaliation against any country launching a provocative attack against either party. Neither proposal was well received.

The third round of talks in Helsinki was relatively passive in that the United States held to the Vienna Option, insisting that the soviets respond to it. The soviets continued their arguments to include FBS. In December 1970 
the soviets tabled their FBS "Compensation Proposal" which was, according to them, an attempt to compromise on the FBS issue. ${ }^{3}$ This meant a partial rather than complete withdrawal of U.S. Forward-Based Systems, but to be accompanied by a reduction in U.S. strategic launchers--the launcher reduction being compensation for any remaining FBS. Rejecting this proposal, the United States then offered the so-called "Helsinki Formula" by which the United states would consider the FBS issue only after all the main elements of an initial agreement on central strategic systems had been worked out. ${ }^{4}$ The soviets, however, were not interested.

Near the end of this round a private proposal was made by the head of the soviet delegation for a mutual no first use of nuclear weapons. This, too, was unacceptable for the United states. Also in December the soviets directed the negotiations away from a comprehensive agreement by proposing their "Basic Provisions for an Agreement on Limiting Deployment of ABM systems." This called for a singling out of the $A B M$ issue and negotiating a separate agreement. The "Provisions" included one ABM site to defend launchers, missiles and radars; a limitation on the radius of defense around each capital, and; equal numbers of launchers and missiles. Retreating somewhat from its position in favor of a comprehensive offensive/defensive 
treaty, the United States did not reject the proposal outright but left it open for further discussion.

The fourth round of talks began in March 1971. While the delegations made little progress in vienna, the focus of the negotiations had transferred to "backchannel" meetings. Talks between National Security Advisor Kissinger and Soviet Ambassador Dobrynin led to an exchange of letters between President Nixon and Soviet Premier Kosygin. This became known as the May 1971 Accord. It also marked a turning point in the U.S. position. By "agreeing to agree" to focus on ABM limitations the United States was abandoning its comprehensive treaty position in favor of negotiating a defensive treaty separate from an offensive one. Both sides also narrowed their objective for a moratorium or freeze approach to offensive weapons. But the United States had not excluded offensive freeze limitations altogether. Rather, it insisted on a freeze in conjunction with an $A B M$ agreement. The Soviets, however, refused to negotiate a freeze until an ABM treaty was reached. Both the fourth round of talks and the following round in Helsinki subsequently focused on negotiating an $A B M$ treaty.

Progress was made on $A B M$ issues, while offensive freeze negotiations remained stalled. The fifth round, from July to september 1971, produced the first real results of SALT--the Joint Draft Text of an ABM Agreement. Then on October 12 President Nixon announced his decision to go to 
Moscow the following spring. This set a deadline of sorts and quickened the pace for progress in negotiations, which resumed for a sixth round in November.

In Vienna talks continued on unagreed items of the $A B M$ treaty while discussions on an offensive freeze were revived. Still opposing the inclusion of SLBMs, the soviets tabled a freeze proposal halting new ICBM development and deployment beginning $1 \mathrm{July} 1972$, or at such time the treaty would take effect. A freeze on new ICBM launchers following the signing of the treaty was acceptable to the United states, but only on conditions which allowed some modernization and replacement of outdated systems.

By March 1972, as the seventh round of talks proceeded in Helsinki, an agreement on ABMs was nearing its final stages. Talks on an interim freeze on offensive weapons were also progressing. The remaining issues of the $A B M$ treaty were narrowed to numbers, how many sites and where, how many launchers and interceptor missiles, and how many radar components. Negotiations on the interim freeze continued over the SLBM debate, a ceiling on "heavy" launchers, and the duration that the treaty would remain in force.

Toward mid-April Kissinger began meeting secretly with Brezhnev to discuss SALT and arrangements for Nixon's impending visit scheduled for May. Kissinger returned from Moscow with a Soviet proposal on the SLBM and ABM issues in 
which Brezhnev indicated a willingness to include SLBMs at specified levels. The pace of compromise increased steadily as the summit date approached. By the time the President's negotiating team arrived in Moscow the only $A B M$ item left to agree to was the distance between the permitted ABM sites--a concern over radar overlap. A freeze on new ICBM launchers had already been agreed upon in Helsinki, and the levels of submarines and launchers resolved by Kissinger and Brezhnev.

All of the unfinished negotiating points were worked out in Moscow prior to the final signing of the treaties. One of the few remaining issues involved modernization and replacement, made somewhat difficult due to the problems of verification. Agreement was reached, however, on both issues; modernization and replacement being limited only by the provisions of the treaties themselves, and treaty compliance to be carried out by national means.

While the above summary of SALT I does not capture the complexity of the negotiations (i.e., technical details of the weaponry, or negotiating tactics) it does, however, highlight the key issues involved. Attempting to provide explanatory meaning to these issues is yet another matter. What were the motives behind those positions and proposals taken by both sides?

Why, for instance, was SALT able to begin in 1969 but not in 1968? Why were the negotiations policy goals of the United States and the Soviet Union? Why were the 
negotiations able to overcome serious obstacles? Why were the treaties signed in 1972? Why was the Soviet Union so adamant about including U.S. Forward-Based Systems? Why did the U.S. abandon its position for a comprehensive treaty? Many of these questions can surely be answered with reasonable reliability as products of certain political factors at work within the two countries. Others, however, can only be answered, or given more meaning, from the subsystem perspective.

\section{THE POLITICAL LEADER CHARACTERISTICS VARIABLE}

The Nixon Administration: Personal Attitudes

The unique personal qualities which Richard Nixon brought to the White House, together with the extraordinary circumstances in which he left, has presented itself as an intriguing case study to many observers; political scientists, historians, and psychoanalysts alike.

What emerges from the literature is a general consensus of Nixon; that he was pragmatic, conservative, insecure, paranoid, secretive, and self-aggrandizing. Barber classifies Nixon as an "active-negative" president.3 According to this analysis, Nixon's aggressiveness, his compulsive striving for power and status, and his inflexibility were contrasted by a destructive tendency, a weak ego, insecurity, and low self-esteem. The coexistence 
of these qualities eventually led to his downfall. He was his own worst enemy.

Mazlish, in his psychohistorical analysis of Nixon, emphasizes three overriding personality traits: his "almost unique absorption of self" in his role as president; his "ambivalence"; and, his "denial" in accepting his own aggressive nature. ${ }^{6}$ Nixon saw himself as a man of "greatness," but was paranoid in his fear of criticism, passivity, and dependence on others. ${ }^{7}$

According to Kissinger, who was closest to Nixon during his presidency, Nixon "feared rebuffs," was paranoid, and distrusted almost everyone, including members of his own cabinet. ${ }^{\circ}$ Aside from a few observers who view Nixon's policies as reflecting his true liberal character, his prepresidential "hawkish" views as nothing more than voteseeking rhetoric, 9 the more general feeling is one of a conservative Nixon whose anti-communist ideology and campaign rhetoric were dominated by his pragmatism in foreign policy once he took office.

\footnotetext{
Nixon came to office a strong backer of "superiority." As a candidate he had charged the Johnson administration with permitting a "security gap." He had called "parity" a "peculiar, unprecedented doctrine," and he said that "it appears that the closer we approach strategic parity, the further we move from a stable peace." He hoped, he had said, to be able to negotiate with the Russians, "from a superior standpoint."10
} 


\section{Participation}

After taking office in January 1969, Nixon indicated that his administration would base its soviet policy not on confrontation but "negotiation," not on military superiority but military "sufficiency."11 This policy goal not only reflected his pragmatism (which was influenced by Kissinger's "Realpolitik") but also demonstrated an intention that he, as President, would play the principal role in foreign policy decisionmaking.

Nixon's high level of participation in foreign policy decisionmaking was based partly on his personal desire for status and his distrust of others. But it was also based on a genuine interest and experience in foreign affairs. As Vice President under Eisenhower, Nixon traveled extensively, meeting with a number of foreign leaders. He also displayed a great intuitive ability for international politics. Kissinger "was struck by his perceptiveness and knowledge" on foreign policy. ${ }^{12}$

\section{Scope of Authority}

Nixon lacked a wide scope of authority and bipartisan support for his policy goals. In fact, Nixon's election victory over Humphrey was by a narrow margin in popular vote; 42.7 percent for Humphrey, and $\mathbf{4 3 . 4}$ percent for Nixon.13 If the ability to carry out policy goals is judged by his party's voting strength in Congress, then Nixon 
clearly needed bipartisan support. In both the House and the senate the Republican Party remained the minority party throughout Nixon's entire presidency. ${ }^{14}$

\section{Election Year Politics}

Nixon's october 1971 announcement of his intention to visit Moscow by May 1972 not only created a deadline for SALT (partIy due to the expectations usually reserved for summit meetings), but also prepared the way for the 1972 presidential elections. Success in SALT would be a big plus for Nixon come November.

Nixon would be just as anxious to show positive results to Congress, lest it begin to withdraw its support for new weapons programs. Nixon was concerned about losing his bargaining-chip leverage with the soviets, due to opposition with Congress. The senate had given its support for the Safeguard ABM program by a margin of only one vote.13 This was a clear statement to the president that Congress did not share his regard for bargaining-chip diplomacy as the best way to achieve arms control, or detente.

Nixon's announcement of the Moscow summit was conveniently timed in order to gain a much needed boost in his pre-election popularity ratings. Although his popularity among the American public was on average higher than that of most of his predecessors, 1971 became the low 
point of his term. Following the 1972 summit, however, his approval rating jumped to about 60 percent (see Figure 3). While Nixon had to deal with the constraint of a Democratic majority in Congress throughout his entire term, his re-election was also challenged by the fact that by January 1972 the Republican Party in Congress was outnumbered by Democrats by the widest margin in several years.16 Since Nixon's re-election rested on attracting a large segment of cross-party voters there was a heightened concern to demonstrate success as the "peace candidate." Next to seeking a resolution to the vietnam conflict, the achievement of a SALT treaty offered a most convenient strategy to secure that image.

\section{Nixon and SALT I}

Many of Nixon's characteristics are evidenced in U.S. arms control behavior during the SALT negotiations. Technological advances in nuclear weapons systems (ABMs, MIRVs, new strategic bombers) threatened to disrupt the relative stability in the military balance of the superpowers in the late 1960s. As the soviets continued to build their strategic forces to a level of parity with the United States, Nixon saw arms control as the best way to ensure a stable relationship. Arms control, however, was not seen as an end in itself. Nixon's style of diplomacy, "linkage," was to be applied to soviet behavior, not only 


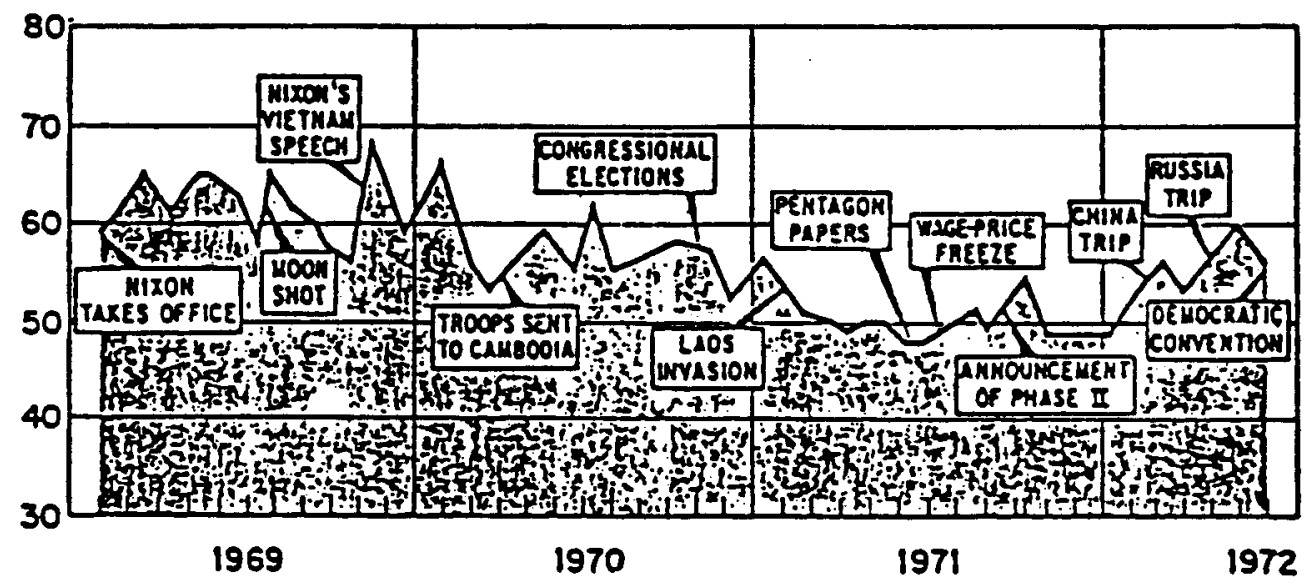

Figure 3. Graph of president nixon's popularity. The Gallup Opinion Index (No. 85, July 1972) p.2. 
in other regions of the world, but to strategic goals, with arms control concessions as incentives.

Another aspect of his negotiating style, similar to linkage, was his advocacy of "bargaining-chip" diplomacy; promoting research, development, and deployment of new weapons systems in order to gain concessions from the soviet Union.

Explicit in Nixon's style is the fact that he did not abandon his advocacy of superiority over the Soviet Union. Although it was couched in more conciliatory terminology, Nixon's own interpretation of parity and sufficiency meant that U.S. forces must not be inferior, and that there be no Soviet advantages with which to politically exploit the United States.17 Basically, these ideas amounted to a realistic acceptance of parity as long as the United states retained the military and political edge in deterrence. This edge, as Nixon saw it, was being given away willingly in President Johnson's SALT policy.

It was because of clear evidence of a growing soviet capability in 1969 that, he says, he decided in March 1969 to develop Safeguard, an ABM system better equipped to defend U.S. ICBMs.18 The opening of SALT was then delayed until November in order to buy more time to elicit Congressional support for a new weapons program at a time when the defense budget was facing increasing cuts. While the safeguard program was primarily to be used 
as a bargaining chip in SALT, it was also essential to the U.S. position favoring a comprehensive offensive/defensive treaty. By strengthening the U.S. position on ABM, which the Soviets wanted to see stopped, Nixon planned to Iink defense concessions to 1 imitations and/or reductions in Soviet offensive systems.

It was not only Nixon's pragmatism and style, however, that guided U.S. behavior in SALT. His paranoia and drive for personal power led him to rely increasingly on a few key people in policymaking--chiefly Kissinger. Nixon loathed the idea of allowing the bureaucracy its role in the decisionmaking process. He distrusted them, especially the State Department and the Foreign Service. According to Kissinger, "Nixon considered (Secretary of State) Rogers' unfamiliarity with the subject (foreign policy) an asset because it guaranteed that policy direction would remain in the White House."19

As negotiations continued, Nixon came to rely on Kissinger to such an extent that he began dealing with key foreign leaders through channels that directly linked the white House Situation Room to the field without going through the state Department--the so-called backchannels . . . Nixon increasingly moved sensitive negotiations into the White House where he could supervise them directly, get the credit personally, and avoid the bureaucratic disputes or inertia that he found so distasteful.20

While Nixon has been criticized for attempting to expand the power of the President, for ignoring the 
bureaucracy and Congress, and for sidestepping the U.S. SALT delegation, at times leaving them totally in the dark as to U.S. negotiating positions, ${ }^{21}$ it is probable that the backchannel negotiations prevented a much longer, drawn out SALT or even an eventual impasse had negotiations continued in their original manner. The Soviets were not budging at all from their "ABM only" proposal, and a growth in soviet offensive systems was reported to be steadily rising. It could also be argued that the soviets preferred the use of a more direct and unpublicized negotiating approach. Thus, the backchannel would have offered a more conducive atmosphere for serious negotiations.

\section{Analyzing Soviet Politics}

A tendency in many analyses of the decisionmaking process and leadership characteristics in soviet politics has been to employ analytic variations of comparative bureaucratic approaches and "interest group" approaches; 22 and "power consolidation" approaches.23 often times, studies that focus on comparative bureaucratic and interest group approaches in Soviet politics have relied too much on comparisons with the American political system. Whereas all bureaucratic institutions may be said to exhibit some similar qualities (i.e., employee identification with his or her organization, and inter-departmental "bargaining" and "coalition building"), 24 the degree of direct participation 
in actual policymaking is not so easily analogized. However, because of the unique "centralist" features of Soviet politics (a traditionally "rubber stamp" role of the legislative bodies and a somewhat more collective but independent authority vested in the executive), 25 greater attention to the role of the principal bureaucratic institutions and their influences within the Politburo seems in order.

The "power consolidation" approaches, on the other hand, focus on strengthening political position through coalition building and interest group support, patron-client relationships, and purges of organization membership.

\section{The Brezhnev Regime}

The general attitude toward Leonid Brezhnev's leadership characteristics is based on some combination of the above approaches plus his personal characteristics: an overall conservative approach, in personal outlook, and toward political reform; an ability to manage competitive interests within the system, and; whenever possible, the willingness and ability to augment his position of authority. Brezhnev was a devout communist, but a realist in the sense that he advocated co-existence (rather than unilateral antagonism) with the United states.

Within the various dichotomies ascribed to interest groups or factions in Soviet politics, Brezhnev has been 
classified: a "dove," as opposed to a "hawk";26 a "realist," as opposed to a "traditionalist"; ${ }^{2}$ "reformist," as opposed to "orthodox";28 a "diplomatist," as opposed to "conservative." 29 and, "pragmatist," as opposed to "conservative." 30

On a more personal level, Brezhnev was egotistical. had a thirst for power, was unfavorable toward change, and not a man of great intellect. According to Shevchenko, who knew Brezhnev on a personal basis,

Brezhnev's vanity was gargantuan and he was happy to nurture his own "cult of personality." His immodest behavior and the marks of undeserved distinctions and honors which he awarded himself were disgusting to many; in his love for praise, medals and honorary posts he surpassed even Khrushchev. ${ }^{31}$

Brezhnev's conservatism was partly a reflection of his own background and the aging generation of the stalin era, members of which included Brezhnev and most of his Politburo cadres. The average age of full (voting) members of the Politburo rose from 58 to 68 from 1966 to July 1978, while the average age of candidate (non-voting) members rose from 53 to 65 during the same period.32 As shevchenko notes:

The old men . . had settled into an intensely conservative pattern. . .. in which they feared and would not tolerate any changes or new ideas; they liked the reassurance of familiar slogans repeated and repeated... ${ }^{33}$

Brezhnev had learned early on how to survive in the system as a Party apparatchik during the stalin purges of the 1930s. He moved up through the ranks of the Party 
hierarchy not as an intellect or an innovator, but by cultivating his political connections and winning the favor of Khrushchev. Thus, as Shevchenko explains, "Brezhnev was simply one among many ordinary faces that from time to time appeared and disappeared on the political horizon."34 Even as a Party leader,". . . it was clear to all who knew him that he was a man of limited intellect and ability."os

\section{Brezhnev and SALT I}

Perhaps, the three principle characteristics of the Brezhnev regime as they relate to SALT were the constraints prompted by intra-factional debate within the top leadership, ${ }^{36}$ the economic priorities of the leadership, and the building of Brezhnev's power base during that period. The soviet decision to enter into negotiations with the United states appears to have been made during a period when Brezhnev had yet to achieve preeminence in the Politburo, thus allowing considerable internal debate over policy choices. As Wolfe suggests the months between President Johnson's invitation to the soviets to begin negotiations in January 1967 and the first Soviet announcement of their willingness to negotiate in June 1968 were marked by an internal debate within the leadership on the issue of arms control.37 Since Brezhnev's position was not firmly established until 1971, the early phases of SALT were influenced by this debate. This is evidenced by a "hold and 
explore" behavior, discussing issues in generalities, and a tentativeness as to whether SALT should continue past the first round. ${ }^{38}$

Although Brezhnev was Party Secretary General, he did not yet dominate foreign policy. This area, which included SALT, was directed by Premier Alexei Rosygin until $1971 .{ }^{39}$ The fact that Kosygin was also "pro-arms control," however, and the fact that a pro-arms control policy eventually won out, cannot entirely explain Brezhnev's eventual domination over foreign policy.

Clearly the difference between the two leaders lay in their motives for arms control, with Brezhnev's ascendancy being a tribute to his ability to manage competing interests while strengthening his own position. Rosygin linked arms control to the reallocation of resources to light industry and consumer satisfaction. Brezhnev was committed to a detente as part of a strategy to slow down U.S. military programs, but also to maintain a high rate of development in heavy industry.

To the military this direction was somewhat of a departure from building a "favorable" relationship of forces, but it was acceptable in comparison to that of Rosygin. With the tenacious baking of the military Brezhnev succeeded in cutting back increased military spending in 1970.40 Brezhnev gained further domination over the military when the 24 th Party Congress in 1971 failed to 
elect Dmitri Ustinov, head of the armaments industry, to full membership in the Politburo.

By mid-1971 Brezhnev had consolidated his own position but was bound by the constraints of having to appeal to several interests.4 His credibility at home, particularly with the pro-defense groups, made a SALT agreement all the more a priority. Assuming that Brezhnev correctly perceived a SALT treaty as essential to Nixon's re-election, 42 the motivation for the signing of SALT in 1972, prior to the November elections, is clearer still.

\section{THE SUBSYSTEM VARIABLES}

It is generally accepted that the period of SALT I was associated with a detente; 43 overall, a positive period in East/West relations. The subsystem data for 1969 through 1972 support this association (see Table I in the Appendix). The significance of this association, however, depends upon whether detente acted more as a determinant of SALT. Viewed from the domestic perspective, the pursuit of a SALT agreement was the keystone of detente; the agreements themselves affirmed its reality and promoted its viability. The subsystem perspective, however, presents a different view. Detente was responsible for the success of SALT. No matter how much policies toward an arms agreement were encouraged domestically, sALT codified detente but did not initiate it. 
Although the SALT process had been set in motion during the Johnson administration, with preparations underway for a US/Soviet summit meeting in the fall of 1968 , the political conditions were not yet conducive to bringing the two sides to the negotiating table for formal talks. The summit meeting was canceled by Johnson supposedly in response to Soviet military action in Czechoslovakia.

Surely this event did nothing to promote East/West relations, but neither did it reflect overall changes in the subsystem relationships.

By 1968 there had been a general, albeit slow movement toward an East/West detente, though much of the cold war tensions remained. A number of changes in the international political environment can be cited which encouraged this detente: a growing rift in sino/Soviet relations; a European desire to relax East/West tensions, particularly on the issue of German reunification; the questionable future of NATO, caused by tensions both within Western Europe and between the European allies and the United States over such issues as the European Economic Community (EEC) and European integration, U.S. involvement in Vietnam, and the unilateral decision by the United States to adopt a "flexible response" strategy for the defense of the alliance.

The perceived missile gap of the early 1960 s had been replaced by a perceived stability in the military balance, although technological advances in nuclear weaponry (ABM, 
MIRVs, new strategic bombers, and ICBMs) threatened to disrupt that balance in the near future. With the continued buildup of Soviet strategic forces, the United States was being forced to accept the concept of parity in its relationship with the Soviet Union. Detente really did not begin to build momentum until after 1967. In December of that year NATO adopted a new strategic policy of "flexible response" and approved the Harmel Report on the Future Tasks of the Alliance. West European security concerns were heightened as a result of the new strategy which was perceived by many as America's growing unwillingness to defend Europe in the event of a Soviet move into Europe. "Flexible response" was also seen as making conventional war in Europe more likely. As Rissinger described the strategy,

The strategy had been accepted by our European allies with extreme uneasiness and only after a debate extending five years. They saw it correctly-as the symptom of growing reluctance by the United states to use its nuclear forces.44

The Harmel Report stated that "military security and a policy of detente are not contradictory but complimentary," and that "allies are not obliged to subordinate their policies to collective decision."45 The significance of the Report was that it explicitly called for an alliance policy based on "parallel courses" rather than, what Beers terms, a "common tack."46 Western Europe would no longer be obliged to simply mirror U.S. policy, but would, with U.S. endorsement, pursue a more independent course toward common 
goals. Although the Report may have alleviated somewhat the tensions between the United States and Western Europe, by formally opening the way for a more active West European process of normalization with the East new tensions arose in the alliance relationship over how best to achieve detente, and the pace at which detente would be pursued.

DeGaulle had already made it clear that France intended to pursue its own course independent from U.S. policy, and had conveyed France's desire to seek better relations with the Soviet Union.47 West Germany began a more active attempt of its own to further detente. In 1968, while Germany was still "being officially branded as a hostile power seeking revenge and restoration of territorial losses. . "48 by the end of 1969 German Chancellor Brandt's "Ostpolitik" was in full swing. And the soviets were responding with equal enthusiasm. The success of a European detente, however, particularly for West Germany, rested on greater US/Soviet cooperation. West European pressure on the United states to actively engage in arms control was thus intensified. The United states, taking a slower, more cautious approach to detente, nonetheless took great note of its allies' concerns, if only for the threatening implications that a separate west European/Soviet detente had for U.S. security. As the Soviet Union pursued a "selective detente" policy49--to divide the alliance by courting Western Europe, 
the United states feared the possibilities of rising German nationalism, 50 West European neutralism,51 and an eventual "finlandization" of Western Europe.52 Within this political atmosphere the United States was faced with a challenging dilemma :

how to maintain security while seeking to improve-for the first time--systematically--relations with the East; how to reconcile our solidarity (alliance unity) with a policy of detente. ${ }^{33}$

Kissinger's words not only reflect the policy dilemma facing the United states at that time, but the fact that it was viewed as a dilemma demonstrates both the priority of alliance unity in U.S. security policy and the indirect role of Western Europe on U.S. policymaking. Whereas in 1968 the United states was willing to hold back on arms control, as it was apparently in the first months of the Nixon administration, the political environment by late 1969 favored SALT negotiations as the logical policy alternative. By the time of the opening round of talks in November 1969 the subsystem environment was characterized by a slightly positive, but cautious adversarial relationship, a generally positive alliance relationship, but with strong underlying negative elements, and a relatively high degree of positive behavior in the alliance/adversary relationship (see Appendix Table II) .

The second and third rounds of SALT in 1970, by contrast, took place amidst a slightly negative adversarial 
relationship, and a highly positive alliance/adversary relationship (see Appendix Table III). This change in conditions featured U.S. expansion of the Vietnam War into Cambodia, signs of crisis in the Middle East, Soviet criticism of movement toward a US/Chinese rapprochement, growing West European independence from U.S. policy, and continued Soviet effort to lure Western Europe away from the United states.

Clearly the latter feature was most evident during SALT, demonstrated by Soviet positions on such issues as ABMs, MR/IRBMS, FBS, and British and French nuclear forces. While the Europeans generally welcomed SALT as being "consonant with efforts to secure a more general relaxation of East/West tensions," they were concerned that a SALT treaty "might sacrifice some part of its (American) capability to protect allies," including their own capability to protect themselves.54

At the outset of SALT the soviets raised the issue of American Forward-Based Systems (an area of U.S. advantage), demanding that they be included in any agreement limiting nuclear weapons systems. At the same time they insisted that their medium-range missiles aimed at Western Europe not be included. This they justified by their own definition of strategic weapons. Puzzled by this Soviet behavior Smith asks, what did the Soviets expect to gain by raising this issue? Attempting an answer he concludes that, 
because the allies were so adamant about any reduction in the U.S. commitment to Western Europe.jo

Another West European concern, one closely linked to the independent nuclear forces of Britain and France, was the ABM issue. Not only were the development and deployment of U.S. defensive systems perceived by Europeans as a move to "insulate" the United States from its allies, but a Soviet defensive capability was seen as a threat to the utility of British and French forces. ${ }^{37}$ Obviously even a limited number of soviet ABMs would have a significant effect on the comparatively small forces of Britain and France combined. The soviet proposal calling for joint retaliation against any country launching a provocative attack further aggravated the British and French situations by indirectly constraining the utility of their forces. While the proposal was also directed at the Chinese, the Soviets had likely considered the benefits of both.

The FBS debate continued into the third round of talks in November 1970 as both sides held to earlier positions. In December a Soviet proposal was conveyed via the delegation heads that upon completion of an agreement both sides would agree to adhere to a no first-strike policy. This proposal was clearly designed with the aim of isolating Western Europe. For the United States to officially adopt such a policy would have antagonized the allies even more than "flexible response" had. The U.S. response to the 
proposal was predictable. ". . . it would be inconsistent with defensive commitments to our allies. . ."58

The friction in the alliance relationship during 1970 , however, was not entirely negative. It would be more aptly described as confused--neutral, but volatile; equally likely to improve or worsen. Even as the United states was urging its allies to increase their share of the cost of defense and cautioning them against being too quick to pursue detente, it was also nurturing their trust through the reassurances of close consultation and the affirmation of its alliance commitments in SALT.

Early in 1969 Nixon had promised the allies full consultation. The U.S. SALT delegation stopped first in Brussels en route to Helsinki to confer with the allies. Thereafter, briefings on the negotiations and U.S. positions were carried out on a regular basis. Nixon also kept his promise for an extensive visit to Europe early in his first term. Before his trips to China and Moscow Nixon consulted at length with allied leaders at the White House. Although some NATO members found that consultations with the Nixon administration were "little more than a willingness to inform others what it had already decided to do," consultations were somewhat successful in calming allied "nervousness." 59

The West Europeans were in an uneasy position. As noted earlier, although they welcomed SALT, they remained 
apprehensive about a US/Soviet agreement which might lessen America's alliance commitment. Furthermore, any desire they may have had to take on a larger role in NATO policymaking and a more independent role in providing for their own defense, was contradicted by the desires for a detente and the undesirable costs of assuming a greater defensive role. They too fully understood the political implications of an East/West detente. As Kissinger later warned, "an atmosphere of detente removes the previous urgency for allied cohesion."60

The West European/Soviet detente, however, was sustained through 1970 with the alliance/adversary relationship overall a positive one (see Appendix Table III). Among the more positive events were the opening of bilateral negotiations between East and West Germany, the beginning of four-power negotiations on Berlin, positive movement toward the Conference on Security and cooperation in Europe (CSCE) and Mutual and Balanced Force Reduction (MBFR), and the signing of non-aggression treaties between the Soviet Union and West Germany. In October France and the Soviet Union signed an accord to further develop and expand relations, and to have periodic consultations.

Despite the passivity in SALT during 1970, much progress was made in 1971, culminating in the SALT I treaties of 26 May 1972. This period is associated with an overall positive subsystem environment (see Appendix Tables 
IV and $V)$. The United States and the Soviet Union engaged in a higher level of cooperation despite counter-productive events (i.e., U.S. moves toward mending relations with the PRC, and the U.S. mining of North Vietnamese ports.

The political environment in which SALT was achieved had thus been established. Ostpolitik relied on Us/Soviet cooperation for momentum. The United States relied on cooperation with the Soviet Union in order to maintain some control over Ostpolitik and alliance unity. The soviet Union relied on cooperation both with the United States and Western Europe in order to relax NATO's raison d'être and constrain U.S. military programs. SALT I was thus greatly facilitated because the interaction of each actor's security concerns, and their attendant policies, created conditions favorable for arms control.

\section{CONCLUSION}

Viewed solely from the domestic perspective, SALT I was the keystone of detente. Implicit in this view is the belief that without the political forces within the United States and the Soviet Union acting in favor of SALT detente would have quickly become a dead issue. Certainly the coincidence of SALT and the blossoming of the detente era is strong evidence in favor of this position. In addition, since the policies of the Nixon administration and that of Brezhnev both embraced philosophies of international order 
based on adaptation, peaceful coexistence, and conflict management, in which arms control played a key role, it is not difficult to arrive at conclusions which define the success of SALT I as the result of bilateral relations.

This view, however, would be only partially correct. If the foreign policies of the United States and the Soviet Union by 1969 were compelled toward cooperation and conciliation, they must be seen as adapting and reacting to sub-systemic influences more than the results of bilateral or domestic factors.

The Ostpolitik of Western Europe somewhat frustrated the implementation of Kissinger's balance of power philosophy in which Western Europe was subjugated to U.S. policy. Western Europe was advancing its own policy of detente separate from U.S. policy. Western Europe saw SALT as a way to allay its own fears of entrapment. The soviet Union reacted by encouraging closer ties with Western Europe. SALT was used as a carrot to court Western Europe and divide the alliance. The United states reacted by using SALT as a means of controlling alliance solidarity and west European/Soviet ties.

According to the data in Figure 2, US/Soviet relations peaked in 1971, but were slipping as the SALT I treaties were signed. Alliance relations appear to parallel US/Soviet relations while West European/Soviet relations run contrary. 
This supports the thesis that SALT I was preceded by an environmental movement toward East/West detente already underway by the late 1960s. SALT I negotiations were motivated by security perceptions, particularly those of Western Europe, that sought an end to East/West confrontation. By 1970 alliance relations were low as the United States and Western Europe followed distinct soviet policies. Western Europe pursued Ostpolitik in reaction to its concerns of entrapment. Accordingly, the soviet Union welcomed Ostpolitik. The United States, responding to allied concerns and its own concern over warming west European/Soviet relations, initiated SALT negotiations in 1969. Alliance relations and US/Soviet relations rose accordingly. Detente was a result of these changed relationships. SALT I was the product of detente. 
CHAPTER II NOTES

1 Two primary sources for this section include, Gerard Smith, Doubletalk: The Story of the First Strategic Arms Limitations Talks (Garden City, N.Y.: Doubleday, 1980); and, John Newhouse, Cold Dawn: The Story of SALT (N.Y.: Holt, Rhinehart and winston, 1973).

2 These weapons systems included bombers, submarines, and carrier-based aircraft, based within striking distance of the Soviet Union.

${ }^{3}$ Smith, Doubletalk, p. 185.

4 Ibid., p. 186 .

S James David Barber, The Presidential Character

(Englewood Cliffs, N.J.: Prentice-Hall, 1972).

'Bruce Mazlish, In Search of Nixon: A Psychohistorical Inquiry (N.Y.: Basic Books, Inc., 1972), p. 148 .

7 Ibid., p. 115.

'See Henry Kissinger, The White House Years (Boston: Little, Brown, and Co., 1979).

'See, for example, Gary Allen, Richard Nixon: The Man Behind the Mask (Belmont, MA: Western Islands, 1971).

${ }^{\circ}$ Chalmers M. Roberts, "The Road to Moscow," in Mason Willrich and John B. Rhinelander, eds., SALT: The Moscow Agreements and Beyond (N.Y.: Free Press, 1974), p. 23.

11zbigniew Brzezinski, "The State of Nixon's World," Foreign Policy (No. 3, Summer 1971), pp. 17-18.

12 Rissinger, The White House Years, p. 12.

13 Statistical Abstract of the United States 1982-1983, "Vote Cast for President," (Washington D.C.: U.S. Bureau of the Census, 1982), p. 472 .

14 Ibid., "Composition of Congress," p. 483.

15Richard M. Nixon, The Real War (N.Y.: Warner Books, Inc., 1980), p. 167 .

p. 2 .

${ }^{16}$ The Gallup Opinion Index (No. 79, January 1972), 
${ }^{17 N i x o n, ~ T h e ~ R e a l ~ W a r, ~ p . ~} 154$.

18 Ibid., p. 167 .

${ }^{19} \mathrm{Kissinger}$, The White House Years, p. 26: words in parentheses are mine.

20 Ibid., p. 29.

21See, for example, Smith, Doubletalk, pp. 210-211;

and, pp. 233-234.

22 For a brief but insightful discussion of these main approaches see, for example, Jerry Hough and Merle Fainsod, How the Soviet Union is Governed (Cambridge: Harvard University Press, 1980), pp. 518-529.

${ }^{23}$ For a distinction between these approaches see, George w. Breslauer, Khrushchev and Brezhnev as Leaders: Building Authority in Soviet Politics (London: George Alien and Unwin, Ltd., 1982), p. 3 .

24 For a discussion of these qualities see, for example, Lincoln P. Bloomfield, The Foreign Policy Process (Englewood Cliffs, N.J.: Prentice-Hall, 1982), pp. 159-163.

${ }^{23}$ It should be pointed out that whereas the legislative and executive branches refer to the governmental structure, the Communist party, having its own parallel structure, dominates governmental decisionmaking. The Politburo, being a Party organization, includes as its members, the secretaries and Ministers of government. As an additional note, a more "collective" role for the Politburo has generally been applied to soviet political analysis in the post-stalin era.

${ }^{26}$ See for example, Roman Rolkowicz, The Red Hawks on the Rationality of Nuclear War (Santa Monica: Rand Corp., 1966).

27 See John Lenczowski, Soviet Perceptions of U.S. Foreign Policy (London: Cornell University Press, 1982).

28 See Marshall D. Schulman, "SALT and the Soviet Union," in Mason Willrich and John B. Rhinelander, eds., SALT: The Moscow Agreements and Beyond (N.Y.: Free Press, 1974)

29 See, Dan L. Strode and Rebecca V. Strode, and Defense in Soviet National Security Policy,"

"Diplomacy International security (Vol. 8, No. 2, Fall 1983). 
${ }^{30}$ Roman Rolkowicz, et al., The Soviet Union and Arms Control: A Superpower Dilemma (Baltimore: Johns Hopkins University Press, 1970), pp. 38-49.

${ }^{11}$ Arkady N. Shevchenko, Breaking with Moscow (N.Y.: Ballantine Books, 1985), pp. 25-26. p. 272 .

${ }^{32}$ Hugh and Fainsod, How the Soviet Union is Governed,

33 Shevchenko, Breaking with Moscow, p. 25.

34 Ibid. , pp. 168-169.

35 Ibid., p. 26.

${ }^{36}$ This debate, for the most part, was between members of the military and diplomatic corps, between advocates of heavy industry and advocates of consumer satisfaction.

37Thomas H. Holfe, "Soviet Approaches to SALT," Problems of Communism (Vol. XIX, September-october 1970), pp. $6-7$.

${ }^{38}$ Ibid., p. 8 .

${ }^{39}$ See Rissinger, The White House Years, p. 527; and Schulman, "SALT and the Soviet Union," pp. 114-116.

40 Sidney I. Ploss, "Politics in the Rremlin," Problems of Communism (Vol. XIX, May-June 1970), p. 8. The defense budget for 1970 was to increase by only 1.1 percent, as compared with a 6 percent increase in 1969, and a 15 percent increase in 1968 .

41 Myron Rush, "Brezhnev and the Succession Issue," Problems of Communism (Vol. XX, July-August 1971), pp. 1314.

42 Newhouse, Cold Dawn, pp. 219-220.

43 Jack C. Plano and Roy Olston, eds., The

International Relations Dictionary, (Santa Barbara, CA: ABCCLIO, Third Edition, 1982), pp. 233-234.

44 Kissinger, The White House Years, p. 391.

45 "The Harmel Report," NATO Handbook (NATO Informational Services, Paris, 1979), pp. 75-77.

${ }^{46}$ Francis A. Beers, Integration and Disintegration in NATO (Columbus: Ohio State University Press, 1969), p. 43. 
${ }^{47}$ New York Times (January 1st, 8:1, 1970). In a New Year telecast President DeGaulle says the basic tenet of French foreign policy will be detente with the East.

48 Andrzej Rorbonski, "Issues for Global Actors: The USSR," in Gavin Boyd and Charles Pentland, eds., Issues in Global Politics (N.Y.: The Free Press, 1981), p. 112 .

${ }^{49}$ Kissinger, The White House Years, p. 410.

soIbid., p. 410. This was more a personal concern of Kissinger.

-1 Ibid.. p. 403. For a more technical definition of "neutralism" see, Plano and Olton, eds., The International Relations Dictionary, pp. 36-37.

-2The term "finlandization" came about because Finland's foreign policy was subjugated to soviet power during World War II. for a brief history see, for example, Adam B. Ulam, Expansion and Coexistence: Soviet Foreign Policy 1917-73 (N.Y.: Holt, Rinehart and Winston, 1974), pp. 289-295.

In deterrence theory, the term is associated with the idea that strategic parity between the United states and the Soviet Union may lead to a situation in which the U.S. nuclear umbrella over Western Europe is no longer credible, allowing the soviet union to project a "shadow" of military power westward, thus politically dominating Western Europe. See, for instance, James E. Dougherty and Robert L. Pfaltzgraff, Jr., "Nuclear Deterrence and Flexible Response in Europe," Contending Theories of International Relations (N.Y.: Harper and Row, 1981), p. 384 .

skissinger, The White House Years, p. 390. Words in parentheses are mine.

"Ian Smart, "Perspectives from Europe," in Willrich and Rhinelander, eds., SALT: The Moscow Agreements and Beyond, p. 188. Words in parentheses are mine.

5 Smith, Doubletalk, pp. 92-93.

${ }^{56}$ Smart, "Perspectives from Europe," p. 192.

57 Ibid., pp. 190-191.

$58 \mathrm{Smith}$, Doubletalk, p. 190.

"9mart, "Perspectives from Europe," p. 190. 
${ }^{6}$ Henry Rissinger, The Troubled Partnership: A Reappraisal of the Atlantic Alliance (N.Y.: Anchor Books, 1975), p. 10 . 


\section{CHAPTER III}

\section{SALT II}

\section{THE ISSUES OF SALT II}

Less than six months after SALT I became official U.S. and Soviet negotiating teams arrived in Geneva to begin SALT II.1 For the most part, these negotiations took place within the framework of SALT I, the main objective being to replace the Interim Agreement (due to expire in five years) with a more comprehensive one that would remain in force for a substantially longer period. Issues that were either put off in SALT I (FBS, MR/IRBMS, MIRVs, soviet MLBMs) or not yet deemed strategically or technologically essential to the purpose of SALT I (Backfire Bomber, cruise missiles, or the MX--"Missile Experimental") were brought up in SALT II.

of immediate concern in SALT II was what many American strategic planners and politicians alike saw as the failure of SALT I; solving the problem of Soviet "heavies--their MLBMs. ${ }^{2}$ These missiles, they argued, threatened the retaliatory utility of the U.S. Minuteman ICBMs--the backbone of the land-based leg of the U.S. nuclear triad. Some limitation or reduction of these missiles quickly became a U.S. priority, particularly in light of the fact 
that the Soviet Union would be left free to MIRV them. Although U.S. MIRV technology far exceeded that of the Soviet Union during SALT I (which was one justification for the launcher inequality in the Interim Agreement), it was argued that once the soviets did begin MIRVing, U.S. missiles would be placed in an inferior position.

Because of this growing criticism of SALT I, Congress had mandated that future agreements be arrived at on the basis of numerical parity, or "equal aggregates."3a This meant taking into consideration both quantitative and qualitative aspects of nuclear weapons systems (i.e., launchers, warheads, missiles, throw-weight, range, accuracy).

By June 1973 some general guidelines were worked out between Nixon and Brezhnev in Washington D.C. Together they agreed to work toward permanent ceilings on offensive strategic forces (including qualitative factors), and toward a real mutual reduction of those forces. They also agreed upon 1974 as a deadline for concluding a SALT II treaty. BY the summer of 1974, however, negotiations were bogged down. But despite Nixon's resignation from office in August, efforts to continue the SALT process were not given up. In fact, what was generally accepted as a "get acquainted meeting" between President Ford and Brezhnev in Vladivostok, turned out to be a significant step forward for SALT. Principles agreed upon at vladivostok gave a new impetus to 
progress in SALT and set the stage for the next four years of negotiations.

A ceiling was established at 2400 for total offense nuclear launch vehicles, with a sub-ceiling of 1320 launchers for MIRVs. The soviets dropped their demand that an agreement include American FBS. In return, the United States agreed not to press for a reduction in soviet "heavies." The ceiling of 2400 would also include heavy bombers, a category in which the United States had superiority. A new deadine for concluding an agreement was set for the end of 1975 .

Two issues quickly became a major stumbling block for the remainder of SALT II--the Soviet Backfire Bomber, and the cruise missile." The problems were primarily ones of definition. The Backfire's unique characteristics gave it a medium bomber status, though it had intercontinental (strategic) capabilities. The cruise missile (still in the developmental stage in 1974) did not have the range or speed of ballistic missiles or heavy bombers. But it could strike the Soviet Union from forward bases in Europe. Thus, by Soviet definition, the cruise missile was a strategic weapon. In addition, 30-40 air-launched cruise missiles (ALCMs) could be delivered by one bomber, a feature on which grounds the Soviets insisted that such a bomber be counted in the MIRV launcher sub-ceiling.

While the delegations in Geneva marked time discussing 
less ambiguous issues, no headway was made during 1975 on the "gray area" status of the Backfire and cruise missiles." In January 1976, Rissinger flew to Moscow anxious to break the impasse and reach an agreement. The result of his meeting was an understanding that the United States would count heavy bombers armed with cruise missiles within the MIRV launcher ceiling of 1320 if the Soviets would accept Iimitations on the Backfire. This understanding, however, was never allowed to provide the breakthrough in negotiations that Rissinger had hoped for. His concession on the cruise missile was subsequently blocked by internal pressure in the United States. ${ }^{6}$ In February the United States offered a counterproposal that the vladivostok agreements be ratified with a temporary resolution of the Backfire and cruise issues. The Soviets rejected the proposal claiming they had made a deal with Kissinger. Finally, with another treaty deadine past, the negotiations moved through an ambiguous phase until March 1977. The Carter administration then focused on three options: "Basic Vladivostok"--more or less what Rissinger had arranged in January 1976; "Vladivostok Plus"--including some accommodation of the Backfire, and: "Vladivostok Minus"--excluding the Backfire and the cruise missile. The final decision became the "Comprehensive Proposal" which: reduced both total launcher and MIRV launcher ceilings; added a sub-ceiling of 550 for MIRVed ICBMs; reduced the 
number of Soviet heavy bombers to 150 (from 300); limited the flight testing of existing ICBMs; banned mobile and new ICBMs, and; excluded further limitations on the Backfire, if the Soviets would restrict its mission to tactical only. All cruise missiles would be limited to a range no greater than $2500 \mathrm{~km}$., but deployment of ground-launched cruise missiles (GLCMs) would be acceptable in west Germany. The Soviets rejected the proposal.

over the next two years the two sides did manage to converge on several issues. In April 1978 secretary of State Vance visited Moscow in an attempt to resolve the remaining problem areas. There was hope that a summit meeting, and possibly a treaty, could be arranged by summer. The United States agreed to a lowered ceiling of 2250 total nuclear launch vehicles (but higher than the Comprehensive Proposal) and the Soviets agreed to a 1200 MIRV launcher ceiling. They also dropped a demand that transfer of weapons systems and technology be banned. In its place a U.S. proposed "circumvention" clause was adopted.

In May 1978 the Soviets accepted a freeze on the maximum number of warheads per missile, the limit based on the present number of warheads on each missile. The soviets then proposed a ban on flight testing and deployment of all new ICBMs except one, which would be limited to a single warhead missile. This was unacceptable to the United States since it would have blocked the MX missile which had ten 
warheads. In July, however, the Soviets compromised and agreed to allow one new ICBM, MIRVed or not. The United states agreed, and at the same time abandoned a similar proposal of its own to ban new SLBMs. Such a ban would have blocked the Trident II program.

By early September 1978 a treaty seemed to be within reach. The United States approached Moscow with a "package" deal with all but a few issues remaining to be resolved. Over the next few months the talks focused on cruise missiles, the Backfire, and treaty verification. In late September the soviets offered to drop their $2500 \mathrm{~km}$. limit on ALCMs in exchange for a "straight line" range limit on GLCMs and sea-launched cruise missiles (SLCMs). ${ }^{7}$ Shortly thereafter, the soviets dropped the $2500 \mathrm{~km}$. limit on GLCMs and SLCMs in return for a U.S. agreement to a $600 \mathrm{~km}$. limit in the protocol of the treaty. The soviets did not, however, drop their right to upgrade the Backfire.

An October meeting in Moscow focused primarily on the issue of verification. In response to the soviet practice of encrypting some of its missile testing telemetry, the United states insisted on banning any encryption that would impede "national means" of verification. This would be accomplished by the inclusion of a clause (similar to one in SALT I) that prohibited the deliberate concealment of missile telemetry which might impede verification. By December the verification issue, plus a U.S. insistence that 
a treaty include a soviet statement of non-strategic intentions for the Backfire, stalled the talks again. By the end of 1978, as expectations mounted for a summit meeting, and a treaty, the talks were delayed for another six months. Following almost weekly negotiations, the remaining issues were worked out and SALT II was finally signed on 18 July 1979.

The treaty kept the 2400 ceiling on total launchers, but included a reduction to 2250 by 1 January 1981. The sub-ceiling for MIRVs stayed at 1320 , and included heavy bombers equipped for cruise missiles with a range over 600 $\mathrm{km}$. A limit was set at 28 ALCMs per bomber. Both GLCMs and SLCMs were limited to $600 \mathrm{~km}$. in the protocol to the treaty, which would remain in force until 31 December 1981, unless replaced by an earlier agreement. MIRV launcher subceilings were set at 1200 for ICBMs, SLBMs, and Air to Surface Ballistic Missiles (ASBMs), and at 820 for ICBMS only. Each side was allowed to determine its own mix within those limitations. No new type of ICBM was allowed, except one new "light" ICBM. The number of MIRV warheads was capped at existing numbers.

Limitations were also agreed upon for modernization, relocation, conversion, and reloading of ICBM launchers. The circumvention clause was retained in Article 12 of the treaty, as was the U.S. insistence to include a "no deliberate concealment measures" clause in Article 14. 
Article 19 set the expiration date for the treaty at 31 December 1985 .

The treaty also included a soviet statement that the intercontinental capabilities of the Backfire would not be utilized, and that its production rate would not exceed thirty planes per year. President Carter included a statement that the United States considered these Soviet commitments on the Backfire "to be essential to the obligations assumed under the Treaty." Finally a Joint Statement on Principles and Basic Guidelines for Subsequent Negotiations was included with a reference to further resolution of the issues designated in the protocol. Senate debate over SALT II ratification immediately began following the treaty signing and continued for the remainder of 1979.8 By Christmas recess, SALT II had not yet been brought to a vote, and subsequently was never ratified.

THE POLITICAL LEADER CHARACTERISTICS VARIABLE

Nixon (1973-1974)

By the time of the opening round of SALT II Nixon had been re-elected by a landslide majority. 9 Having interpreted the overwhelming victory as a clear mandate for his policies, Nixon continued to govern in much the same manner and style. By the end of January 1973, however, Nixon's popularity among the American public declined steadily. Following his April speech regarding the 
Watergate break-in, that rating dropped to its lowest point since taking office.10

Regarding SALT II, the effect of Watergate on U.S. arms control behavior must be seen as minimal, at least until the summer of 1974. Nixon's approach was business as usual. It may be speculated, however, that the 1973 summit was purposefully predisposed toward conciliation and highly celebrated in order to distract attention from watergate, thus highlighting the success of the administration's foreign policy. Whether or not this was the case in 1973 , it seems more probable that the 1974 summit in Moscow had such motivations. The soviets by then, however, could not have realistically agreed to further arms control measures in light of the overwhelming uncertainty facing U.S. leadership. Despite the high expectations and publicity surrounding the summit, very little was accomplished.

\section{The Ford Administration}

"Gerald Ford, the first appointed American President, a pleasant, dull, open-faced man . . " assumed the office of President on 8 August 1974.11 Contrary to what has been considered an interregnum, 12 the Ford administration, at least in regard to foreign policy, represented a continuation of the policies of the Nixon administration. The SALT II negotiations were absent of any radical departure from the Nixon years. Ford retained Rissinger as 
Secretary of state. Ford's instructions were to move ahead with SALT where Nixon had left off.13 The Vladivostok meeting, coming just a few months after Ford assumed office, is demonstrative of the Ford administration's desire to maintain consistency and continuity in arms control policy. It is also reflective of the desire to renew a detente that was becoming increasingly a target of domestic criticism.

There were, of course, several real constraints on the Ford Presidency. Beside the fact that he was not elected, there was the debate over the possible consequences of the U.S. incursion into Cambodia, and later the U.S. withdrawal from vietnam. These issues, together with the Watergate affair, severely undermined the office of the President, at home and abroad.

Ford also had to deal with stronger Democratic majorities in both houses of congress. The composition of the 94 th Congress following the 1974 elections included more than a twenty percent increase in House Democrats as well as establishing a commanding sixty percent Democratic majority in the Senate.14

Ford thus found it difficult to continue the policies of his predecessor. The 1975 deadline for a SALT II treaty, set at Vladivostok, came and went with no sign of a breakthrough in negotiations. Kissinger, whose association with the Nixon era, and whose world views had become associated with America's failure in vietnam, also came 
under attack. In Richard Barnet's words, "the man who made foreign policy famous no longer seemed to be able to make foreign policy."15 Unable to find a compromise solution to the negotiating obstacles posed by the Backfire and cruise missile, Kissinger visited Moscow in January 1976 to attempt a last ditch effort.

Once again the predisposition toward election year politics was an important motivating factor in the pursuit of a SALT agreement. As Ford himself alluded to,

A SALT accord had been eluding us for more than a year, and it was vital that we make a final attempt to bridge our differences over the Backfire and cruise. success with SALT . . would go a long way toward ensuring my election in $1976 .{ }^{16}$

By 1976, however, detente, SALT, and Rissinger were under attack from members of both major parties. By March detente was a term no longer in vogue, and even Ford discarded it from his campaign rhetoric. ${ }^{17}$ Criticism of detente, as a one-way street in favor of the Soviet Union, was substantiated by Soviet actions in Angola and the detection of new soviet missile deployments.

SALT negotiations continued. But as Talbott has observed, "Kissinger was on a shorter leash... as he negotiated with Gromyko."10 Kissinger's attempt at a treaty by agreeing to limitations on the cruise missile was viewed by many U.S. policymakers as an unacceptable concession to the Soviets. Mounting domestic pressures against detente disallowed an American compromise in SALT. The Soviets, on 
the other hand, seemed content to hold out for a favorable arms control deal in a U.S. election year. SALT II was thus resigned to an ambiguous state until March 1977.

\section{The Carter Administration}

According to some post-presidential analyses, Jimmy Carter has been described, in most general terms, as "a good man," but with "little sense of direction."19 while this description is simplistic, it does capture the ambiguity and vacillation associated not just with the man, but with the administration and its policies. The question that must be asked then, is to what degree were these characteristics a part of Carter's personality, his political style, his participation in decisionmaking, and the constraints on his scope of authority? Certainly Carter's low leadership rating was, in part, a reaction to his own ambivalence and naivete. That ambivalence, a feature of the Carter administration in general, must also be seen as a reflection of a larger political milieu. In foreign policy carter fell victim to his own perceptions of the world. But he also fell victim to the political environment in which he governed.

The image of Jimmy Carter as a "good man" reflects his honesty, his open morality, and sincere desire to solve the problems that beset the world. He was the "unknown 
candidate," a "slender peanut farmer with sandy hair and gleaming teeth" who had,

run against Washington. . . promising a government as good as the people, in which the President would keep his office door open and never lie. ${ }^{20}$

These personal characteristics were undoubtedly important factors in Carter's election in the post-Watergate era. But these same characteristics tended to work against him once he assumed office. The political realities of foreign policy, of which he had limited experience, conflicted with his conscience; a conflict he was unable to reconcile. As Barnet notes,

Jimmy Carter turned out to be a man who abounded in good qualities he could neither discipline nor integrate. A decent, genuinely moral man, his success in translating his morality into politics was limited. . . . By the end of his term the image of steely determination and managerial competence had given way to one of vacillation and confusion.21

This was evident in Carter's foreign policy. As Barnet continues, "the foreign policy mirrored the man. admirable goals, like his own admirable character traits, collided with one another."22

As the first post-watergate President, Carter's authority was closely scrutinized, under the watchful eye of the public and Congress. Carter's personality obliged the scrutiny. In contrast to Nixon, Carter invited a broad policy input from the Executive and the Legislative branches of government. Although he was obliged to adopt more of a consensus style of policymaking, he seemed naturally 
inclined to rely on his advisors. Because of this style, policies were continually filled with ambiguities and inconsistencies; a natural result of trying to please everyone. As for his own input in foreign policy, Carter had little to offer, relying instead on a "cabinet government."23

Carter understood his own dilemma. In his memoirs, he expressed an uncertainty about the problems he faced as a result of watergate and his own experience as an outsider among washington social circles. He realized Congress would not "embrace me as a long-awaited ally in the Executive Branch."24 Although he benefitted from a Democratic majority in both Houses, his election had been a narrow one.25 As Carter recalls,

I generally doubted that I had a broad public mandate to carry out the programs I had espoused.25

\section{Carter and SALT II}

These characteristics of the Carter administration thus directIy affected U.S. behavior in SALT II negotiations. Though little criticism can be leveled against Carter's desire that SALT be unique (his own formula), the U.S. position in SALT reflected an openness and ambivalence that frustrated America's allies, whose growing perceptions of insecurity demanded consistency and strong leadership from washington. If Carter's foreign policy was predominately influenced by the Trilateral 
Commission (Tricom) as some have claimed,27 then Carter's personal style and the political environment were out of sync with that policy.

Within the first week of his term, Carter ordered preparations for a renewal of SALT negotiations. Over the next several weeks, as Carter turned his attention to other foreign policy matters, SALT was left to the devices of various bureaucratic agencies.28 The end result was the Comprehensive Proposal which went further than the Vladivostok accords by significantly lowering the established ceilings of nuclear weapons.29 Despite the pressures to build an arms agreement on the basis of Vladivostok, Carter was determined to make SALT II his own. He refused to simply "cross the t's and dot the $i$ 's" on a document that was mostly Rissinger's work.30

His campaign was, after all, largely critical of Kissinger, both in negotiating style and his world views. But Carter seemed to go out of his way to avoid actions that may have been likened to the two previous administrations. Ironically, the "openness" and anti-kissinger style proved to be a major source of the contradiction and ambivalence that the Carter administration exuded throughout the remainder of SALT II.

One contradiction arose from the administration's aversion to the use of "linkage" in negotiating style. In part, due to the differences between Kissinger's world views 
and those of Brzezinski's, any linkage of other issues to arms control simply made it more difficult to insulate arms control, and hence, to reach an agreement. The carter administration soon found its policies at odds with one another as Carter's zeal for human rights adversely affected US/Soviet relations and progress in SALT II. ${ }^{31}$

Suspicions of the administration's openness were raised when, shortly before secretary Vance was to present the Comprehensive Proposal to the Soviets in Moscow, Carter announced to the United Nations General Assembly the central features of the Proposal, plus fall back contingencies in the event the Soviet Union rejected it outright. This action may have been a result of the anti-secrecy uprising after Watergate and revelations of certain CIA operations. Carter may have felt he needed to appease the American public and restore some credibility to the Presidency. The primary motivation may have been Carter's own penchant for openness, morality, and honesty.

Ironically, while the motivation was likely a combination of all these factors, the result was a strengthening of political ammunition for an increasing anti-detente sentiment within the United States. The discordant character of the domestic political attitude toward the expectations of the President and toward detente 
simply compounded the political indecisiveness and ambiguity produced by Carter's moral passion to do the "right" thing.

Pressures were mounting to appear tougher with the

Soviet Union. Helmut Schmidt's speech criticizing a US/Soviet arms deal that sacrificed European security pointed up the growing concerns of NATO members. Domestically, pressures from newly created organizations such as the Committee on the Present Danger and Coalition for Peace Through Strength sought to re-address the perceived military weaknesses of the west. Production of the neutron bomb was adopted as the solution to the perceived imbalance in Europe, and as a bargaining chip in SALT. Having pressured West Germany into going along with the neutron bomb production, and possible deployment, Carter suddenly changed his mind and decided to cancel production. Once again perceptions of vacillation and confusion in the administration were the result. Carter simply did not want his administration labeled as one that made bombs "that kill people but leave buildings intact."32

Despite the signals of confusion, to allies and the Soviets alike, negotiations continued. Hopes were high for a summit meeting by summer 1978. With an upcoming Congressional election, however, there were hopes, even among those senators in favor of SALT, that a treaty ratification debate could be delayed until after the election. As Vance suggests, there was a strong feeling 
among pro-SALT Senators that their re-election rested, in part, on taking a harder line on soviet policy 3

\section{Failure to Ratify SALT II}

The achievement of a SALT treaty in June 1979, followed by the failure of the U.S. Senate to ratify it, should not seem too surprising given the confusion and incoherence in Carter's foreign policy. On the one hand, the moral motivation to seek arms control, and the hopes that it would ensure a more trusting relationship between the superpowers, helped to overcome the many negotiating obstacles leading to an agreement. On the other hand, the anti-detente forces in the United states, strengthened by Soviet actions in Cuba and Afghanistan, had the effect of neutralizing any real trust between the two countries that the conclusion of the treaty may have provided. ${ }^{34}$

Secretary Vance made clear the administration's desire for SALT II ratification when he stressed the need to appease the Senate.

If Carter would decide to deploy the MX in a mobile basing mode, agree to an increase in the defense budget, and acquiesce in several conditions acceptable to the administration in the Resolution of Ratifications he would satisfy many of the critics.35

Vance argued that SALT II ratification failed not because of "fatal flaws" in the treaty itself, but because the opponents were successful in linking the treaty to the need to restrain soviet actions in other countries. ${ }^{36}$ 
Carter testifies to this argument in his memoirs, citing "the antagonism that Soviet action in Afghanistan had kindled in our country."37

Rather than continue to pursue arms control for its own sake, moral or strategic, Carter had bowed to the linkage of SALT II and Afghanistan, a linkage for which he blames Congress. However, in a television speech on 4 January 1980 Carter stated that "the world simply cannot stand by and permit the Soviet Union to commit this act with impunity. Neither the United states nor any other nation - . can continue to do business as usual with the soviet Union." 38

Carter had suddenly switched positions, joining those same critics who had argued that arms control must be used as a "carrot" to moderate soviet behavior elsewhere. But 1980 was also an election year, and carter had decided not to risk defeat by pursuing an arms agreement he believed was the "most detailed, far-reaching, comprehensive treaty in the history of arms control," and an ". . . absolute indispensable precondition for moving on to. . more significant cuts under SALT III."39

Rather than appearing as if "I'm down in the trenches fighting for my political life,"40 during the 1980 campaign, Carter withdrew the SALT ratification vote from the senate. Consistent with the characterization of his administration as one of vacillation, ambivalence, and ambiguity, Carter 
then imposed a U.S. grain embargo on the Soviet Union, further appeasing Soviet hard-liners in Congress, while isolating one of his natural constituents--the farmer.

\section{Brezhnev (1973-1979)}

Throughout SALT II Brezhnev retained his position as the undisputed head of the communist party and as leader of the Soviet Union. The durability of his authority, however, rested not only on his ability to manage competing interests, but also on the success of ambitious domestic programs that relied heavily on factors not completely within his power to control. Perhaps the most important factor for Brezhnev was the continuation of detente. Domestic programs to improve consumer satisfaction and economic efficiency relied on favorable weather conditions for agricultural production, clearly a factor not within his control. Detente, however, was a somewhat more controllable factor. It was deemed essential to economic improvement since it was intended to provide the availability of Western capital, credit, technology, not to mention a more relaxed political atmosphere in which concentration on domestic programs could be more easily afforded.

Both the weather and detente proved mostly favorable for the success of Brezhnev's programs in the first years of SALT II. Record harvests were recorded in 1973 and again in 1976. Detente produced new trade agreements with the United 
States, Western Europe, and Japan. On the negative side, however, the Jackson-Vanik amendment linking U.S. credits and trade to soviet emigration policy, plus a severe drought in 1975, strengthened the position of Brezhnev's critics within the top leadership.

\section{Brezhnev's Detente Policy}

Following the Twenty-Fifth Party Congress in February 1976, Brezhnev's position emerged unchallenged. But it does seem likely that by 1976 there was serious doubt about both his ability to govern and the credibility of detente. The result of the SALT I debate among the party leadership in 1971 was a tentative compromise between pro-detente forces and the more orthodox ideologues. In exchange for support for his programs, Brezhnev was obliged to allow an increasingly broader participation of views in decisionmaking. In 1971 no Politburo position belonged to a ranking member of either the military or state security.41 By 1973 Marshall A. Grechko, the Minister of Defense, and Y. Andropov, Chairman of the KGB, were elevated to full Politburo status. Ustinov was later promoted to full membership in 1976.42

The detente atmosphere began showing clear signs of erosion by 1976. Brezhnev's ability to rule was further put in question after he suffered a stroke in 1975 and was absent from office for several months. Despite the setbacks 
Brezhnev remained committed to detente, "determined to push forward with an increasing dependence on foreign sources of capital, technology, and consumer goods."43 He responded to political challenges against him with moves to reinstate and consolidate his own power.44 By 1980, as Breslauer concludes, Brezhnev assured himself of "near-total consensus of perspectives" among the top leadership.49

\section{Brezhnev and SALT II}

Because of detente's key role in Brezhnev's domestic policies, it should not be surprising that there is some parallel between the leadership characteristics of the Brezhnev regime and Soviet behavior in arms control during SALT II. The first years following SALT I were marked by internal support for Brezhnev's policies, as well as the overall success of those policies. Amidst expanding trade and easing soviet threat perceptions in the West, SALT proceeded smoothly through the 1973 summit and the vladivostok agreements in 1974.

The mid-SALT II period, however, was offset by a toughening of the soviet negotiating position and subsequent stagnation period. This behavior corresponds to accommodations by Brezhnev to allow ranking military and state security members into the highest policymaking positions. It also corresponds to the weakening of Brezhnev's position following his stroke in 1975. In 
addition, Soviet behavior must also be seen as reacting to U.S. politics, the succession of leadership, the rise of anti-detente attitudes, and Carter's human rights campaign. These factors could only have bolstered Brezhnev's critics, forcing a more cautious, tougher arms control position.

The latter SALT II period coincides with Brezhnev's power consolidation in reaction to signs of failure with detente and its relation to the success of domestic programs. More military and traditionalist pressure at this time likely had the effect of compromising Brezhnev's detente policy for direct involvement in Afghanistan, Cuba, and a more rapid buildup of $5 s-20$ missiles. Brezhnev's signature on SALT II must be seen then as a demonstration of his efforts at that time to re-establish his authority and to revive detente. Within the Party leadership, Brezhnev was moved to demonstrate to the "traditionalists" that the "realist" policy of detente was still the most viable solution to the domestic and foreign interests of the soviet Union. 46

\section{THE SUBSYSTEM VARIABLES}

SALT II began in an atmosphere of East/West cooperation (see Appendix Table V). To be sure, the fact that the conclusion of the SALT I agreements helped establish an optimistic beginning for SALT II cannot be ignored. The signing of SALT I codified the US/Soviet 
detente, and greatly contributed to furthering the West European/Soviet detente. But while there was, as yet, no cause for alarm in alliance relations (see Appendix Table v), the implications for the alliance in an atmosphere of detente were of some concern. The United States had negotiated and concluded an arms control agreement with the Soviet Union thus alleviating West European concerns about their own detente with the East. But would an expanded and more durable detente lead to a less dependent Western Europe on the United States, and instead, to closer ties and dependence on the Soviet Union? Could the two adversarial relationships, with their distinct interpretations of detente, maintain an environment of cooperation without negatively affecting alliance unity? SALT II became the forum both for testing alliance unity and detente.

\section{The Test of Detente}

In the 1970 s detente and changing West European security perceptions created a dilemma for U.S. and soviet policy in SALT II. Both arms control and detente are policies designed to maximize security by means of mutual restraint and cooperation. From the subsystem perspective, however, detente is afforded a different meaning to each actor. For the West, detente was never intended to carry adversarial cooperation to the point of alliance dissolution, though it sought to accommodate some west 
European independence from the United States. For the most part, the American interpretation of detente was for both superpowers, through bilateral arrangements, "to act responsibly," and "not to try to change the balance of power through unilateral action."47

For the Soviets, detente sought to maximize tensions within the alliance and constrain American resolve against an expanded role in international affairs. As Ulam has explained Soviet policy, "detente is a process rather than a specific agreement, or sets of agreements."48 Arms control agreements merely perpetuate detente so that broader goals may be realized. Within Hassner's offensive/defensive framework for Soviet policy, the soviets sought to make unilateral gains as long as they perceived the West as divided and weak, and the United states unwilling or unable to provide the leadership necessary for alliance unity. ${ }^{49}$ Griffiths draws a similar conclusion. From his analysis involving the domination of an "activist trend" within the Soviet leadership, detente, as a policy of limited cooperation,

serves as an effective form of conflict in that it creates an East-West climate favouring the exacerbation of internal differences within NATO, the defection of support for high levels of defense preparedness in the United states and Western Europe, and a reluctance on the part of Western governments to take action in local conflicts that jeopardizes the prospects for cooperation with the East. . . .50

For the Soviet Union, detente, via SALT, served as the 
"diplomatic route" to an improved international position. SALT served to disrupt alliance cohesion by acting upon West European concerns, and America's dilemma in dealing with them. This included continued cooperation with the United States, encouraging tensions between Western Europe and the United states, and accommodating a separate West EuropeanSoviet detente. Within the context of the alliance dilemma mentioned above, a dilemma for soviet policy exists in much the same way as it does for the United states. West European fears of abandonment or entrapment may actually encourage alliance unity rather than disunity if soviet actions are perceived as threatening west European security. This is the case whether soviet policy emphasizes cooperation or conflict with the United States.

\section{Changed West European Security Concerns}

Much of SALT II can be viewed in the context of the opportunities and dilemmas that faced each actor as their security policies evolved during the 1970s. As the subsystem data support, the period of SALT II was accompanied by a general trend toward worsening adversarial relations (refer to Table VI in the Appendix, and Figure 2). SALT II reflected those trends.

The continuation of the detente in which SALT II began was recognized by many as a major test for alliance unity. Concerned about unity, U.S. policy in 1973 stressed the 
reaffirmation of its relations with western Europe. As Kissinger stated,

We had decided to make 1973 the Year of Europe, to reaffirm our alliance ties with the Atlantic Community--and also Japan. We would show that these ties were stronger and deeper than the tentative new relations with Communist countries. On the basis of Alliance cohesion and vitality we would test the real opportunities for detente.51

Over the next few years alliance relations were severely tested. As soviet policy took advantage of strained alliance relations, not to mention soviet perceptions of American weakness in Vietnam, SALT II, in turn was significantly affected. In 1973, the United States and the Soviet Union continued to expand areas of cooperation with nine separate agreements being signed during the Nixon-Brezhnev summit meeting that summer. But while West Europeans generally welcomed arms control efforts, they viewed the fact that SALT II would be based on maintaining a strategic balance in mutual destructive capability with great caution. Without America's nuclear guarantee to rely on, they saw themselves more vulnerable to a soviet threat, if not militarily, then certainly politically.

One of the nine bilateral agreements signed during the summit, the Agreement on the Prevention of Nuclear War, "implied that the United States was more interested in Soviet-American arms control than its security commitment to NATO."52 The risk of nuclear destruction may have been 
lessened somewhat by the agreement, but the extended nuclear guarantee to Western Europe was based on a "non-commitment" to a no first-use strategy. This agreement seemed to undermine that strategy.

other events in the early 1970 s further contributed to the erosion of Atlantic relations. In October 1973 the Arab oil embargo and the Israeli-Egyptian conflict highlighted the differences in strategic interests between the United States and Western Europe. Because of the disparity in dependence on OPEC Oil, no common alliance action could be arranged. In lieu of a U.S. proposal for a countercoalition to OPEC, Western Europeans, seeing such an action as too great a risk, rushed to make bilateral deals with individual OPEC nations. Disagreement also arose over the issue of West European cooperation with the United States and its policy to aid Israel.53 still further anxieties developed over the lack of consultations or even an advance notice from the United states during the military alert of October 25 th. 54

\section{Soviet and U.S. Reaction}

Following the climactic summit of 1973 SALT II negotiations stagnated until November 1974. During that time Soviet policy appeared all too willing to make demands on the United states that might create further divisions among NATO allies and force U.S. concessions in the arms 
talks. Beside the speculative, perhaps more obvious motive to restrain potential Chinese nuclear capabilities, the Agreement on the Prevention of Nuclear War was also aimed at fueling West European concerns of abandonment. Beyond that, the Soviet Union continued to push the issue of American forward-based systems in Europe as it had during SALT I.

At the Vladivostok meeting in November 1974, the Soviets dropped their FBS demand but acquired a U.S. agreement not to press for the inclusion of a soviet cutback in "heavy" missiles. From the subsystem perspective, the FBS issue must be seen as more than simply a soviet bargaining chip in arms control negotiations. By remaining adamant on their FBS position the soviets might have held out for U.S. concessions that sacrificed West European security. Indeed, the political gains from such a concession could have outweighed any quantitative or qualitative strategic arms Iimitation that the United states might have conceded.

The United States, however, did not retreat from its promise to the allies not to negotiate weapons systems committed to the European theater. Such a stalemate in negotiations over the FBS issue would only have frustrated SALT II, and the Soviets required progress in arms control in order to keep detente alive.

Because of the desire for continuity in detente, the Ford-Brezhnev meeting in vladivostok, and the agreements 
that accompanied it, were of no great surprise. For their own reasons, both the Ford administration and the Brezhnev regime were anxious to keep detente and arms control alive. Besides the agreed-upon ceilings for offensive systems, a new deadiine for a SALT II treaty was set for 1975. SALT II had entered into a new phase with the basis of a treaty established at Vladivostok. Beneath this accomplishment, however, lay deeper political motivations and intentions.

Despite the emerging criticisms of detente within the United states, and the political setback resulting from the Jackson-Vanik amendment, the soviet Union perceived its position in the world to be strengthening, while the West continued to show signs of weakness and disarray.

Watergate, the U.S. withdrawal from Vietnam, disunity in NATO over issues in Cyprus, spain, and Portugal, and the economic and energy crises, all gave credence to soviet perceptions that the "correlation of forces" had swung in their favor.ss At the same time, soviet policy continued to nurture its detente with Western Europe vis-a-vis the Conference on security and Cooperation in Europe (CSCE), and talks on Mutual and Balanced Force Reduction (MBFR).

Two major obstacles to SALT II came to the foreground as a result of the change, or perceived changes, in the international environment. These were the Backfire bomber and the cruise missile. As was discussed earlier, the problem was one of definition; the weapons systems were 
somewhere between strategic and tactical--in the "gray area" of arms control. The vladivostok agreements had placed heavy bombers (strategic) under the 2400 launcher ceiling. This included the American B-52 and the Soviet Mya-4 and Tu20 (the Bison and the Bear). The U.S. F-111 was deployed in Europe, thus outside SALT II limitations. The B-1 was, as yet, in the developmental stages. The Backfire's characteristics, however, such as length, weight, wingspan, range, and payload, placed it in the gray area between medium and heavy. Although the soviets claimed its intentions were for theater operations only, the Backfire had strategic capabilities. 36

The Vladivostok agreements did not mention cruise missiles per se, although an agreement was made to include ballistic air-to-surface missiles of a range exceeding 600 $\mathrm{km}$. under the 2400 launcher ceiling.57 Following Vladivostok, the Soviets interpreted the agreement as including cruise missiles, whereas the United states insisted upon no limitations.58

As Burt suggests, one of the possible motivations of the Soviets in demanding that all cruise missiles be limited was to restrict its potential deployment in a tactical, or European mode.39 Because of the difficulty in cruise missile verification, any treaty would most likely have to count strategic and tactical deployments together. In this manner, the soviets would have gained restrictions on 
American FBS, thus feeding West European concerns of abandonment. At the same time, the Soviets would have been free to deploy the Backfire in a tactical mode, thus strengthening their European position, militarily and politically.

Consistent with this thesis of soviet motivation in SALT II was a rejection on their part in November 1975 of a U.S. compromise proposal to count both the cruise and Backfire "against one another in equal numbers above the 2400 level under an additional ceiling of 200-300."60 This ceiling would have only applied to longer range missiles and not to tactical versions. Throughout 1975, therefore, SALT II was inflicted with paralysis due to soviet willingness to push for greater political gains encouraged by disunity within the United States, and between alliance partners.

\section{The Decline of Detente}

The era of detente had already reached its peak by 1971 (see Figure 2) and by 1974 US/Soviet cooperation turned steadily toward conflict (see Appendix Tables VIII-XIII). Alliance relations stabilized somewhat by 1976 (see Figure 2) and a greater sense of unity was restored amidst a renewed Western resolve against an increasing soviet threat perception, particularly in Western Europe.

In the 1976 Presidential campaign, detente became a term that was no longer politically advantageous to use. By 
1978 Western Europe was in "open opposition" to SALT II and its implicit disregard for European security.61 NATO also agreed on the necessity to counter the buildup of soviet forces in Europe, 62 particularly in light of continued Soviet deployments of the ss-20.63

By the late 1970s, soviet policy was being forced to adapt to a changed environment. Western Europe was now asking the United States to readdress a perceived imbalance in Europe, which US/Soviet cooperation had failed to deal with. Supported by European fears, anti-detente forces in the United States were quick to adopt measures to deploy new weapons in Europe. The cruise missile, primarily a bargaining chip for Carter, was now seen as essential for European deployment. A new missile, the Pershing II, also was earmarked for Europe.

In April 1978, the Soviets dropped their demand that weapons technology transfer be banned. In its place, a circumvention clause, favored by the United States, was used. In May the Soviets accepted a freeze on the number of warheads allowed per missile, and in July further compromises were worked out. In December, the United States demanded the inclusion of a soviet statement committing the Backfire to tactical usage only. A compromise was also reached on cruise missiles.

In June 1979 SALT II was signed, though largely a result of changed political relationships. The two-track 
decision of NATO re-established an alliance unity, albeit an ambiguous one, ${ }^{64}$ not realized since the early 1970 s.

\section{CONCLUSION}

As US/Soviet relations remained generally positive for the first few years after the signing of SALT I, it is interesting to note the coincidence between the negotiations and signing of SALT II, and the gradual decline of US/Soviet cooperation through the mid and latter 1970s. If the same argument is used that SALT was the keystone of detente, SALT II should have preserved, or even rejuvenated, positive US/Soviet relations.

From the domestic perspective, it might be argued that it was the Carter administration's mishandling of arms control, bad negotiating, and misjudgment of soviet intentions which brought about the strong reaction to detente. Again the argument is only partially correct. The subsystem perspective shows that the decline of detente and the failure of SALT II to be ratified were also due to changes in security perceptions. The soviet buildup of SS20 s and failure of SALT II to address European security concerns testifies to the fact that alliance solidarity was being weakened by East/West detente. Demands were then made, not for arms control, but for new arms deployments. While the Carter-Brezhnev summit in 1979 was highlighted by the signing of SALT II, NATO leaders and the United states 
Congress were addressing concerns over American abandonment of Western Europe.

The blame for the failure of SALT II, therefore, partly lies in the inability to have foreseen the possible or likely effects of detente from the viewpoint of the subsystem perspective.

Not only did detente test alliance relations, but US/Soviet relations tested the durability of detente. Both domestic and subsystem factors played significant roles. The momentum of detente and SALT I carried over into 1974 even as alliance unity was strained by the Arab oil embargo, the Israeli-Egyptian War, and Nixon's resignation. By the time of the vladivostok meeting in 1974, all three relationships were on a positive trend (see Figure 2). Following Vladivostok, however, US/Soviet relations steadily declined while alliance relations vacillated up and down reflecting both growing concerns of abandonment and ambiguity and confusion in U.S. policy.

The level of West European/Soviet cooperation fell as Western Europe became more fearful of Soviet intentions. An interesting observation is that US/Soviet and alliance relations parallel each other through 1975, then run counter through 1979 (see Figure 2). This suggests both West European confusion over U.S. policy and U.S. confusion over alliance policy after 1975. It also suggests that the detente in US/Soviet relations declined as alliance unity 
became strained by West European perceptions of abandonment. In addition, whereas it was West European/Soviet relations that ran counter to US/Soviet and alliance relations from 1969 to 1974, from 1975 through 1979 alliance relations generally ran counter to US/Soviet and West European/Soviet relations (see Figure 2). While US/Soviet relations turned toward confrontation, both sides' domestic policies held to a desire for a SALT II treaty. Western Europe was then experiencing a period of confusion. Security perceptions of entrapment (that arms control efforts were giving way to confrontation) were mixed with perceptions of abandonment (that a SALT II treaty would constrain or remove the U.S. commitment to Europe). Alliance unity was supported both by US/Soviet cooperation in arms control negotiations (flexibility and compromise) and US/Soviet confrontation (impasse in arms control due to uncompromising positions in questions regarding European security). Consequently, alliance relations turned downward following Schmidt's speech criticizing SALT II for failing to address European concerns, and following the signing of SALT II.

Both U.S. and Soviet domestic policies favored the signing of SALT II, but not enough in the United states for ratification. The environment in which SALT II was negotiated was one of growing confrontation in US/Soviet and West European/Soviet relations, and confusion in alliance relations. The alliance called for new arms control 
negotiations to address concerns of entrapment, then called for reassurance from the Unites states to address concerns of abandonment.

If detente was a major test of alliance unity, so too detente was a test for arms control. Whereas changes in NATO security perceptions prompted a re-evaluation of detente, the success of SALT II likewise succumbed to the call for alliance unity. 


\section{CHAPTER III NOTES}

'The primary sources referenced in this section are, Strobe Talbott, Endgame: The Inside Story of SALT II (N.Y.: Harper and Row, 1979); Cyrus Vance, Hard Choices (N.Y.: Simon and Schuster, 1983); and, Jan M. Lodal, "SALT II and American Security," Foreign Affairs (No. 67, Winter, 197879).

${ }^{2}$ The SALT I Interim freeze set Soviet MLBMs at 300 and those of the United States at zero. This limitation, however, was widely regarded as a soviet concession since U.S. strategy did not rely on "heavy" missiles.

${ }^{3}$ The Interim Agreement, sponsored by Senator Henry Jackson, was amended to include this congressional mandate. For key excerpts of the senate debate on this amendment and Senate approval of the Interim Agreement see, "Senate Debate on Jackson Amendment to Public Law 92-448, August and September 1972," in Roger P. Labrie, ed. , SALT Handbook: Rey Documents and Issues 1972-1979 (Washington D.C.: American Enterprise Institute for Public Policy Research, 1979), pp. 144-145; and, "Public Law 92-448 Approving the Interim agreement, 30 September 1972," Ibid., pp. 141-143.

4hereas the cruise missile was not a new development, technological advances prompted new interest in the utility of the cruise in the mid-1970s. For an informative discussion of this weapon and its implications for arms control see, for example, Richard Burt, "The Cruise Missile and Arms Control," Survival (Vol. 18, January/February 1976).

"The "gray area" of arms control refers to weapons systems that cannot clearly be defined as strategic or tactical. For a discussion of the implications of gray area systems on arms control and alliance relations see, for example, Gregory F. Treverton, "Nuclear Weapons and the 'Gray Area'," Foreign Affairs (Vol. 57, Summer 1979).

${ }^{6}$ Talbott, Endgame: The Inside Story of SALT II, pp. $36-37$.

7One of the more difficult issues of SALT II was determining the range limit of a cruise missile due to the ability to alter its flight pattern. The straight line limit, preferred by the soviets, measured the "as the crow flies" distance from launch point to target. The United States favored maximizing the missile's range limit to include the total distance covered by its flight path as it weaved and dodged over the terrain. In the final treaty both sides agreed to a straight line limit. 
${ }^{8}$ For an interesting inside account of the ratification debate on SALT II see, Vance, Hard Choices, Chapter 16, "The SALT Debate."

9 Statistical Abstract of the United States 1982-1983, "Vote Cast for President," (Washington D.C.: U.S. Bureau of the Census, 1982), p. 472.

McGovern took 37.5 percent of the popular vote and 17 electoral votes while Nixon took 60.7 percent of the popular vote and 520 electoral votes.

10 The Gallup Opinion Index (No. 95, May 1973), pp. 14 ; and, (No. 98, August 1973), pp. 1-4.

11Richard Barnet, The Alliance (New York: Simon and Schuster, 1983), p. 340 .

12 Ibid. , p. 357 .

13 Gerald Ford, A Time to Heal (New York: Harper and Row, 1979), p. 33 .

14 Statistical Abstract of the United States 1982-1983, "Composition of Congress," p. 483 .

15 Barnet, The Alliance, p. 357.

${ }^{16}$ Ford, A Time to Heal, p. 345 .

17 See, for example, Ford's comments regarding the usage of "detente" in James $M$. Naughton, "Ford Says "in time' He Expects to Talk with Nixon on China," The New York Times (March 2, 1976), p. 12 . p. 37 .

${ }^{18} \mathrm{Talbott}$, Endgame: The Inside Story of SALT II,

19 The Gallup Opinion Index (No. 183, December 1980), pp. 56-57; and, Fred I. Greenstein, ed., The Reagan Presidency: An Early Assessment (Baltimore: Johns Hopkins University Press, 1983), pp. 14-15.

20 Barnet, The Alliance, p. 357.

22 Ibid., p. 364 .

22 Ibid., p. 365 .

${ }^{23}$ Talbott, Endgame: The Inside Story of SALT II, pp. 41-42. 
24 Jimmy Carter, Reeping Faith (New York: Bantam Books, Inc., 1982), p. 68 .

25 Statistical Abstract of the United States 1985 , p. 245. In the 1976 election Carter took 50.1 percent of the popular vote compared to Ford's 48 percent. The 95 th Congress, which convened in 1977, included 292 Democrats and 143 Republicans in the House; 61 Democrats, 38 Republicans, and 1 other, in the senate.

26 Carter, Reeping Faith, p. 68.

${ }^{27}$ See, for example, Laurence $H$. Shoup, The Carter Presidency and Beyond: Power and Politics in the 1980s (Palo Alto, Ca: Ramparts Press, 1980).

p. 43 .

28Talbott, Endgame: The Inside Story of SALT II,

${ }^{29}$ Refer to the discussion in this chapter on the Comprehensive Proposal in "Issues of SALT II," p. 54.

30 Talbott, Endgame: The Inside Story of SALT II, pp. 49-50.

31 Brezhnev had made clear in several speeches the Soviet Union's ire over Carter's human rights zealousness. Actions such as Carter's letter to Soviet scientist Andrei Sakharov and Carter's invitation to Soviet dissident Bukovsky to the White House were seen by the Soviets as a clear threat to detente.

32 Barnet, The Alliance, p. 376 .

${ }^{33}$ Vance, Hard Choices, p. 100.

${ }^{34}$ During the summer of 1979, as senate hearings on SALT II were in progress, U.S. intelligence discovered a Soviet combat brigade in Cuba. Later, in December 1979, as the Senate was preparing to bring SALT II ratification to a vote, Soviet troops entered Afghanistan.

35 Vance, Hard Choices, p. 357 .

${ }^{36}$ Ibid. , pp. 349-350.

${ }^{37}$ Carter, Reeping Faith, p. 265.

${ }^{38}$ Hamilton Jordan, Crisis: The Last Year of the Carter Presidency (New York: G.P. Putnam's Sons, 1982), p. 100.

${ }^{39}$ Carter, Reeping Faith, pp. 261-262. 
40 Jordan, Crisis: The Last Year of the Carter

Presidency, p. 100 .

41Following the 24 th Party Congress, Dmitri Ustinov, Central Committee Secretary for Defense, the defense industry and the police, retained only candidate member status in the Politburo.

42 Jerry F. Hough and Merle Fainsod, How the Soviet Union is Governed (Cambridge, Mass.: Harvard University Press, 1980), pp. 470-471.

${ }^{43}$ George A. Breslauer, Rhrushchev and Brezhnev as Leaders: Building Authority in Soviet Politics (London: George Allen and Unwin, Ltd., 1982), p. 222 .

44 Several associates of Brezhnev were elevated in position while others were demoted. $K$. Chernenko was elected to full Politburo status while N. Tikhonov was elected to candidate status. In $1977 \mathrm{~V}$. Ruznetsov was made First Deputy Chairman of the Presidium of the Supreme Soviet. N. Podgorny was purged from his Politburo position. In $1978 \mathrm{~K}$. Mazurov was removed from office. In 1980 the resignation and death of $A$. Rosygin provided the opportunity for the promotion of Tikhonov to full member Politburo status.

Brezhnev also augmented his own list of titles taking the position of Marshall of the Soviet Union in 1976, and Chairman of the Presidium of the Supreme Soviet in 1977.

4"Breslauer, Khrushchev and Brezhnev as Leaders: Building Authority in Soviet Politics, p. 231.

${ }^{46}$ See, John Lenczowski, Soviet Perceptions of U.S. Foreign Policy (London: Cornell University Press, 1982), Chapter 7, "Traditionalists and Realists."

${ }^{4}$ Adam Ulam, "Detente under Soviet Eyes," Foreign Policy (No. 24, Fall 1976), p. 155.

${ }^{48}$ Ibid., p. 155 .

49 See, Pierre Hassner, "Moscow and the Western Alliance," Problems of Communism (May-June 1981).

${ }^{30}$ Franklyn Griffiths, "Cooperation as a Form of Conflict: The Soviet Approach," NATO Review (Vol. 22, No. 5, October 1974), p. 18.

91 Henry Kissinger, The White House Years (Boston: Little, Brown, and Co., 1979), p. 1474; for additional 
discussion see, for example, Michael Howard, "NATO and the Year of Europe," Survival (January-February 1974).

$32 \mathrm{Jane}$ M.O. Sharp. "Arms Control and Alliance Commitments," Political Science Quarterly (Vol. 100, No. 4,

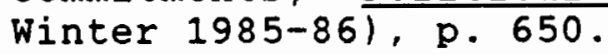

${ }^{3}$ See, for example, Leslie H. Gelb, "U.S. Jets for Israel Took Route Around Some Allies," The New York Times (October 25, 1973), p. 1; and, "Bonn Bids U.S. Halt Arms to Israel," The New York Times (October 26, 1973), p. 20.

${ }^{34}$ See, for example, Alvin Shuster, "Alert Puzzles Europeans," The New York Times (October 27, 1973), p. 1; and, David Binder, "Kissinger Said to Express Disgust at Allies' Position," The New York Times (October 31, 1973), p. 1 .

35 The Soviet term "correlation of forces" is given a much broader interpretation than the Western term "balance of power." In the struggle between Capitalism and Socialism it refers not only to some balance of military power, but includes economic, social, and political factors as well. For a brief discussion of Soviet usage of the term see, for example, Lenczowski, Soviet Perceptions of U.S. Foreign Policy, pp. 16-26.

96 The Backfire, for instance, could be refueled in mid-air for intercontinental missions.

57Lodal, "SALT II and American Security," p. $247 \mathrm{n}$.

${ }^{38}$ Burt, "The Cruise Missile and Arms Control," p. 13.

s9 Ibid., p. 13.

60Ibid., p. 13.

61 See, Helmut Schmidt, "The 1977 Alastair Buchan Memorial Lecture," Survival (January-February 1978), pp. 210 .

62 North Atlantic Council Meeting with Participation of Heads of State and Government--31 May 1978, Final Communique," in NATO Handbook (NATO Informational Services, Paris, 1979), p. 91.

${ }^{63}$ For technical data and discussion of the strategic implications of the SS-20 missile see, for example, Gerhard Wettig, "The Soviet INF Data Critically Reviewed," Aussen Politik (Vol. 34, January 1983). 
64 A great deal of ambiguity existed in the two-track decision as a result of West European anxiety and trying to have it (security) both ways. Western Europe wanted detente and arms control to continue but also wanted a renewed U.S. commitment to European defense. West Europeans felt that U.S. missiles might not have to be deployed whereas the United states was becoming more committed to deployment and more reluctant toward arms control. 
CHAPTER IV

INF / START

\section{THE ISSUES OF INF/START}

The Intermediate Nuclear Forces (INF) and the Strategic Arms Reduction Talks (START) arms control negotiations were born out of SALT. But they marked a new chapter in US/Soviet arms control. For the most part, both the INF and START talks were conditioned by a pre-set deadline. The 1979 NATO "dual track" decision had dictated the end of 1983 as the date to begin deployment of Pershing and cruise missiles in Western Europe.1 From the outset the INF component of the negotiations took priority, with the success of START relying on positive results in INF. START, as it now appears, never had a chance as it succumbed to the same fate as INF in 1983.

Unlike SALT, theater nuclear forces and strategic forces were divided into separate forums. Though this arms control regime is largely associated with the Reagan administration, the INF talks actually began just prior to Reagan's election in 1980. The fundamental issues on which those talks would be based were actually a product of what 
SALT succeeded or failed to do. The START negotiations, on the other hand, did not begin until the summer of 1982 .

\section{INF}

The first round of INF took place in Geneva and was primarily an introductory meeting. The soviets, for the most part, came to listen while the United states presented guidelines based on the Integrated Defense Document (IDD), a NATO communique issued in December 1979.2 The primary task of the U.S. delegation was not so much to deal with those gray area weapons that had been so difficult in SALT, but to respond to the recent deployments of soviet intermediaterange missiles.

The Soviet position, once those missiles were installed, was that a balance had been achieved in theater nuclear forces. The U.S. position, however, saw INF as the necessary forum in which to redress the imbalance caused by the soviet deployments. In the first round of talks, therefore, the United States was already looking to at least a partial deployment of new U.S. missiles in Europe.

The purpose of the negotiation side of the "dual track" decision was to compliment partial deployment of Pershing II and cruise missiles by offering a reduction in the number of missiles deployed in exchange for a reduction in the number of soviet ss-20s. What this meant was that the United States was treating the December 1983 deadine 
for deployment as if the missiles were already in place. The bargaining chip was the promise, or threat, to deploy new missiles rather than to remove existing weapons. Ideally, of course, it was hoped that negotiations would preclude new deployments in Western Europe. This was the idea behind the IDD decision. Although an anti-arms control attitude characterized the Reagan administration, a commitment was made to the "dual track" decision soon after Reagan took office. ${ }^{3}$

The Reagan administration, however, did not actually begin formal negotiations on INF until late 1981. During an NSC meeting on 12 November the decision was made to base the U.S. negotiating position on the lowest possible equal ceilings in intermediate-range weapons, preferably zero. 4 On November 18 th President Reagan officially announced the "zero option" in a National Press Club speech." The projected deployment of NATO missiles would be cancelled in exchange for the dismantling of all Soviet SS-20s, SS-4s, and ss-5s.

The Soviet position, however, was quite different. Since they claimed that a balance existed since 1979, any reduction or limitation of forces must include weapons already deployed, namely British and French forces, and U.S. forward-based systems in Europe. The Soviets also called for a complete moratorium on intermediate-range missile deployments until a treaty could be concluded. Total "zero" 
for the Soviet Union was possible as long as it meant moving closer to making Europe a nuclear free zone. And, if not a complete removal of nuclear forces, then a limit should be placed on all those weapons over one thousand kilometers in range. Such a limit was not without significance, as it would most have affected U.S. forward-based systems and U.S. forces outside Europe but part of NATO defense.

Both the U.S. and the Soviet positions were far from any common grounds for agreement. The problem was that both sides had totally different ideas of the military balance in Europe, and that they adhered to different measurements of that balance. ${ }^{6}$ The Soviets insisted on counting British and French systems while disregarding East bloc systems outside Europe (i.e., weapons in European Russia). The United States disregarded British and French systems and counted all Soviet systems in Eastern Europe.

The Soviets counted U.S. aircraft carriers in the Mediterranean and the North Atlantic when considering the potential range of aircraft. Yet they disregarded their own Badger, Blinder, and Backfire bombers stationed outside European Russia, but having the capability to strike western Europe. The Soviets also chose to count Launchers rather than warheads, disregarding the three warhead capability, and the mobility of the $\mathrm{sS}-20$. The launcher's reloading capability also gave the ss-20 a second-strike potential, 
another qualitative factor not surprisingly missing from their count.

Not surprisingly too was the soviet goal to prevent the planned NATO deployment. In Geneva for the second round of talks (the first under the Reagan administration), U.S. delegation leader Paul Nitze laid out the rationale for the zero option, but provided no real details of a treaty. The Soviet team came to reiterate Brezhnev's proposal, a four point plan which included an immediate moratorium on mediumrange $(1,000-5,500 \mathrm{~km}$.$) weapons in Europe, negotiations$ toward reductions in those weapons, eventual reduction to zero of all medium-range weapons, and eventual reduction to zero of all short-range and tactical nuclear weapons. Included in this plan was a document on how this proposal was to be implemented. European forces (Including the British and French) only would be counted. The United States, on the other hand, called for global ceilings, covering Soviet missiles in Asia that could be re-deployed if need be in Western Russia, or vice versa. With very little to agree on, negotiations were recessed in time for Christmas.

Returning to Geneva in February 1982, the U.S. team presented a draft treaty based on the zero option. Nitze's counterpart, Yuli Rvitsinsky, tabled a document entitled "Statement of Intentions," the essence of which stated that the negotiations should produce an agreement that would 
follow the Soviet version of the zero option--zero Pershing II and cruise missiles. It also reiterated their willingness to reduce to zero, matching only British and French systems. Each side rejected the other's proposals. The fourth round of talks began in May 1982 with neither side moving from their previous positions. The Soviets presented a draft treaty of their own, although it merely added a few details to their statement of Intentions proposal. They did indicate some flexibility on including SS-20s deployed east of the Urals in a treaty. The inclusion of these missiles, however, had to be precluded by a moratorium on further deployments, the key requirement of the Soviet position. This brought the negotiations back to the main obstacle, the deployment of Pershing and cruise missiles in Europe. By the summer of 1982, therefore, the talks had reached an impasse.

At the negotiating table the Soviets had been hinting for some time that they would pull out of the talks if the United states proceeded with the 1983 deployment schedule. They had also hinted at possible counter-measures such as new deployments of their own. Indeed, early in 1984 such counter-measures were reported.?

Acting on his own, and motivated by political pressures to break the impasse and reach an agreement before the deployment date, chief U.S. negotiator Paul Nitze attempted a compromise solution. ${ }^{8}$ During the summer of 1982 
he decided to discuss such a solution one on one with his counterpart, Kvitsinsky. The proposed solution, the "walk in the woods," as it came to be called, was an agreed-upon compromise which each ambassador would present to their respective governments. Calling it a "joint exploratory package," such an agreement would have compromised several key issues.

The Soviets would have allowed new U.S. weapons in Europe. The pershings would not be deployed but cruise missiles would be acceptable. The Soviets would also give up their insistence for compensation if British and French forces were not included, as had been their position in SALT. Soviet plans for their own cruise missiles would also be scrapped. The United states would sacrifice deployment of the Pershing II (The Soviets were more adamant about preventing deployment of the cruisel. A freeze on soviet SS-20s east of the Urals would also lend assurance to Japan, Rorea, and China, that their own security wasn't being sacrificed by an INF treaty.

The "walk in the woods" solution would have meant a major breakthrough in INE so long as both governments saw fit to pursue it. Unfortunately, it was rejected by both governments and instead became a major political propaganda issue. The unofficial agreement to the plan was subsequently denied by Rvitsinsky. According to him, Nitze's claim that the proposal was an "agreed-upon" deal, 
was aimed only to demonstrate some progress in the negotiations.9 Nitze, on the other hand, claimed that the proposal was based on Soviet willingness to drop the question of including British and french forces. According to Nitze, the soviets wanted to make it appear that all the initiative for the proposal came from Nitze alone, and then was rejected by the Reagan administration. Accordingly, the Soviets were attempting to show West European governments that breakdown in negotiations was the fault of U.S. inflexibility.10

Although the talks resumed in Geneva in the fall of 1982, continuing through 1983, nothing was accomplished. Both sides were adamant in their positions. Even where there was slight movement, the goals remained the same. It became clear that the Reagan administration was not willing to abandon any part of the scheduled deployment, whereas the Soviets were not about to sanction any deployment whatsoever. Following the death of Brezhnev, his successor, Yuri Andropov, merely reiterated the Soviet position. He offered to match British and French forces with reductions of Soviet medium-range missiles. The United States, however, would have to abandon its NATO deployments.11 The United States, for its part, arrived at what was known as the "Interim Solution." Until an understanding could be reached as to how to achieve a reduction to zero, the present balance must be redressed by moving ahead with 
new deployments. The actual number of missiles to be deployed, however, was claimed to be still negotiable.

In reality, this "solution" marked a major step away from the "dual track" decision which sought to preclude new missile deployments with arms control. Now, the administration was putting deployment ahead of any reductions. The "solution" also demonstrated the administration's expectations that the Soviets would continue negotiating once deployments began, or that a Soviet walkout would justify deployments. This zero-plus proposal, not surprisingly, was quickly rejected by the Soviet Union.

As the date for the delivery of the first Pershings drew nearer, negotiations reached a breaking point. The crisis over the downing of a South Korean airliner on 2 September 1983 merely added to the already frustrated relations between the two countries. On 28 september 1983 Andropov expressed Soviet frustration with the arms talks and the pointlessness of their continuation.12 On November 23rd, as the first Pershings arrived in West Germany, the Soviet delegation broke off negotiations. No date was set for their resumption.

\section{START}

The negotiations of START, like INF, were part of a U.S. solution to redress a perceived imbalance; in theater 
weapons, brought about by the buildup of soviet SS-20s during the 1970 s and, in strategic forces by the deployment of new Soviet ICBMs, in particular, the Ss-18, a tenwarhead, landbased, "monster MIRV." And, as in INF, both sides' positions stemmed from the same basic assumptions. According to prevailing U.S. policy, SALT II had sanctioned an imbalance in nuclear forces in favor of the soviet Union. The Soviet position, as stated by Gromyko, was that, "we proceed from the assumption that everything was balanced out in the SALT II treaty."13 Consequently, the goals of both sides in INF paralleled those in START. The United States sought deployment of new weapons systems in exchange for a reduction or limitation on existing soviet systems. The fate of START was linked to that of INF as well since the Soviet goal in START was to prevent new American deployments, strategic or theater. Indeed, the soviets had made it clear that a START treaty must be precluded by the cancellation of Pershing II and Tomahawk cruise missiles.

The long-awaited airing of Reagan's START proposal came on 9 May 1982 in a speech at Eureka College. ${ }^{14}$ Reagan spoke in vague, general terms about the proposal, the main essence of which was to achieve reductions in soviet missiles, most importantly the soviet "heavy" SS-18. The United states, for its part, would pursue a modernization of its own forces; the MX, B-1 and Stealth Bombers, cruise missiles, and Trident II. The Soviet Union was quick to 
reject the proposal, ired by the fact that Reagan was focusing limitations on Soviet land-based missiles, the backbone of their strategic forces. The United states, they claimed, had in effect agreed to leave those missiles alone at vladivostok in 1974. They also claimed that the United states was unwilling to sacrifice new weapons systems, such as the $\mathrm{MX}$, in exchange for soviet reductions.

Shortly after the Eureka speech, Brezhnev answered with his own proposal; a freeze on the production, testing, and deployment of both sides' strategic systems. This proposal would have not only frozen the quantity of the Soviet missiles that Reagan wanted reduced, but would have also blocked the United States from any further development of the stealth, MX, Trident II, and cruise missiles.

By autumn 1982 when START negotiators finally met in Geneva, both sides' positions were firmly set, and far apart. The Soviet team elaborated on Brezhnev's freeze proposal. They also reiterated Gromyko's warning in June 1982, that if the United States continued to pursue the issue of Soviet "heavies," the Soviet Union would be forced to reconsider the issue of American forward-based systems in Europe. ${ }^{13}$ Gromyko's warning was transformed into a proposal by the Soviet delegation in Geneva. Called the "reduction proposal," its main feature was a lower SALT II ceiling on total delivery vehicles (from 2250 to 1800 ) in exchange for a U.S. guarantee of no additional deployments of FBS. Thus, 
from the outset, START was inextricably linked with INF. The Soviets were making it perfectly clear that no progress in strategic arms reduction was possible as long as the United States proceeded with additional INF deployments. Also included in the "reduction proposal" was a new ban on all long-range cruise missiles. The SALT II Protocol, which had banned long-range sea and groundlaunched cruise missiles (SLCMs and GLCMs), but allowed airlaunched cruise missiles (ALCMs), had since expired. The United states was thus being asked to scrap its ALCM program.

Equally unacceptable to the Soviets was an American proposal designed specifically to reduce the number of Soviet "heavies," and the total number of land-based missiles in general. The proposal called for a two-phase reduction. The first phase limited the total number of ballistic warheads, with a subceiling on those based on land. The second phase established a low limit on ballistic throw-weight. Another U.S. proposal called for an "inventory limit" on undeveloped ICBMs. Whereas such a limit would deter only Soviet attempts to stockpile large numbers of extra ICBMs, it necessitated a verification arrangement to include on-site inspection of production and storage facilities, not to mention launch sites. The Soviets, though they agreed on the need for more stringent 
verification, were unwilling to accept such comprehensive verification measures.

By 1983 very little progress had been made in Geneva. The soviets remained adamant in their position against the scheduled deployment of new U.S. missiles in Europe, and against allowing new U.S. strategic programs to proceed at the expense of their present missile systems. Meanwhile, the Reagan administration was trying to steer a course of strategic buildup through domestic pressures for a nuclear freeze. ${ }^{16}$

In March 1983 Reagan approached the nation, and the Soviets, with a proposal to develop a new strategy and technology based on defense weapons systems, one that would, ". . give us the means of rendering. . nuclear weapons impotent and obsolete."17 Beside raising questions regarding the validity of strategic deterrence based on mutual assured destruction (MAD), the Strategic Defense Initiative (SDI) was immediately assailed by the soviet Union for perpetuating a new arms race and abandoning the 1972 ABM Treaty. ${ }^{18}$

In part, to assuage congress and the arms control lobby in Washington, and in order to avert cancellation of the MX, the Reagan administration in the fall of 1983, incorporated its "build-down" theory into START negotiations; a plan to retire older weapons at a faster pace than they are replaced.19 
With the additional proposal of "build-down" on the negotiating table, coupled with Reagan's newly proposed SDI program, the soviets were likely confused by the administration's arms control policy. Was the "build-down" supposed to replace the previous U.S. position in START? How would SDI affect START negotiations? To the Soviets, the "build-down" concept left the U.S. position in START as "vague, obscure, and unclear."20

The added confusion in START, however, seemed to matter very little by that time. START was already dead as the first Pershing IIs were delivered to West Germany. On 8 December 1983, two weeks after the INF talks were cancelled, the Soviets walked out of the strategic arms talks without a resumption date.

THE POLITICAL LEADER CHARACTERISTICS VARIABLE

The Reagan Administration

If hopes for the success of arms control as a viable foreign policy tool were diminished in late 1979 when President Carter withdrew the SALT II Treaty from further Senate consideration, those hopes were further dashed by the election of Ronald Reagan to the Presidency in 1980. All aspects of the new administration signaled an impending demotion of arms control in U.S. foreign policy and the promotion of an all-out effort to restore the military, and political superiority of a past era. 
In the military realm, this effort was based on the new administration's perspective that the nuclear balance had shifted decisively in favor of the Soviet Union. Blaming the "negotiability" of arms control, SALT in particular, Reagan embarked on a massive re-arming program.21 Such a program was also seen as the key to restoring political unity to NATO. Western Europe, as the new administration assumed, would regain the confidence in American leadership that it had lost during the Carter era.

\section{Personal Attitudes}

Within the domestic milieu of the Reagan administration, the factors which contributed most to an anti-arms control policy and, at least the initial success in support of that policy, can be accredited to Ronald Reagan himself, his strong conservative ideological views, the extent to which his decisions were based on ideology rather than thoughtful analysis, and his ability as a communicator.

Backed by a seasoned career in public speaking, as sportscaster, trade union activist, spokesman for General Electric, actor, and finally as Governor of California, Ronald Reagan took his conservative views on the campaign trail as a candidate with an "attractive personality and style as political performer." 22 Less government regulation of the free market, decentralization of federal government, 
lower taxes, and a tougher Soviet policy were the mainstay of his conservative platform.

Reagan's foreign policy was not surprising given his earlier record as a candidate for President. He campaigned against SALT and detente in 1976 on the premise that the Soviets were the only ones to benefit from it. During the 1980 campaign he came out in favor of a naval blockade of Cuba in order to force the Soviets out of Afghanistan. He also advocated the mining of Iranian ports in order to gain the release of U.S. hostages. Reagan's views, however, should not be seen as representing a casual approach to the use of force, as Barnet claims, as much as they should be seen as reflecting the attitudes of a man whose style and image was shaped by a "get tough" rhetoric, simplistic ideals, and superficiality.23

It appears that Ronald Reagan knew and cared little about strategy and concerned himself strictly with generalities. He was a speechmaker, not a policymaker. As Greenstein notes, Reagan's strong suit was dealing with general themes rather than the specifics of issues.

As a rhetorician who preferred anecdote to analysis he could be sold on policies or even political strategies without exploring their implications.24

\section{Participation}

In matters of arms control, Reagan displayed no realistic comprehension of the issues. His knowledge and 
participation merely reinforced the ideological extreme and simplicity of his world view. As Talbott notes, during prezero option NSC meetings, Reagan's attention would be lost as he began to doodle. "It was common.. . during long meetings on subjects about which he was less than passionate . . ."25

Examples of Reagan's participation in decisionmaking in arms control are numerous. Talbott reveals how, through long and highly technical debates over INF and START, Reagan formulated his own simplistic ideas.

Cruise missiles were 'good' because they were, by their nature, confined to retaliatory, second-strike missions; ballistic missiles were 'bad' because they were capable of preemptive, aggressive, first-strike missions. 26

The "walk in the woods" proposal, which allowed the Soviets to retain a lesser number of ballistic missiles. countered only by U.S. cruise missiles was, on the other hand, rejected by Reagan. In his mind, the United states would have to rely on "slow-flyers" (cruise missiles) in order to counter the soviet "fast-flyers" (SS-20s).27

In an interview with Time Magazine in october 1983 Reagan acknowledged that as recently as 1982 he did not realize that the bulk of soviet nuclear forces were made up of large land-based missiles. Nobody, he explained, had ever brought that up before. ${ }^{28}$ 
Scope of Authority

Aside from Reagan's personal attitudes, the initial success of his anti-arms control policy must also be accredited to a wide scope of authority. Reagan's election victory, which included ninety percent of the electoral vote (489 to 49 ), 29 the first Republican control of the senate since 1954, and a thirty-three seat Republican gain in the House, 30 provided Reagan with a perceived, if not real mandate for his policies.

Whether Reagan's conservative ideology was any indication of the popular attitude that voted him into office, it was his fine-tuned ability to communicate and influence, coupled with surrounding himself with other staunch conservatives, that ensured that his policies would prevail over more moderate voices from within both political parties. Although the Reagan administrative style could be called more of a cabinet government, given the President's reliance on his advisors for policy specifics and implementation, Reagan always reserved the final word on major issues for himself, which he then made public via emotional speeches or aggrandized press conferences. Though his decisions were often based on his own ideological outlook and simplistic views, his authority was generally undisputed. Whereas the same can hold true of any administration, it is a credit to Reagan's strong personality that advisors often were inclined to "tailor 
their recommendations to fit his presumed views and biases." 31

There is no question that the political leadership characteristics of the Reagan administration were a major contributor to the impasse in INF and START. From the outset, the U.S. position was one designed primarily to cast the image of serious negotiating while moving forward with the re-arming programs that Reagan had espoused. The basis of the zero option was more than an intentionally unacceptable proposal. It was part and parcel of the antisoviet, anti-communist ideology that characterized the Reagan administration. If the NATO "dual track" decision was partly designed to re-establish whatever momentum in arms control that SALT had once achieved, it most surely, too, became the ideal vehicle for the Reagan administration to achieve new missile deployments in Western Europe.

\section{Transition in Soviet Leadership}

Soviet behavior in INF and START was beset by internal problems, both economic and political. Expectations of improved economic performance were not realized. The national income annual growth rate was about 3 percent in 1982 as compared to over 9 percent in 1964.32 Industrial production fell from 7.3 percent in 1964 to 2.9 percent in 1982.33 In addition, poor agricultural harvests in 1979 and 1980, labor shortages, and increased competition for 
resource allocation between heavy and light industry put further demands on the leadership for reforms. Furthermore, the failure of Brezhnev's detente policy to expand trade and credit with the West, compounded the severity of the economic situation.

The failure of Brezhnev's economic and detente policies, the success of which was the mainstay of Brezhnev's leadership credibility, created a wider division among the top leadership over policy direction. As the Strodes note, the domestic coalition that had supported detente in 1970, dichotomized by "unilateralists" and "diplomatists," was now split by the failure of detente.34

That coalition was further weakened by the issue of leadership succession. Brezhnev's sustained poor health and increasing inability to perform in an official capacity prompted competition and political positioning within the Party ranks. The Soviet leadership, faced with the demanding problems of the economy and detente, was further detained from rebuilding any policy consensus by the ensuing struggle for succession. As the strodes concede, however, leaders vying for position,". . . may adopt positions for purely tactical reasons,"3s since the distinction between differing policy perspectives becomes "blurred" during periods of succession, the use of dichotomies in the analysis of Soviet politics may not be appropriate.36 
Soviet Policy in INF/START

Soviet policy during the early 1980s, therefore, may be considered a transitional period, marked by uncertainty, confusion, and an uncompromising, wait and see attitude in arms control. As Hedlin has observed, a climate of succession politics, marked by "contention" and "stalemate," is not conducive to new initiatives in soviet national security policy.37 Thus, he explains, this period of arms control was one of "meager accomplishment" during Brezhnev's last years, and of "continuity in substance and strategy" with Brezhnev's policies during Andropov's term as General Secretary.38

Whereas some observers of soviet politics may be more willing to credit Andropov with a new aggressiveness in foreign policy, citing, for example, his "peace offensive" in Western Europe, 39 events and actions indicate a growing reluctance by Brezhnev and Andropov to defend the priority of arms control as they had done in the 1970s. In an October 1982 speech Brezhnev made no mention of INF and START but called for top priority in military funding. 40 Speeches by other Politburo members also displayed a negative view toward arms control.41 Furthermore, although Andropov has been characterized as "pro-detente,"42 criticisms were voiced regarding the emphasis of cooperative diplomacy in soviet security policy.43

short of a complete reversal in policy, however, the 
tendency toward the "unilateralist" approach might be viewed more as a reassertion of the more traditional soviet view of peaceful coexistence, with its explicit call for continued conflict between socialism and capitalism. In this view, Soviet policy did not give way to the views of a competing faction, but was merely a reaffirmation of the long-term socialist goals adhered to by all Party leaders. Detente, not unlike peaceful coexistence, was meant to constrain the West, not the soviet Union. If it fails to do so, soviet socialism must prevail by other, unilateral means.

Soviet arms control proposals, the goals of which were to block NATO missile deployments and American strategic arms programs, were designed to retain the favorable correlation of forces achieved in the 1970s. But they also marked a change in the means to achieve these goals. Rather than constraining Western military buildup through treaty compromises and luring the West into a sense of relaxed tension, Andropov sought to unilaterally move ahead with his own military buildup while rhetorically influencing public opinion in the west with the idea that it was the United States that was not serious about arms control. Insofar as Soviet perceptions of the Reagan administration were correct, Soviet policy must also be seen as reacting to U.S. policy. The soviet walkout of INF in December 1983 demonstrated their frustration in negotiating with the Reagan administration. Beyond this, the walkout 
may also be seen as an indication that, within the top leadership, a reaffirmation of policy consensus had already emerged which in turn provided the political conditions allowing Andropov to drop arms control altogether.

Nevertheless, the succession issue, which remained at the forefront of Soviet politics due to Andropov's own declining health and lasting through the transitional period of Chernenko, sustained an unstable power arrangement in the Rremlin, thereby constraining whatever initiatives soviet leaders may have wished to advance.44

The fate of INF and START, therefore, was doomed as both the Soviet and American political leader characteristics proved unfavorable to arms control.

\section{THE SUBSYSTEM VARIABLES}

of any arms control regime thus far, perhaps INF/Start demonstrates the best case of subsystem influence on U.S. foreign policy. Arguments that hold the Reagan administration's confrontational and unilateral style of foreign policy responsible for the impasse in arms control negotiations are only valid to the extent that foreign policy failed to recognize and accommodate the constraints of the subsystem. The Reagan "challenge" to restore American power through military, political, and economic domination rather than accommodation went a long way in aggravating adversary and alliance relations alike. But it 
did not fundamentally alter them. On the contrary, it was Reagan's policies that were forced to adapt as his attempt to control the environment was challenged by recent changes within the subsystem itself. As Renneth Oye has keenly observed, "Ironically, the evolution of Reagan administration foreign policy may appear, in retrospect, as a textbook example of how the international environment shapes foreign policy."45

\section{Changed Security Perceptions}

The events and outcome of INF/START must therefore be linked to the transformation of the subsystem relationships. Relations between the United States and the Soviet Union reached a new low as the 1980 s began (see Appendix Table XV and Figure 2). The Soviet invasion of Afghanistan, the developing crisis in Poland, and new missile deployments, all but completely dismantled the detente established a decade earlier.

Relations between the United States and Western Europe also worsened as West European security concerns intensified (see Appendix Table XV). At one extreme allied fears were raised by a US/Soviet agreement (SALT II) which in their view had been made at the expense of European security. At the other extreme they feared the breakdown of detente and a return to cold war relations between the superpowers. 
The allies wanted reassurance from the United States that it would not allow the American nuclear deterrent to become decoupled from European deterrence. At the same time they sought reassurance from the United States that serious efforts to promote better East/West relations would not be lost to a renewed, sustained arms race. Alarmed by President Carter's about-face on his decision to provide allied countries with the neutron bomb, West European governments called upon the United States to deploy new missiles for NATO's deterrent. At the same time they called for new arms control negotiations as a way to promote a return to detente and hopefully to preclude new missile deployments.

This was the essence of the 1979 NATO Integrated Decision Document (IDD), otherwise known as the "dual track" decision. The deployment of Pershing II and cruise missiles was scheduled to begin in December 1983 unless arms control negotiations were successful in averting it.

Caught between the need to check the deployment of a new generation of soviet theater missiles (SS-20s) and the need to sustain an atmosphere of favorable East/West relations, West European governments walked a fine political line between detente and deterrence. Consequently, West European/Soviet relations in the latter 1970 s maintained a precariously balanced relationship as the US/Soviet detente 
faltered (see Appendix Tables X-XIII), then worsened as US/Soviet relations chilled during the early 1980s (see Appendix Table XIV).

Domestic pressures mounted as the fate of West European governments rested on the question of European security. Opposition parties in Britain, West Germany, Italy, and the intransigence of Belgium and the Netherlands, all scheduled to receive a share of the missile deployments, 46 threatened the survival of their pro-NATO governments. In order to strengthen themselves, and NATO, pressure had to be put on the United States and the Soviet Union to negotiate an agreement that reduced the risk of war in Europe.

\section{U.S. and Soviet Reaction}

In order to strengthen NATO unity it was necessary for the United states to focus on the needs of its allies. And, in order to divide the alliance, the Soviet Union would have to attempt to sway European public opinion, playing the Atlantic partners off one another by showing a willingness to negotiate. Consequently, the direction that US/Soviet relations would take, and that INF/START would follow, was largely dependent upon the political decisions of west European governments and the degree to which the two superpowers could elicit West European support for their own policy goals. To be sure, in INF/START Western Europe 
clearly had become a negotiating party without formal negotiating status. The "dual track" decision had set the scene for a situation in which the Europeans could more easily push the U.S. around--and the Soviet Union could more easily push the Europeans around. ${ }^{47}$

Having committed to the NATO dual track decision, the United States had made the deployment of a nuclear weapons program "dependent on prior allied consent" and a commitment to arms control a pre-condition to deployment. ${ }^{48}$ For President Reagan, with his antipathy toward arms control, the decision to back away from the 1979 decision would have been seen as a severe breach of faith between alliance partners, something for which he had criticized Jimmy Carter. It also would have given the Soviet Union, at no cost to them, a clear political victory over the west. For its own part, the United states would have to hold its allies to the deployment track while they, in turn, would have to hold the Reagan administration to arms control negotiations.

on the other hand, the "dual track" decision provided the Soviet Union with the unique opportunity to gain "a Soviet veto over any kind of deployment and the first step toward . . neutralization" of Western Europe. ${ }^{49}$ In the same vein, as Talbott asserts,

If the Soviets played the allies off against each other, fanned the hopes and fears of the West European peace movement, and exploited transatlantic tensions skillfully, they stood to win a double 
prize, a halt to a threatening military program, and new political discord within NATO.30

Both sides, therefore, were sufficiently motivated to participate in arms control negotiations, but not within the framework of SALT. The Reagan administration had been opposed to the treaty on the claim that it froze the nuclear balance in favor of the Soviet Union. The Soviets, too, had reason not to insist on a SALT framework. SALT II had been facilitated by agreeing not to include the American forwardbased systems as well as British and French systems. If the Soviets were to successfully block the deployment of Pershing II and cruise missiles, SALT II, for obvious reasons, could not be allowed to establish such a precedent for any new treaty.

The formal opening of INF negotiations did not take place until November 1981, one year after Reagan was elected President. The delay is certainly no surprise given the anti-arms control bias of his campaign. Reagan did, however, commit to arms control on the basis of the "dual track" decision in April 1981. Only after West European prodding and Soviet criticism did Reagan finally agree to begin discussions in Geneva.

The interim, though, was not wasted time as both sides began maneuvering for political position. Aimed both at building domestic support for defense programs and allied support for the scheduled missile deployments, Reagan sought 
to promote the soviet Union as the root of all evil in the world. He vowed that by regaining superiority the West would transcend and dismiss communism as a "sad, bizarre chapter in human history."si He renewed criticism of soviet troops in Afghanistan warning that any military action on their part against Poland would have "the gravest consequences." 22

The Soviet Union, in the meantime, launched an all out peace campaign directed primarily at western Europe in order to portray themselves as a peace-loving nation willing to compromise in the spirit of detente.33 In keeping with that line, Brezhnev initiated a proposal to begin discussions for reducing tensions between the superpowers.

\section{West European Reaction}

Alliance relations had further deteriorated by November. At a time when West European governments were trying to calm rising waves of public protest against higher defense spending and more nuclear weapons on their soil, the United states was pushing them to increase their individual contributions toward NATO defense. Secretary of Defense Weinberger told West Europeans, "The American people may not wish to bear the burden of necessary defense expenditures if they think some are doing less as we do more."54 During October and November demonstrations of over one million peace marchers gathered in West European capitals, including 
250,000 protesters in Bonn, 53 and 300,000 in Brussels.96 over three million marchers were expected to take part in planned demonstrations during "action week" in October.37

The European peace movement turned more anti-American than anti-Soviet, particularly following a remark by President Reagan that he "could see where you could have an exchange of tactical weapons against troops in the field without it bringing either one of the major powers to pushing the button."50 West Europeans were outraged by the President's admission of a contingency plan for limited nuclear war in Europe, but it seemed to attest to all their suspicions about Ronald Reagan. All the Soviet Union had to do was to sit back and empathize with European frustration. West European public opinion appeared to be on the Soviets' side.

\section{The Issue of Deployment}

From the beginning to end, INF/START was a forum, not for achieving real arms limitations or reductions, but for advancing political objectives. There were some within the Reagan administration who did not advocate earnest negotiations toward real arms reductions. But, it seems, to achieve real arms control in the early 1980 s was, at best, wishful thinking. Spurgeon Keeny, who was deputy director at the Arms Control and Disarmament Agency (ACDA) at the time of the "dual track" decision, admits that the 
commitment to arms control was solely to promote new missile deployments rather than real missile reductions:

most people. . looked on this as a political necessity to get NATO acceptance of the deployment, rather than something where the arms control process had a serious chance of success.99

Deployment was the real issue. Since neither the Pershing II nor the cruise missile would be ready for deployment until December 1983, INF/START would be guaranteed a life span of at least two years, unless of course the United states were to renege on its commitment to deployment, or the Soviet Union either gave up its attempt to prevent deployment or agreed to reduce the number of its ss-20s. The soviets, though, had little incentive to concede their position since they had two years in which to persuade West Europeans that deployment was not in their best interests. The soviets also were quite aware, as Talbott explains, that the longer they "could get the west Europeans to procrastinate, the less bargaining leverage the U.S. would have in the negotiations." 60

The next chapter in arms control promised to be little more than an exchange of proposals, based not on their negotiability, but intended for West European consumption. While American negotiators hammered out the virtues of the "zero option," their Soviet counterparts espoused Brezhnev's moratorium on further deployments pending a treaty. In addition, they presented their own version of "zero" which 
meant establishing Europe as a nuclear free zone. If total zero was unacceptable to the United States, then, the Soviets suggested, a four point plan designed to achieve reductions in medium-range systems after a moratorium was in effect, followed by the eventual elimination of all nuclear weapons from Europe.

In order to promote his proposals and timed to take advantage of public demonstrations, Brezhnev personally travelled to Bonn in November 1981. There he offered to take the first step by unilaterally eliminating hundreds of Soviet missiles.61 The missiles he spoke of, however, were the older ss-4s and ss-5s which the ss-20s were to replace anyway. Nevertheless, Brezhnev's proposal struck a popular note among West Europeans. And, although West European governments continued to stand by the deployment decision, the Soviet peace campaign made it difficult for allied governments to maintain a consensus in favor of deployment.

\section{Alliance Relations}

The more West European governments were pressured, the more that pressure was re-directed at the United States to break the arms control impasse and find some formula for compromise. Such was the political backdrop leading to the "walk in the woods" solution. The significance of this initiative was that, where it might have been used to dispel West European concerns that no progress was being made 
toward an agreement, in fact it was not. Both sides rejected the plan. The United States even wanted to withhold the fact that a Nitze-Kvitsinsky arrangement ever took place. The Reagan administration feared that allied consultation and the possibility of allied approval might force the United states to adopt the plan as a basis for agreement.

European suspicions were renewed that any attempt at progress in arms control by the United States was taking a back seat to nothing less than full deployment of the 572 Pershing and cruise missiles. What should have been clear, and perhaps it was, was that the U.S. commitment to deployment, based on the alliance call for stronger NATO leadership and solidarity, as defined by the 1979 NATO decision, would essentially prevent any serious arms agreement from being achieved. This was also evident in one of the administration's main arguments against a nuclear freeze.

A freeze would cast serious doubt on American leadership of the NATO alliance. . . A freeze now, would, in effect, be a unilateral decision by the United states to withdraw from this joint allied undertaking. 62

A continuation of arms control dialogue between the United States and the Soviet Union, however, was also a necessary part of that commitment to alliance solidarity, at least until those governments, designated as recipients of deployment, formally accepted the new missiles. The Soviet 
Union, meanwhile, took the opportunity to woo Western Europe away from deployment as strained alliance relations were further tested.

Anti-nuclear demonstrations continued in Europe. The nuclear freeze movement in the United States gained legislative sponsorship in Congress. Secretary of state Alexander Haig resigned.63 Arguments were renewed advocating a no first-use nuclear strategy for NATO.64 By 1981 US/West European relations were at the lowest point in ten years (see Figure 2). Serious damage to alliance relations occurred in 1982 as the result of a controversy involving East/West trade policy.65 The United States was concerned that a decision by Britain, France, West Germany, and Italy to sell equipment to the Soviet Union for the construction of a pipeline to be used to supply gas to Western Europe would dangerously increase their dependency on the Soviet Union.

The allies did not share this view. Only a small fraction of their total energy needs would be provided by the pipeline. The crisis developed, however, when the United states decided to invoke sanctions against American companies and their European subsidiaries involved in the pipeline deal. The allies saw this action as an infringement on their sovereignty and refused to reverse their decision. In order to prevent any permanent rift in 
the alliance, the Reagan administration was forced to call off the sanctions only a few months later.

The significance of the pipeline controversy was much more than a crisis in alliance solidarity. It underscored the basic differences between American and West European security policy. The United States sought to deter Soviet aggression by isolating the Soviet Union. The Europeans argued for greater economic interdependence between East and West. The carrot and the stick approach to soviet policy divided alliance perceptions of security. Western Europe pressed the need for arms control while the United States pressed for deployment.

Soviet Policy: Last Chance to Divide NATO on Deployment

The Rremlin's strategy was to exploit these differences. Threats were made to walk out of arms control negotiations and to deploy new nuclear weapons if the NATO deployment proceeded. In December 1982 Yuri Andropov offered to reduce the number of medium-range missiles to match those of the British and French forces.65 In January 1983 the Soviets offered to negotiate a non-aggression pact with NATO.

As the 1983 deployment date drew nearer it became more doubtful that the Soviets would be able to prevent or even delay deployment. The upcoming west German elections in March 1983 presented a last chance opportunity to turn the 
tide against deployment. If West German public opinion could be swayed enough in opposition, then perhaps Helmut Rohl's government would have to rely on a coalition more committed to arms control, or to some concessions on deployment.

Rohl's party was victorious, and in the aftermath of the election the United States did propose the "interim solution" that qualified only partial deployment until an agreement could be reached on a reduction to zero. This "zero plus" proposal was presented primarily to bolster Kohl's new government, while preparing the way for the arrival of the first shipment of Pershing IIs in west Germany. 67

By fall 1983 the Soviets were dropping strong hints of discontinuing INF negotiations.68 The september Korean airliner incident seriously damaged western perceptions of peaceful Soviet intentions. ${ }^{69}$ Alliance relations experienced a leveling off of tension in 1983 (see Figure 2). As the first cruise missiles arrived in Britain in December 1983, the Soviets walked out of INF and START negotiations.

\section{CONCLUSION}

By 1980 US/Soviet relations had reached the lowest level of cooperation thus far (see Figure 2). From a bilateral perspective, US/Soviet arms control negotiations 
had very little chance of convening, let alone succeeding with an arms control treaty.

The analysis of the Reagan administration concludes a definite anti-arms control posture. The analysis of the transition and confusion in Soviet politics supports the conclusion of minimal motivation for arms control

negotiations. Since the two superpowers did enter into arms control negotiations, the motivation can only be understood by adding the subsystem perspective.

The trilateral political environment of INF/START had been established by 1979. It had been decided that cruise and Pershing II missiles would be deployed in western Europe, but would be coupled with arms control efforts. NATO's "dual track" decision and the zero-option position of the United states were not so much bargaining chip and leveraging tactics to gain soviet concessions as they were reflections of NATO ambivalence in Western security policy. In this view, the "dual track" decision was at once designed to calm West European fears of entrapment (in an atmosphere of growing perceptions of US/Soviet confrontation), and to allay West European fears of abandonment (in response to West European perceptions of an increasing Soviet military threat).

INF/START was, therefore, a forum in which U.S. and Soviet arms control policy was largely set and played out according to two relationships; US/West European and West 
European/Soviet. INF and START negotiations thus proceeded on the basis of U.S. policies that sought to promote alliance unity and soviet policies that sought to promote alliance disunity.

US/West European relations did level off with American reassurance that deployment would proceed, but the degree of unity remained low as negotiations stagnated toward a treaty that could preclude the deployment of cruise and Pershing IIs (see Figure 2). West European/Soviet relations bettered somewhat by 1983 (see Figure 2) due to some success by the Soviet Union to opportunize on West European entrapment concerns.

The motivation to negotiate INF/START, however, was lost as the deployment half of the "dual track" decision became a reality. The soviets cancelled all arms talks in December 1983 and US/Soviet relations took a sharp turn downward (see Figure 2). US/Soviet relations and US/Soviet arms control were, therefore, most significantly the result of the subsystem environment in which the assumed behavior of the alliance/adversary model were played out. 


\section{CHAPTER IV NOTES}

1 For an informative discussion on the rationale for this decision and how the decision was reached see, stephen R. Hanmer, Jr., "NATO's Long-range Theatre Nuclear forces: Modernization in Parallel with Arms Control," NATO Review (vol. 28, February 1980).

2 The Integrated Defense Document (IDD) came about rather interestingly. The High Level Group, made up primarily of defense ministers, would handle the planning of new missile deployments for Europe. Concerned that the "dual track" concept might be compromised and monopolized by the bias toward deployment, the special consultative Group was formed, primarily of foreign ministers, with its purpose to promote the arms control track and perhaps render deployment unnecessary. The combined result of the two groups' reports, as contradictory as they were, became the basis for the 1979 NATO "dual track" decision.

${ }^{3}$ Strobe Talbott, Deadly Gambits (New York: Alfred A. Knopf, Inc., 1984), p. 45 .

${ }^{4}$ Ibid., p. 72 .

Ibid., p. 79 .

'See, Gerhard Wettig, "The soviet INF Data Critically Reviewed," Aussen Politik (Vol. 34, No. 1, January 1983).

7 See, for example, "Soviet Subs Move into Atlantic," The Oregonian (January 28, 1984), p. A9; and, "New Soviet Missile Reported," The Oregonian (March 1, 1984), p. A10.

${ }^{8}$ For some thoughts on Nitze's motivations, see, Talbott, Deadly Gambits, p. 118 .

"Yuli Rvitsinsky, "Soviet View of Geneva," The New York Times (January 12, 1984), p. A31.

10 Paul H. Nitze, "The U.S. Negotiator's View of the Geneva Talks," The New York Times (January 19, 1984), p. A23.

11 Erom a speech by Andropov, December 21, 1982, cited in Talbott, Deadly Gambits, p. 161.

12 See, Andropov's speech, cited in its entirety, Strobe Talbott, The Russians and Reagan (New York: Vintage Books, 1984), pp. 119-127. 
13 Speech by Andrei Gromyko at the United Nations, June 1982, cited in Talbott, The Russians and Reagan, p. 60 .

14 Talbott, Deadly Gambits, p. 263.

${ }^{15}$ Ibid., p. 279.

16 By April 1982, the Rennedy-Hatfield resolution introduced in Congress March 10, 1982, had the support of 166 members of the House of Representatives and 24 members of the United States Senate. In addition, the nuclear freeze movement in the United States gained wide grassroots support across the country with hundreds of organizations, city councils, and state legislatures passing similar resolutions.

See, Senator Edward M. Rennedy and Senator Mark 0 . Hatfield, Freeze: How You Can Help Prevent Nuclear War (New York: Bantam Books, 1982).

17Michael Reese, et al., "Rethinking the Unthinkable," Newsweek (April 4, 1983), p. 16.

18 Ibid., p. 16.

${ }^{19}$ For an excellent discussion of the "build-down" concept see, Alton Frye, "Strategic Build-Down," Foreign Affairs (Winter, 1983-84).

${ }^{20}$ Talbott, Deadly Gambits, p. 340 .

21 Talbott, Deadly Gambits, pp. 6-7. By negotiability Reagan had in mind the need to either build up to match the Soviets or the Soviets build down to match the United states.

22 Fred I. Greenstein, ed., The Reagan Presidency: An Early Assessment (Baltimore, John Hopkins University Press, 1983), p. 5 .

${ }^{23}$ Richard Barnet, The Alliance (New York: Simon and Schuster, 1983), p. 410 .

24 Greenstein, The Reagan Presidency: An Early Assessment, p. 11 .

2 Talbott, Deadly Gambits, pp. 249-250.

${ }^{26}$ Ibid. , p. 132 .

27 Ibid. , p. 132 .

28 Ibid., p. $263 n$. 
29 Statistical Abstract of the United States 1988 ,

"Vote Cast for President," (Washington D.C.: U.S. Bureau of the Census, 1988), p. 232 .

${ }^{30}$ Ibid., "Composition of Congress," p. 242.

31 Alexander Dallin and Gail w. Lapidus, "Reagan and the Russians: United States Policy Toward the Soviet Union and Eastern Europe," in Renneth A. Oye, et al, eds., Eagle Defiant: United States Foreign Policy in the 1980s (Boston: Little, Brown and Company, 1983), p. 202 .

32 Boris Rumer, "Structural Imbalance in the Soviet Economy," Problems of Communism (July-August 1984).

${ }^{33}$ Ibid. , p. 24.

${ }^{34}$ Dan L. Strode and Rebecca V. Strode, "Diplomacy and Defense in Soviet National Security Policy," International Security (Vol. 8, No. 2, Fall 1983).

${ }^{35}$ Ibid., p. 112 .

${ }^{36}$ Ibid. , p. 112 .

37Myron Hedlin, "Moscow's Line on Arms Control," Problems of Communism (May-June 1984), p. 19.

3aIbid., p. 19.

39 Zhores A. Medvedev, Andropov (New York: W.W. Norton and Co., Inc., 1983), pp. 186-194.

40 Strode and Strode, "Diplomacy and Defense in Soviet National Security Policy," p. 109.

41 Ibid., p. 103.

42 See, for instance, Jerry F. Hough, "Soviet Succession: Issues and Personalities," Problems of Communism (September-october 1982).

${ }^{43}$ Strode and Strode, "Diplomacy and Defense in Soviet National Security Policy," pp. 114-115.

${ }^{44}$ This description of an unstable power arrangement comes from, Marc D. Zlotnik, "Chernenko Succeeds," Problems of Communism (March-April 1984).

${ }^{45}$ Kenneth A. Oye, "International systems structure and American Foreign Policy," in, Oye, et al., Eagle Defiant, p. 31 . 
${ }^{46}$ The proposed deployment of new U.S. missiles in western Europe included 108 Pershing IIs and 464 cruise missiles. West Germany would get all 108 Pershing IIs plus 96 cruise missiles, Britain would get 160 cruise missiles, Italy 112 cruise missiles, Belgium and the Netherlands 48 cruise missiles each.

47 Talbott, Deadly Gambits, p. 51.

${ }^{48}$ Christoph Bertram, "The Implications of Theater Nuclear Weapons in Europe, Foreign Affairs (Vol. 60, Winter 1981-1982), p. 310 .

49 Henry Rissinger, as quoted in Russell Watson, et al., "Battle over Missiles," Newsweek (October 24, 1983), p. 37 .

50 Talbott, Deadly Gambits, p. 39.

51 From Reagan's speech at Notre Dame University, "Excerpts from the President's Address," The New York Times (May 18, 1981), p. B7.

52 Bernard Gwertzman, "Warsaw Pact Games Arouse U.S. Concern, a Warning is Issued," The New York Times (March 6, 1981), p. A1, A4.

${ }^{3} \mathrm{~A} .0$. Salzberger, Jr., "Soviet Embarks on Blitz in U.S. of News Media," The New York Times (March 13, 1981), p. A7.

${ }^{5}$ Caspar Weinberger, as quoted in Barnet, The Alliance, p. 428 .

55250,000 at Bonn Rally Assail U.S. Arms Policy," The New York Times (October 11, 1981), p. 1 .

36 "350,000 in Amsterdam Protest A-Arms," The New York Times (November 22, 1981), p. 3 .

${ }^{57}$ Russell watson, et al., "Battle over Missiles," p. 36 .

${ }^{50}$ From a question and answer session at the white House with visiting editors. Quoted in, Bernard Gwertzman, "President Says U.S. Should Not Waver in Backing Saudis," The New York Times (October 18, 1981), p. 1, 15.

59R. Jeffrey Smith, "Missile Talks Doomed from the Start," Science, (February 10, 1984, Part 2 of 4), p. 566.

60 Talbott, Deadly Gambits, p. 91. 
61 Ibid., p. 90.

62 The Nuclear Freeze (Publication of the Department of State, April 1982), p. 6.

${ }^{63}$ Secretary Haig was considered by many West Europeans as their closest ally in the Reagan administration. Haig, who had held the position of NATO Commander, was often charged by his colleagues with being too solicitous of the Europeans.

${ }^{64}$ MCGeorge Bundy, George F. Kennan, Robert S. McNamara, and Gerard Smith, "Nuclear Weapons and the Atlantic Alliance," Foreign Policy (Vol. 60, No. 4, Spring 1982 ).

${ }^{65}$ The rift in trade policy was a result of Western reactions to a crisis in poland. Following a military coup in Poland in December 1981, the United States implemented a series of embargoes and sanctions on the export of energyrelated technology to the Soviet Union, seriously jeopardizing a joint West European/Soviet pipeline project to supply Western Europe with natural gas.

${ }^{66}$ Andropov's proposal, December 1982, cited in Talbott, Deadly Gambits, p. 161 .

67For a detailed discussion of the "interim solution" see, Talbott, Deadly Gambits, pp. 171-184.

68 See, for example, Andropov's statement, December 28, 1983, cited in Talbott, The Russians and Reagan, pp. 119127; and, Anatoly Dobrynin's statement about the "nearinevitability of suspension" of INF and START, cited in, Talbott, Deadly Gambits, p. 196.

$6{ }^{9}$ George $J$. Church, "Turning on the Heat," Time (September 19, 1983), pp. 12-16. 
CHAPTER V

CONCLUSION

\section{RESEARCH SUMMARY}

By examining West European/US subsystem variables, in addition to domestic and bilateral processes, this study has demonstrated that US/Soviet arms control, including the motivation to negotiate, negotiating positions and the result of negotiations, is significantly affected by these subsystem relationships and is not entirely the outcome of a bilateral process involving only domestic political factors. Based on this study's analyses of SALT I, SALT II, and INF/START, the trilateral relationship of the United States, the Soviet Union, and Western Europe has had a definite impact on US/Soviet arms control.

This study has also demonstrated that the behavior of the United States and the Soviet Union toward arms control (acting in accordance with the alliance/adversary model) has been consistently associated with changes in West European security perceptions and U.S. and Soviet reactions to those changes. Changes in these relationships have been largely responsible for determining the political environment in 
which the fate of US/Soviet arms control has been played out. It is likely they will do so in the future.

\section{POLICY IMPLICATIONS}

This study points up several policy considerations necessary in understanding current arms control negotiations.

First, policymakers must consider the idea that subsystem influence on arms control may remain constant while domestic political factors in U.S. and Soviet foreign policymaking may vary. As long as the behavior of each actor toward the other remains consistent with their role as alliance partner and/or adversary, changes in U.S. and Soviet domestic political factors, such as the Political Leader Characteristics Variable used in this study, cannot entirely determine the fate of US/Soviet arms control. Policymakers must not only recognize the existence of subsystem influence (i.e., West European concerns of abandonment or entrapment), they must also consider the political implications of attempting to control that influence. This may be done either by continuing to manage the existing subsystem relationships, or by changing or eliminating the central features of those relationships-those of military alliance partners and adversaries.

As evidenced in this study, the management of alliance relations has often hindered US/Soviet arms control by 
creating new security concerns. United states reaction to West European entrapment or abandonment concerns has generally created further changes in west European security perceptions, and subsequently, renewed U.S. reaction. such a "circular" pattern of relations does not seem conducive to creating a more consistent positive environment for arms control. The right questions regarding more favorable and stable conditions for arms control, therefore, may well be ones which take to issue the nature of alliance relations, including the dissolution of NATO.1 As Sharp has argued, simply adjusting defense policies as part of alliance management will likely lead to west European perceptions of abandonment or entrapment, or both, "thereby becoming part of the problem rather than the solution."

This dilemma of alliance management is also evidenced in more recent arms control negotiations. The Reykjavik summit meeting in october 1986, produced great concerns of abandonment in Western Europe as Reagan and Gorbachev spoke of eliminating all nuclear weapons in Europe. ${ }^{3}$ The signing of the INF Treaty in December 1987 raised questions regarding both entrapment (greater risk of conventional war in Europe), and abandonment (a move toward European denuclearization and American disengagement).4 Indeed, the dilemma involving INF and alliance cohesion was responded to with calls for modernizing conventional weapons in Europe, ${ }^{3}$ conventional and short-range nuclear weapons negotiations, 
and calls for Western Europe to take greater responsibility for its defense. 6

A second consideration for present arms control policymaking concerns keeping soviet foreign policy in historical perspective. Similar to Brezhnev's detente policy in SALT I, the success of Gorbachev's domestic policies of perestroika and glasnost are linked to East/West cooperation and a policy of dividing NATO politically rather than militarily. A trend toward an atmosphere of neodetente, coupled with a "tendency in the west to equate arms control with peace," helps strengthen Gorbachev's domestic position as well as relaxing alliance purpose. U.S. policymakers must be cautious of Gorbachev's motives as well as sensitive to West European concerns. West European budgetary concerns and the problem for West European governments in maintaining fragile coalitions with opposition parties require Western Europe to adopt better relations with the Soviet Union.

Grand proposals in arms control, such as Gorbachev's recent offers to unilaterally reduce the soviet military by 500,000 men and 10,000 tanks over the next two years, ${ }^{8}$ and the removal of nuclear missiles and other arms under the control of 50,000 troops to be pulled out of Eastern Europe, ${ }^{9}$ must be viewed suspiciously as renewed efforts toward the political intimidation of Western Europe. Once again, alliance relations may be tested as the United states 
faces the issues of allowing closer West European/Soviet ties, negotiating further arms control, and shoring up alliance cohesion with arms modernization.

\section{FUTURE ARMS CONTROL NEGOTIATIONS}

This year marks a new chapter in arms control. INF is behind us now, and the success of START and the conventional Armed Forces in Europe (CAFE) negotiations will be influenced by the same variables that have affected past arms control negotiations. The Bush administration is faced with problems at home such as drugs, crime, the homeless, and the national debt. The theme of bipartisanship will be a key factor in determining policy goals and priorities.10 Arms control will play a central role in this domestic political atmosphere as the realities of "executivecongressional engagement" are played out.

Gorbachev will likely deal with Bush from a stronger domestic position, though he may come under greater internal pressure to show positive results from his reforms. Unlike Brezhnev, however, Gorbachev's reforms have been radical and far reaching, and their effects may take several years to filter through the system. The soviet withdrawal from Afghanistan, and proposals to cut back the military, combined with the effects of internal restructuring and a more open society, will surely test Soviet power at home and abroad. If Soviet reforms are the reaction to the USSR in 
decline, 11 then Gorbachev may likely continue the current trend in policies. The West must be aware, however, that based on past actions, Soviet policies of cooperation can be deceiving.

Another consideration for arms control policymaking is that Western Europe will likely continue to become a more influential political and economic power. Further steps will likely be made toward West European integration.12 Western Europe will have greater influence on questions regarding its own security. US/Soviet arms control negotiations involving conventional weapons in Europe will involve a more direct decisionmaking responsibility for west European governments. The military capabilities of European NATO nations will not be as easily ignored as they were in SALT and INF.

If the central features of the subsystem relationships are left unchanged, what we may likely see is a continuation of the cyclical pattern of relations that has governed arms control thus far. If this is the case, then we are entering a positive environment for arms control. Western Europe and the Soviet Union need closer ties with one another for political as well as economical reasons. Closer West European/Soviet relations will rely on continued US/Soviet cooperation.

If, however, the central features of the subsystem relationships are changed, due to either the dissolution of 
NATO as we now know it, or the end of the Us/Soviet adversarial relationship, the 40 th anniversary of NATO may mark the end of an era, and the beginning of a totally new arms control environment. 
CHAPTER V NOTES

This policy implication has recently been touched upon, although not specifically as a response to the issue of subsystem influence on arms control. Several examples of pro-alliance management can be found. See, for example, Michael R. Gordon, "INE: A Hollow Victory?" Foreign Policy (No. 68, Fall 1987), and; Jonathan Dean, "Military Security in Europe," Foreign Affairs (Vol. 66, No. 1, Fall 1987).

For a pro-disengagement argument, see, for example, Christopher Layne, "Atlanticism without NATO," Foreign Policy (No. 67, Summer 1987).

2Jane M.O. Sharp, "Arms Control and Alliance Commitments," Political Science Quarterly (Vol. 100, No. 4,

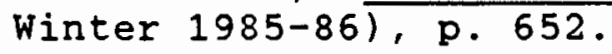

3 Two noteworthy discussions of the Reykjavik summit include, Michael Mandelbaum and strobe Talbott, "Reykjavik and Beyond," Foreign Affairs (Vol. 65, No. 2, Winter 198687), and; James Schlesinger, "Reykjavik and Revelations: A Turn of the Tide?" Foreign Affairs (Vol. 65, No. 3, 1986).

${ }^{4}$ For a detailed discussion of West European reaction to INF, see, for example, Lynn E. Davis, "Lessons of the INF Treaty," Foreign Affairs (Vol. 66, No. 4, Spring 1988).

5ee, for example, Jeffrey Record and David B. Rivkin, Jr., "Defending Post-INF Europe," Foreign Affairs (Vol. 66, No. 4, Spring 1988), and, more recently; Melissa Healy, "NATO Chief Offers Modernization Plan," The Oregonian (August 11, 1988), p. A11.

"Bryan Brumley, "U.S. prods NATO allies to do more," The Oregonian (December 29, 1988), p. A9.

${ }^{7}$ Dimitri K. Simes, "Gorbachev: A New Foreign Policy?" Foreign Affairs (Vol. 65, No. 3, 1986), p. 492 .

Bill Reller, "Soviet tells U.N. he will make "unilateral' troop reductions," The oregonian (December 8 , 1988), pp. A1, A14.

${ }^{9}$ Carol J. Williams, "When soviet troops leave, so will their nuclear arms," The Oregonian (January 20, 1989), p. A5.

10 The theme of bipartisanship was part of George Bush's inaugural speech. "And we need a new engagement, too, between the executive and the congress... A new breeze is blowing--and the old bipartisanship must be made 
new again." Excerpts are from transcripts re-printed in The Oregonian (January 21, 1989), p. A15.

The theme was also promoted in Henry Kissinger and Cyrus Vance, "Bipartisan Objectives for Foreign Policy," Foreign Affairs (Vol. 66, No. 5, Summer 1988).

11 Robert G. Kaiser, "The U.S.S.R. in Decline," Foreign Affairs (Vol. 67, No. 2, Winter 1988-89), p. 97 .

12 Such efforts may include progress in the development of an Anglo-French nuclear weapons system, formation of a Franco-German military brigade; or have included, the revival of the Western European Union (WEU), and the formation of the Franco-German Council on Defense and security. 


\section{SOURCES CONSULTED}

Books

Allen, Gary. Richard Nixon: The Man Behind the Mask. Belmont, Mass.: Western Islands, 1971.

American Security Council Foundation. A strategy for Peace through strength. Boston, Mass.: The American Security Council Foundation, 1984.

Barber, James David. The Presidential Character. Englewood Cliffs, N.J.: Prentice-Hall, 1972 .

Barnet, Richard J. The Alliance. New York: Simon and Schuster, 1983 .

Beer, Francis A. Integration and Disintegration in NATO. Ohio state University Press, 1969.

Bloomfield, Lincoln P. The Foreign Policy Process. Englewood Cliffs, N.J.: Prentice-Hall, 1982 .

Breslauer, George W. Krushchev and Brezhnev as Leaders: Building Authority in Soviet Politics. London: George Allen and Unwin, Ltd., 1982.

Brodie, Fawn M. Richard Nixon: The Shaping of His Character. New York: W.W. Norton and Co., 1981.

Caldwell, Lawrence T. Soviet Attitudes to SALT. Adelphi Papers No. 75. London: Institute of Strategic Studies, 1971.

Carter, Jimmy. Reeping Faith. New York: Bantam Books, 1982 .

Dougherty, James E., and Pfaltzgraff, Robert L., Jr. Contending Theories of International Relations. New York: Harper and Row, Publishers, Inc., 1981.

East, Maurice A.; Salmore, Stephen A.; and Hermann, Charles F., eds. Why Nations Act. Beverly Hills: Sage Publications, 1978.

Edwards, David V. Arms Control in International Politics. New York: Holt, Rinehart and Winston, 1969. 
Evans, Rowland, and Novak, Robert. The Reagan Revolution. New York: E.P. Dutton Publishing Co., Inc., 1981.

Ford, Gerald R. A Time to Heal. New York: Harper and Row, Publishers, Inc., 1979.

Greenstein, Fred I., ed. The Reagan Presidency: An Early Assessment. Baltimore: Johns Hopkins University Press, 1983.

Hough, Jerry F., and Fainsod, Merle. How the Soviet Union is Governed. Cambridge, Mass.: Harvard University Press, 1980.

Jordan, Hamilton. Crisis: The Last Year of the Carter Presidency. New York: G.P. Putnam's Sons, 1982 .

Kaplan, Morton A., ed. SALT: Problems and Prospects. Morristown, N.J.: General Learning Press, 1973.

- System and Process in International Politics. New York: Robert E. Krieger Publishing Co., 1975.

Kennedy, Edward M., and Hatfield, Mark O. Freeze! How You Can Help Prevent Nuclear War. New York: Bantam Books, 1982 .

Kintner, William R., and Pfaltzgraff, Robert L., Jr., eds. SALT: Implications for Arms Control in the 1970s. Pittsburgh: University of Pittsburgh Press, 1973.

Rissinger, Henry A. For the Record: Selected statements 1977-1980. Boston: Little, Brown and Co., 1981.

The White House Years. Boston: Little, Brown and Co., 1979 .

Kolkowicz, Roman. The Red Hawks on the Rationality of Nuclear War. Santa Monica: Rand Corp. RM-4899, 1966.

Kolkowicz, Roman, et al. The Soviet Union and Arms Control: A Superpower Dilemma. Baltimore: The Johns Hopkins Press, 1970 .

Labrie, Roger P., ed. SALT Handbook: Key Documents and Issues 1972-1979. Washington D.C.: American Enterprise Institute for Public Policy Research, 1979.

Lenczowski, John. Soviet Perceptions of U.S. Foreign Policy. Ithaca: Cornell University Press, Ltd., 1982. 
Liska, George. Nations in Alliance. Baltimore: Johns Hopkins University Press, 1962.

Litwak, Robert $S$. Detente and the Nixon Doctrine. London: Cambridge University Press, 1984.

Mazlish, Bruce. In Search of Nixon: A Psychohistorical Inguiry. New York: Basic Books, Inc., 1972.

McClelland, Charles A., et al. The Communist Chinese Performance in Crisis and Noncrisis: Quantitative Studies of the Taiwan straits Confrontation, 19501964. China Lake, Ca.: U.S. Naval Ordnance Test Station, 1967.

Medvedev, Zhores. Andropov. New York: W.W. Norton and Co., Inc., 1983. 1986 .

The NATO Handbook. Paris: NATO Information Services, 1983.

Newhouse, John. Cold Dawn: The Story of SALT. New York: Holt, Rinehart and Winston, 1973.

Nixon, Richard. The Real War. New York: Warner Books, Inc., 1980.

Osgood, Robert. NATO: The Entangling Alliance. Chicago: University of Chicago Press, 1962.

Oye, Kenneth A.; Lieber, Robert J.; and Rothchild, Donald, eds. Eagle Defiant: United States Foreign Policy in the 1980s. Boston: Little, Brown and Co., 1983.

Plano, Jack C., and Olton, Roy, eds. The International Relations Dictionary. Third edition. Santa Barbara, Ca.: ABC-CLIO, 1982 .

Schwartz, Morton. Soviet Perceptions of the United States. Berkeley: University of California Press, 1978.

Shevchenko, Arkady N. Breaking with Moscow. New York: Ballantine Books, 1985 .

Shoup, Laurence $H$. The Carter Presidency and Beyond: Power and Politics in the 1980s. Palo Alto, Ca.: Ramparts Press, 1980. 
Smith, Gerard. Doubletalk: The Story of the First strategic Arms Limitations Talks. Garden City, N.Y.: Doubleday, 1980 .

Smith, Hendrick, et al. Reagan the Man, the President. New York: Macmillan, 1980.

Statistical Abstract of the United States 1982-83. 103rd edition. Washington D.C.: U.S. Bureau of the Census, 1982 .

Talbott, Strobe. Deadly Gambits. New York: Alfred A. Knopf, 1984.

- Endgame: The Inside Story of SALT II. New York: Harper and Row, 1979.

The Russians and Reagan. New York: Random House, Inc., 1984 .

terHorst, Jerald F. Gerald Ford and the Future of the Presidency. New York: The Third Press, 1974.

Ulam, Adam B. Expansion and Coexistence: Soviet Foreign Policy 1917-73. New York: Praeger Publishers, 1974 .

Van der Linden, Frank. The Real Reagan. New York: William Morrow and Co., Inc., 1981.

Vance, Cyrus. Hard Choices. New York: Simon and Schuster. 1983.

Waltz, Kenneth N. Theory of International Politics. Menlo Park, Ca.: Addison-Wesley Publishing Co., 1979.

Weeks, Albert. The Troubled Detente. New York: New York University Press, 1976.

Journals, Magazines, Newspapers, Other Publications

"250,000 at Bonn Rally Assail U.S. Arms Policy." New York Times. 11 October 1981, p. 1 .

"350,000 in Amsterdam Protest A-Arms." New York Times.

22 November 1981 , p. 3.

Alexiev, Alex R. "The Soviet Campaign against INF: Strategy Tactics, and Means." ORBIS. Vol. 29, No. 2 (Summer 1985): pp. 319-350. 
Aspaturian, Vernon. "The Soviet Military-Industrial Complex--Does it Exist?" Journal of International

Affairs. Vol. 26 , No. 1 (1972): pp. 1-28.

Bender, Peter. "The Superpower Squeeze." Foreign Policy. No. 65 (Winter 1986-87): pp. 98-113.

Bertram, Christoph. "The Implications of Theater Nuclear Weapons." Foreign Affairs. Vol. 60 (Winter 1981-82): pp. 305-326.

Binder, David. "Kissinger Said to Express Disgust at Allies Position." New York Times. 31 October 1973, pp. 1, 15.

"Bonn Bids U.S. Halt Arms to Israel." New York Times. 26 October 1973, p. 20.

Boulton, J.W. "NATO and the MLF." Journal of Contemporary History. Vol. 7 (July-October 1972): pp. 275-294.

Bowie, Robert R. "Strategy and the Atlantic Alliance." International Organization. Vol. 17, No. 3 (summer 1963): pp. 709-732.

"Tensions Within the Alliance." Foreign Affairs. Vol. 43, No. 1 (October 1963): pp. 49-69.

Brumley, Bryan. "U.S. Prods NATo Allies to do More." The oregonian. 29 December 1988 , p. A9.

Brzezinski, Zbigniew. "Half Past Nixon." Foreign Policy. No. 3 (Summer 1971): pp. 3-21.

Bundy, McGeorge, et al. "Nuclear Weapons and the Atlantic Alliance." Foreign Affairs. Vol. 60, No. 4 (Spring 1982) : pp. 753-768.

Burt, Richard. "The Cruise Missile and Arms Control." Survival. Vol. 18 (January/February 1976): pp. 10-17.

Calleo, David P. "American Domestic Priorities and the Demands of Alliance." Political Science Quarterly. Vol. 98, No. 1 (Spring 1983): pp. 1-15.

Canby, Steven and Dorfer, Ingemar. "More Troops, Fewer Missiles." Foreign Policy. No. 53 (Winter 1983-84): pp. 3-17.

Church, George J. "Turning on the Heat." Time. 19 September 1983, pp. 12-16. 
Colton, Timothy. "The Soviet Union under Gorbachev." Current History. Vol. 84, No. 504 (October 1985): pp. 305-308.

Dallin, Alexander and Lapidus, Gail w. "Reagan and the Russians: United States Policy toward the Soviet Union and Eastern Europe," in Oye, Kenneth A., et al, eds. Eagle Defiant: Unites States Foreign Policy in the 1980s. Boston: Little, Brown and Co., 1983, pp. 191236 .

"Soviet Foreign Policy and Domestic Politics: A Framework for Analysis," in Hoffman, Erik, and Flerow, Frederic, eds. The Conduct of Soviet Foreign Policy. Chicago: Aldine Atherton, 1971, pp. 36-49.

Dankert, Pieter. "Europe Together, America Apart."

Foreign Policy. No. 53 (Winter 1983-84): pp. 18-33.

Davis, Lynn E. "Lessons of the INF Treaty." Foreign Affairs. Vol. 66, No. 4 (Spring 1988): pp. 720-734.

Dean, Jonathan. "Military Security in Europe." Foreign Affairs. Vol. 66, No. 1 (Fall 1987): pp. 22-40.

Dougherty, James E. "European Deterrence and Atlantic Unity." ORBIS. Vol. 15 (Fall 1962): pp. 371-421.

Eichenberg, Richard. "The Myth of Hollanditis."

International Security. Vol. 8, No. 2 (Fall 1983): pp. 143-159,.

"Excerpts from the President's Address." New York Times. 18 May 1981, p. B7.

Friedberg, Aaron L. "What SALT can (and cannot) do." Foreign Policy. No. 33 (winter 1978-79): pp. 92-100.

Frye, Alton. "Strategic Build-Down." Foreign Affairs. (winter 1983-84).

Garthoff, Raymond L. "Brezhnev's Opening: The INF Tangle." Foreign Policy. No. 41 (Winter 1980-81): pp. 82-94.

"The NATO Decision on Theater Nuclear Forces." Political Science Quarterly. Vol. 98, No. 2 (Summer 1983); pp. 197-214.

Gelb, Leslie H. "U.S. Jets for Israel Took Route Around Some Allies." New York Times. 25 October 1973, pp. 1, 18 . 
Gordon, Michael R. "INF: A Hollow Victory?" Foreign Policy. No. 68 (Fall 1987): pp. 159-179.

Griffiths, Franklyn. "Cooperation as a Form of Conflict: The Soviet Approach." NATO Review. Vol. 22, No. 5 (October 1974): pp. 17-22.

Gwertzman, Bernard. "President Says U.S. Should Not Waver in Backing Saudis." New York Times. 18 October 1981, pp. 1, 15 .

"Warsaw Pact Games Arouse U.S. Concern, a Warning is Issued." New York Times. 6 March 1981, pp. A1, A4.

Hamner, Stephen R., Jr. "NATOs Long-Range Theater Forces: Modernization in Parallel with Arms Control." NATO Review. Vol. 28 (February 1980): pp. 1-6.

Hassner, Pierre. "Moscow and the Western Alliance." Problems of Communism. Vol. 30 (May-June 1981): pp. 37-54.

"Pragmatic Conservatism in the White House." Foreign Policy. No. 3 (Summer 1971): pp. 41-61.

Healy, Melissa. "NATo Chief offers Modernization Plan." The Oregonian. 11 August 1988, p. A11.

Hedlin, Myron. "Moscow's Line on Arms Control." Problems of Communism. Vol. 33 (May-June 1984): p. 19-36.

Hermann, Margaret G. "Leader Personality and Foreign Policy Behavior," in Rosenau, James N., ed. Comparing Foreign Policies. New York: Sage Publications, 1974.

Hoggard, Gary. "Differential Source Coverage in Foreign Policy Analysis," in Rosenau, James N., ed. Comparing Foreign Policies. New York: Sage Publications, 1974.

Hough, Jerry F. "Gorbachev's Strategy." Foreign Affairs. vol. 64, No. 1 (Fall 1985): pp. 33-55.

"Soviet Succession: Issues and Personalities." Problems of Communism. Vol. 31 (September-october 1982): pp. 20-40.

Howard, Michael. "NATO and the Year of Europe." Survival. (January-February 1974): pp. 21-27. 
"Reassurance and Deterrence: Western Defense in the 1980s." Foreign Affairs. Vol. 61, No. 2 (winter 1982-83): pp. 309-324.

Howorth, Jolyn. "The Third Way." Foreign Policy. No. 65 (Winter 1986-87): pp. 114-134.

Hyland, William. "Soviet Theater Forces and Arms Control Policy." Survival. (September-october 1981).

Kaiser, Robert G. "The U.S.S.R. in Decline." Foreign Affairs. Vol. 67, No. 2 (Winter 1988-89): pp. 97-113.

Keller, Bill. "Soviet tells U.N. he will make 'unilateral' troop reductions." The Oregonian. 8 December 1988 , pp. A1, A14.

Rissinger, Henry A. "NATO Defence and the soviet Threat." Survival. Vol. 21 (November-December 1979): pp. 264268 .

Kissinger, Henry A. and Vance, Cyrus. "Bipartisan Objectives for Foreign Policy." Foreign Affairs. Vol. 66, No. 5 (Summer 1988): pp. 899-921.

Korbonski, Andrzej. "Issues for Global Actors: The USSR," in Boyd, Gavin, and Pentland, Charles, eds. Issues in Global Politics. New York: The Free Press, 1981, pp. 84-117.

Kvitsinsky, Yuli. "Soviet View of Geneva." New York Times. 12 January 1984 , p. A31.

Larrabee, F. Stephen, and Lynch, Allen. "Gorbachev: The Road to Reykjavik." Eoreign Policy. No. 65 (Winter 1986-87): pp. 3-28.

Layne, Christopher. "Atlanticism Without NATO." Foreign Policy. No. 67 (Summer 1987): pp. 22-45.

Little, Richard. "A Systems Approach," in Taylor, Trevor, ed. Approaches and Theory in International Relations. London: Longman Group Limited, 1978, pp. 182-204.

Lodal, Jan M. "SALT II and American Security." Foreign Affairs. Vol. 57, No. 31 (Winter 1978-79): pp. 245268 .

Mandelbaum, Michael and Talbott, Strobe. "Reykjavik and Beyond." Foreign Affairs. Vol. 65, No. 2 (Winter 1986-87): pp. 215-235. 
McClelland, Charles and Hoggard, Gary. "Conflict Patterns in the Interactions among Nations," in Rosenau, James N., ed. International Politics and Foreign Policy.

New York: Free Press, 1969.

Moses, Lincoln E., et al. "Scaling Data on Inter-Nation Action." Science. Vol. 156, No. 3778 (May 26, 1967): pp. 1054-1059.

Naughton, James M. "Ford Says 'in time' He Expects to Talk with Nixon on China." New York Times. 2 March 1976. p. 12 .

"New Soviet Missile Reported." The Oregonian. 1 March 1984 , p. A10.

Nitze, Paul H. "Arms Control: The First Round in Geneva." The Atlantic Community Quarterly. Vo. 23, No. 1 (Spring 1985): pp. 43-50.

"The U.S. Negotiator's View of the Geneva Talks." New York Times. 19 January 1984, p. A23.

Odom, William E. "A Dissenting View on the Group Approach to Soviet Politics." World Politics. Vol. 28 (July 1976).

"Who Controls Whom in Moscow?" Foreign Policy. No. 19 (Summer 1975): pp. 109-123.

Oye, Kenneth A. "International systems structure and American Foreign Policy," in Oye, et al., eds. Eagle Defiant: United States Foreign Policy in the $1980 \mathrm{~s}$. Boston: Little, Brown and Co., 1983, pp. 3-32.

Pfaltzgraff, Robert L. "The U.S. and Europe: Partners in a Multi-Polared World?" ORBIS. Vol. 17, No. 1 (1973): pp. 31-50.

Ploss, Sidney I. "Politics in the Kremlin." Problems of Communism. Vol. 19 (May-June 1970): pp. 1-14.

Record, Jeffrey, and Rivkin, David G., Jr. "Defending PostINF Europe." Foreign Affairs. Vol. 66, No. 4 (Spring 1988): pp. 735-754.

Reese, Michael, et al. "Rethinking the Unthinkable." Newsweek. 4 April 1983, pp. 16-20. 
Roberts, Chalmers M. "The Road to Moscow," in Willrich, Mason and Rhinelander, John B., eds. SALT: The Moscow Agreements and Beyond. New York: Free Press, 1974. pp. 3-33.

Ruhe, Volker, "Geneva from a European Perspective." The Atlantic Quarterly. Vol. 23, No. 1 (Spring 1985): pp. $51-56$.

Rumer, Boris. "Structural Imbalance in the Soviet Economy." Problems of Communism. Vol. 33 (July-August 1984): pp. 24-32.

Rush, Myron. "Brezhnev and the Succession Issue." Problems of Communism. Vol. 20 (July-August 1971): pp. 9-15.

Schapiro, Leonard. "Keynote-Compromise." Problems of Communism. Vol. 20 (July-August 1971): pp. 2-8.

Schelling, Thomas C. "What Went Wrong with Arms Control?" Foreign Affairs. Vo. 64, No. 2 (Winter 1985-86): pp. 219-233.

Schlesinger, James. "Reykjavik and Revelations: A Turn of the Tide?" Eoreign Affairs. Vol. 65, No. 3 (1987): pp. $426-446$.

Schmidt, Helmut. "1977 Alstair Buchan Memorial Lecture." Survival. Vol. 20 (January-February 1978): pp. 2-10.

Schulman, Marshal1 D. "SALT and the Soviet Union," in Willrich, Mason and Rhinelander, John B., eds. SALT: The Moscow Agreements and Beyond. New York: Free Press, 1974, pp. 101-121.

Scott, Gary L., and Shinobu, Takashi. "Reassessing the Japan-China Peace and Friendship Treaty Negotiations:

A Comparative Foreign Policy Perspective." Journal of Northeast Asian Studies. Vol. II, No. 4 (December 1983): pp. 51-68.

Sharp, Jane M.O. "Arms Control and Alliance Commitments." Political Science Quarterly. Vol. 100, No. 4 (Winter 1985-86): pp. 649-667.

"Nuclear Weapons and Alliance Cohesion." Bulletin of the Atomic Scientists. No. 38 (June-July 1982): pp. 33-36.

Shuster, Alvin. "Alert Puzzles Europeans." New York Times. 27 October 1973, pp. 1, 11 . 
Simes, Dmitri K. "Are the Soviets Interested in Arms Control?" The Washington Quarterly. Vol. 8, No. 2 (Spring 1985): pp. 147-156.

"Gorbachev: A New Foreign Policy?" Foreign Affairs. Vol. 65, No. 3 (1987): pp. 477-500.

Smart, Ian. "Perspectives from Europe," in Willrich, Mason and Rhinelander, John B., eds. SALT: The Moscow Agreements and Beyond. New York: Free Press, 1974, pp. 185-208.

Smith, Jeffrey R. "Missile Deployments Roil Europe." Science. Vol. 223, No. 4637 (January 27, 1984): pp. 371-376 (Part 1 of 4 ).

"Missile Deployments Shake European Politics." Science. Vol. 223, No. 4637 (February 17, 1984): pp. 665-667 (Part 3 or 4 ).

"Missile Talks Doomed from the Start." Science. Vol. 223, No. 4636 (February 10, 1984): pp. 566-570 (Part 2 of 4 ).

"The Allure of High-Tech Weapons for Europe." Science. Vol. 223, No. 4642 (March 23, 1984): pp. 1269-1272 (Part 4 of 4 ).

Snyder, Glen H. "The Security Dilemma in Alliance Politics." World Politics. No. 36 (July 1984): pp. $461-495$.

"Soviet Subs Move into Atlantic." The Oregonian. 28 January 1984, p. A9.

Strode, Dan L., and Strode, Rebecca V. "Diplomacy and Defense in Soviet National Security Policy."

International Security. Vol. 8, No. 2 (Fall 1983): pp. 91-116.

Sulzberger, A.O., Jr. "Soviet Embarks on Blitz in U.S. of News Media." New York Times. 13 March 1981, p. A7.

The Gallup opinion Index. Princeton, N.J.; No. 79 (January 1972): p. 2; No. 85 (July 1972): p. 2; No. 95 (MaY 1973 ): pp. 1-4; No. 98 (August 1973): pp. 1-4; No. 183 (December 1980): pp. 56-57.

"Transcripts of Bush's inaugural speech." The Oregonian. 21 January 1989, p. A15. 
Treverton, Gregory F. "Nuclear Weapons and the 'Gray Area'." Foreign Affairs. Vol. 57, No. 3 (Summer 1979): pp. 1075-1089.

Ulam, Adam B. "Detente under Soviet Eyes." Foreign Policy. No. 24 (Fall 1976): pp. 145-159.

United States Department of State. The Nuclear Freeze.

Bureau of Public Affairs, Washington D.C., April 1982.

Watson, Russel, et al. "Battle over Missiles." Newsweek. 24 October 1983, pp. 36-43.

Wayman, Frank whelon. "Arms Control and Strategic Arms voting in the U.S. Senate." Journal of Conflict Resolution. Vol. 29, No. 2 (June 1985).

Wettig, Gerhard. "The Soviet INF Data Critically Reviewed." Aussen Politik. Vol. 34, No. 1 (January 1983): pp. $30-42$.

Williams, Carol J. "When Soviet troops leave, so will their nuclear arms." The Oregonian. 20 January 1989, p. A5.

Wolfe, Thomas $w$. "Soviet Approaches to SALT." Problems of Communism. Vol. 19 (September-October 1970): pp. 110 .

Yost, David S. "Soviet Ballistic Missile Defense and NATO." ORBIS. Vol. 29, No. 2 (Summer 1985): pp. 281-292.

Zlotnik, Marc D. "Chernenko succeeds." Problems of Communism. Vol. 33 (March-April 1984): pp. 17-31. 
APPENDIX 
TABLE I

SALT I SUBSYSTEM DATA

1969-MAY 1972

\begin{tabular}{ll|c|c}
\hline \multicolumn{2}{c|}{ Variable } & Observations & Percent \\
\hline US/USSR & positive & 148 & 47 \\
& neutral & 99 & 31 \\
& negative & 71 & 22 \\
\hline US/W. Europe & positive & 52 & 42 \\
& neutral & 52 & 42 \\
& negative & 20 & 16 \\
\hline W. Europe/USSR & & & \\
& positive & 89 & 14 \\
& neutral & 20 & 23 \\
\hline & negative & 32 & \\
\hline \multirow{2}{*}{ Total Observations } & 583 & \\
\hline
\end{tabular}


TABLE II

SUBSYSTEM DATA

1969

\begin{tabular}{ll|c|c}
\hline & Variable & Observations & Percent \\
\hline US/USSR & positive & 35 & 41 \\
& neutral & 33 & 39 \\
& negative & 17 & 20 \\
\hline US/W. Europe & positive & 24 & 43 \\
& neutral & 22 & 39 \\
& negative & 10 & 18 \\
& & & \\
\hline N. Europe/USSR & & & 60 \\
& positive & 29 & 17 \\
& neutral & 8 & 23 \\
\hline & negative & 11 & \\
\hline \multirow{2}{*}{ Total Observations } & 189 & \\
\hline
\end{tabular}


TABIE III

SUBSYSTEM DATA

1970

\begin{tabular}{ll|c|c}
\hline & Variable & Observations & Percent \\
\hline US/USSR & positive & & \\
& neutral & 21 & 32 \\
& negative & 17 & 26 \\
& positive & 28 & 42 \\
\hline US/W. Europe & neutral & 4 & 23.5 \\
& negative & 9 & 53 \\
& & 4 & 23.5 \\
\hline N. Europe/USSR & positive & 15 & 19 \\
& neutral & 4 & 10 \\
\hline
\end{tabular}


TABLE IV

SUBSYSTEM DATA

1971

\begin{tabular}{ll|c|c}
\hline \multicolumn{2}{c|}{ Variable } & Observations & Percent \\
\hline US/USSR & positive & 58 & 59 \\
& neutral & 27 & 28 \\
& negative & 13 & 13 \\
\hline US/N. Europe & positive & 15 & 55 \\
& neutral & 8 & 30 \\
& negative & 4 & 15 \\
\hline \multirow{2}{*}{ N. Europe/USSR } & positive & 28 & 64 \\
& neutral & 2 & 4 \\
& negative & 14 & 32 \\
\hline \multirow{2}{*}{ Total Observations } & 169 & \\
\hline
\end{tabular}


TABLE V

SUBSYSTEM DATA

THRU MAY 1972

\begin{tabular}{ll|c|c}
\hline \multicolumn{2}{c|}{ Variable } & Observations & Percent \\
\hline US/USSR & positive & 34 & 49 \\
& neutral & 22 & 32 \\
& negative & 13 & 19 \\
\hline US/W. Europe & positive & 9 & 38 \\
& neutral & 13 & 54 \\
& negative & 2 & 8 \\
\hline W. Europe/USSR & positive & 17 & 61 \\
& neutral & 6 & 21 \\
& negative & 5 & 18 \\
\hline
\end{tabular}


TABLE VI

SALT II SUBSYSTEM DATA

1973-1979

\begin{tabular}{ll|c|c}
\hline \multicolumn{2}{c|}{ Variable } & Observations & Percent \\
\hline US/USSR & positive & 229 & 41 \\
& neutral & 185 & 33 \\
& negative & 146 & 26 \\
\hline US/W. Europe & & 133 & 39 \\
& positive & 138 & 41 \\
& neutral & 69 & 20 \\
\hline n. Europe/USSR & positive & 94 & 47 \\
& neutral & 50 & 25 \\
& negative & 57 & 28 \\
\hline \multirow{2}{*}{ Total Observations } & 1101 & \\
\hline
\end{tabular}


TABLE VII

SUBSYSTEM DATA

1973

\begin{tabular}{ll|c|c}
\hline \multicolumn{2}{c|}{ Variable } & Observations & Percent \\
\hline US/USSR & positive & 47 & 47 \\
& neutral & 37 & 37 \\
& negative & 16 & 16 \\
\hline US/W. Europe & & & \\
& positive & 19 & 30 \\
& neutral & 27 & 43 \\
& negative & 17 & 27 \\
\hline W. Europe/USSR & & 30 & 65 \\
& positive & 7 & 15 \\
& neutral & 9 & 20 \\
\hline & negative & 209 & \\
\hline \multirow{2}{*}{ Total Observations } & & \\
\hline
\end{tabular}


TABLE VIII

SUBSYSTEM DATA

1974

\begin{tabular}{ll|c|c}
\hline \multicolumn{2}{c|}{ Variable } & Observations & Percent \\
\hline US/USSR & positive & 73 & 53.5 \\
& neutral & 43 & 31.5 \\
& negative & 20 & 15 \\
\hline US/N. Europe & & & 42 \\
& positive & 21 & 42 \\
& neutral & 21 & 16 \\
& negative & 8 & 61 \\
& & 19 & 16 \\
W. Europe/USSR & positive & 5 & 23 \\
& neutral & 7 & \\
\hline & negative & 217 & \\
\hline
\end{tabular}


TABLE IX

SUBSYSTEM DATA

1975

\begin{tabular}{ll|c|l}
\hline \multicolumn{2}{c|}{ Variable } & Observations & Percent \\
\hline US/USSR & positive & 26 & 41 \\
& neutral & 22 & 35 \\
& negative & 15 & 24 \\
\hline US/W. Europe & positive & 20 & 34 \\
& neutral & 23 & 39 \\
& negative & 16 & 27 \\
\hline \multirow{2}{*}{ W. Europe/USSR } & positive & 15 & 52 \\
& neutral & 9 & 31 \\
& negative & 5 & 17 \\
\hline \multirow{2}{*}{ Total Observations } & 151 & \\
\hline
\end{tabular}


TABLE X

SUBSYSTEM DATA

1976

\begin{tabular}{ll|c|c}
\hline \multicolumn{2}{c|}{ Variable } & Observations & Percent \\
\hline US/USSR & positive & 17 & 31 \\
& neutral & 22 & 41 \\
& negative & 15 & 28 \\
\hline US/W. Europe & positive & 14 & 42.5 \\
& neutral & 14 & 42.5 \\
& negative & 5 & 15 \\
\hline \multirow{2}{*}{ W. Europe/USSR } & positive & 5 & 28 \\
& neutral & 6 & 33 \\
& negative & 7 & 39 \\
\hline Total Observations & 105 & \\
\hline
\end{tabular}


TABLE XI

SUBSYSTEM DATA

1977

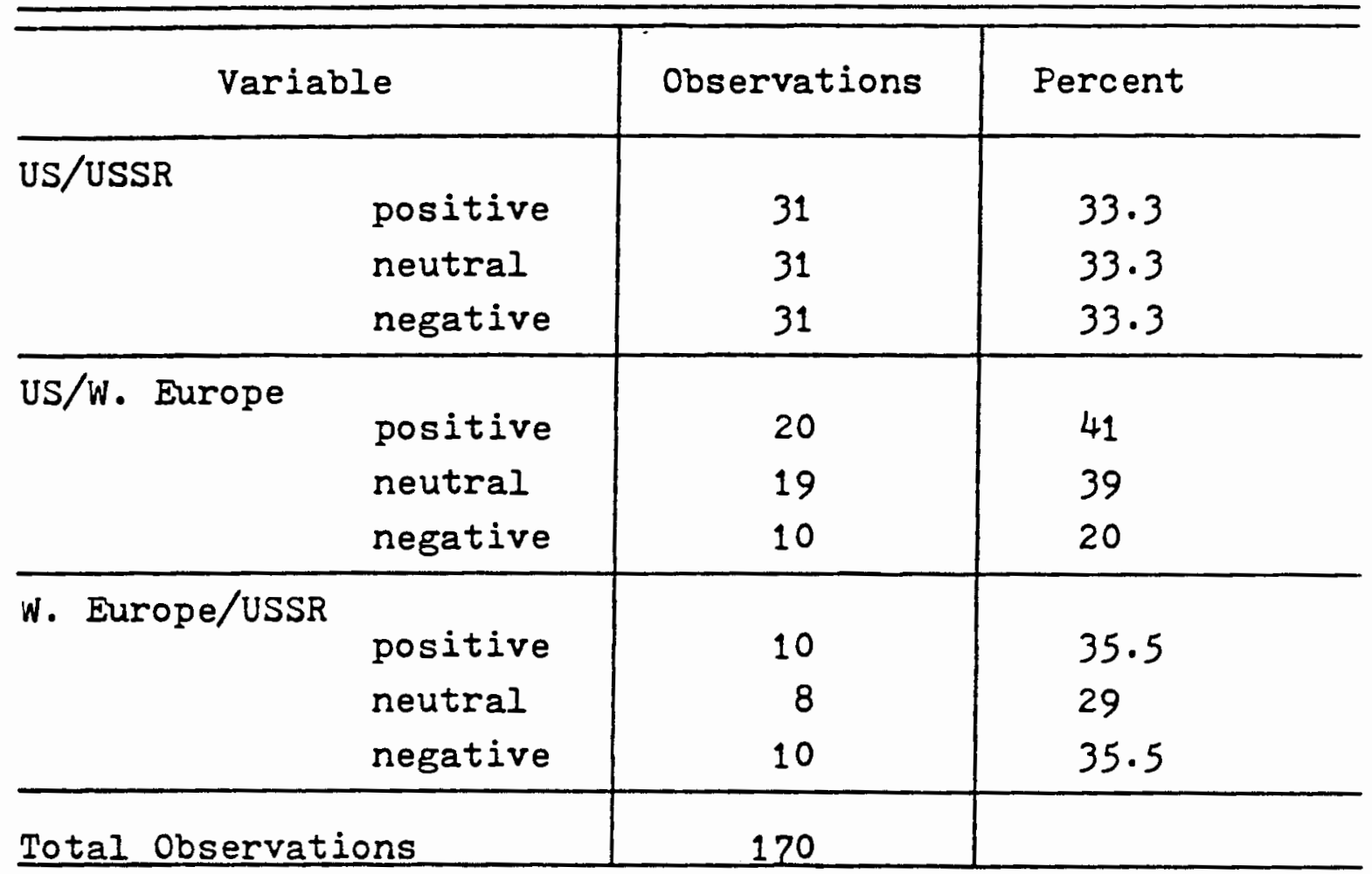


TABIE XII

SUBSYSTEM DATA

1978

\begin{tabular}{ll|c|c}
\hline \multicolumn{2}{c|}{ Variable } & Observations & Percent \\
\hline US/USSR & positive & 20 & 29 \\
& neutral & 16 & 24 \\
& negative & 32 & 47 \\
\hline US/N. Europe & positive & 24 & 46 \\
& neutral & 20 & 39 \\
& negative & 8 & 15 \\
\hline W. Europe/USSR & positive & 8 & 32 \\
& neutral & 9 & 36 \\
& negative & 8 & 32 \\
\hline Total Observations & 145 & \\
\hline
\end{tabular}


TABLE XIII

SUBSYSTEM DATA

1979

\begin{tabular}{ll|c|c}
\hline \multicolumn{2}{c|}{ Variable } & Observations & Percent \\
\hline US/USSR & positive & 15 & 33 \\
& neutral & 14 & 30 \\
& negative & 17 & 37 \\
\hline US/W. Europe & positive & 15 & 44 \\
& neutral & 14 & 41 \\
& negative & 5 & 15 \\
\hline W. Europe/USSR & positive & 7 & 29 \\
& neutral & 6 & 25 \\
& negative & 11 & 46 \\
\hline \multirow{2}{*}{ Total Observations } & 104 & \\
\hline
\end{tabular}


TABLE XIV

INP/START SUBSYSTEM DATA

1980-1983

\begin{tabular}{ll|c|c}
\hline \multicolumn{2}{c|}{ Variable } & Observations & Percent \\
\hline US/USSR & positive & 55 & 18.3 \\
& neutral & 94 & 31.3 \\
& negative & 151 & 50.3 \\
\hline US/W. Europe & & 66 & 32 \\
& positive & 92 & 45 \\
& neutral & 47 & 23 \\
\hline & negative & 24 & 19.5 \\
& & 45 & 36.5 \\
W. Europe/USSR & positive & 54 & 44 \\
& neutral & 628 & \\
\hline
\end{tabular}


TABLE XV

SUBSYSTEM DATA

1980

\begin{tabular}{ll|c|c}
\hline \multicolumn{2}{c|}{ Variable } & Observations & Percent \\
\hline US/USSR & positive & 8 & 11 \\
& neutral & 24 & 33 \\
& negative & 40 & 56 \\
\hline US/W. Europe & positive & 20 & 38 \\
& neutral & 21 & 40 \\
& negative & 12 & 22 \\
\hline W. Europe/USSR & & 6 & 21 \\
& positive & 15 & 52 \\
& neutral & 8 & 27 \\
\hline Total Observations & negative & 154 & \\
\hline
\end{tabular}


TABIE XVI

SUBSYSTEM DATA

1981

\begin{tabular}{ll|c|c}
\hline \multicolumn{2}{c|}{ Variable } & Observations & Percent \\
\hline US/USSR & positive & 14 & 19 \\
& neutral & 23 & 31 \\
& negative & 37 & 50 \\
\hline US/W. Europe & positive & 15 & 29 \\
& neutral & 23 & 44 \\
& negative & 14 & 27 \\
\hline W. Europe/USSR & & & 17.5 \\
& positive & 4 & 30.5 \\
& neutral & 7 & 52 \\
\hline
\end{tabular}


TABLE XVII

SUBSYSTEM DATA

1982

\begin{tabular}{ll|c|c}
\hline \multicolumn{2}{c|}{ Variable } & Observations & Percent \\
\hline US/USSR & positive & 17 & 28 \\
& neutral & 18 & 29.5 \\
& negative & 26 & 42.5 \\
\hline US/W. Europe & positive & 16 & 31 \\
& neutral & 28 & 55 \\
& negative & 7 & 14 \\
\hline W. Europe/USSR & positive & 4 & 16 \\
& neutral & 6 & 24 \\
& negative & 15 & 60 \\
\hline Total Observations & 137 & \\
\hline
\end{tabular}


TABLE XVIII

SUBSYSTEM DATA

1983

\begin{tabular}{ll|c|c}
\hline \multicolumn{2}{c|}{ Variable } & Observations & Percent \\
\hline US/USSR & positive & 16 & 17 \\
& neutral & 29 & 31 \\
& negative & 48 & 52 \\
\hline US/W. Europe & & & \\
& positive & 15 & 30.5 \\
& neutral & 20 & 41 \\
& negative & 14 & 28.5 \\
\hline W. Europe/UsSR & & 10 & 22 \\
& positive & 17 & 37 \\
& neutral & 19 & 41 \\
\hline & negative & 188 & \\
\hline
\end{tabular}

